\title{
Review Article \\ Adipose-Derived Stem Cells in Tissue Regeneration: A Review
}

\author{
Patricia Zuk \\ Regenerative Bioengineering and Repair Laboratory and Division of Plastic and Reconstructive Surgery, Department of Surgery, \\ David Geffen School of Medicine at UCLA, Los Angeles, CA 90095, USA \\ Correspondence should be addressed to Patricia Zuk; pzuk@mednet.ucla.edu
}

Received 30 September 2012; Accepted 23 October 2012

Academic Editors: A. Chapel and S. M. Hwang

Copyright (C) 2013 Patricia Zuk. This is an open access article distributed under the Creative Commons Attribution License, which permits unrestricted use, distribution, and reproduction in any medium, provided the original work is properly cited.

In 2001, researchers at the University of California, Los Angeles, described the isolation of a new population of adult stem cells from liposuctioned adipose tissue. These stem cells, now known as adipose-derived stem cells or ADSCs, have gone on to become one of the most popular adult stem cells populations in the fields of stem cell research and regenerative medicine. As of today, thousands of research and clinical articles have been published using ASCs, describing their possible pluripotency in vitro, their uses in regenerative animal models, and their application to the clinic. This paper outlines the progress made in the ASC field since their initial description in 2001, describing their mesodermal, ectodermal, and endodermal potentials both in vitro and in vivo, their use in mediating inflammation and vascularization during tissue regeneration, and their potential for reprogramming into induced pluripotent cells.

\section{The ASC}

In 2001, Zuk and colleagues at the David Geffen School of Medicine at UCLA identified and described a putative population of multipotent stem cells that they termed Processed Lipoaspirate Cells or PLA cells [1]. These cells, initially characterized in the journal Tissue Engineering, were named as such due to their derivation from processed lipoaspirate tissue obtained through cosmetic surgery. Zuk et al. based their isolation method for these PLA cells on existing enzymatic strategies for the isolation of the stromal vascular fraction (SVF) from adipose tissue. The SVF has been defined as a minimally processed population of red blood cells, fibroblasts, endothelial cells, smooth muscle cells, pericytes, and preadipocytes that have yet to adhere to a tissue culture substrate [2,3]. Culturing of this SVF over time thought to eliminate many of these cell populations, resulting in an adherent population primarily composed of preadipocytes. However, Zuk et al. suggested, through histology and preliminary PCR analysis, that the adherent population derived from the SVF contains a significant number of cells that display characteristics of a multipotent stem cell. Specifically, Zuk et al. proposed that the culturing of the SVF results in a relatively homogenous population of PLA cells, free of contaminating cell populations, and capable of displaying phenotypic characteristics of adipocytes, osteoblasts, and chondrocytes [1]. Moreover, this article also showed that clonal cell populations derived from single PLA-derived could also be differentiated into the cell types-an important prerequisite along the path to identifying a stem cell.

Since this study, thousands of articles have been published on PLA cells using a variety of terminology, including adipose-derived stem cells (ADSCs), adipose-derived adult stem (ADAS) cells, adipose-derived mesenchymal stem cells (AD-MSCs), adipose MSCs (AMSCs), and adipose stro$\mathrm{mal} / \mathrm{stem}$ cells (ASCs). In an attempt to ameliorate some of the confusion, the 2nd annual IFATS conference proposed that researchers using the PLA cell should come to some sort of consensus with regards to their terminology. The International Society for Cellular Therapy has suggested that plastic-adherent cells derived from mesenchymal tissues and showing multipotency should be termed mesenchymal stromal cells, regardless of their tissue source, while the term stem cell should be used to describe a subset of cells showing definitive stem cell characteristics, including (1) adherence to tissue culture plastic; (2) multipotency and the maintenance of multipotency upon in vitro expansion; and (3) self-renewal capacity over the long term [4]. Despite the absence of data confirming the last qualification, the IFATs conference determined that the term ASC, or Adipose-derived Stem 


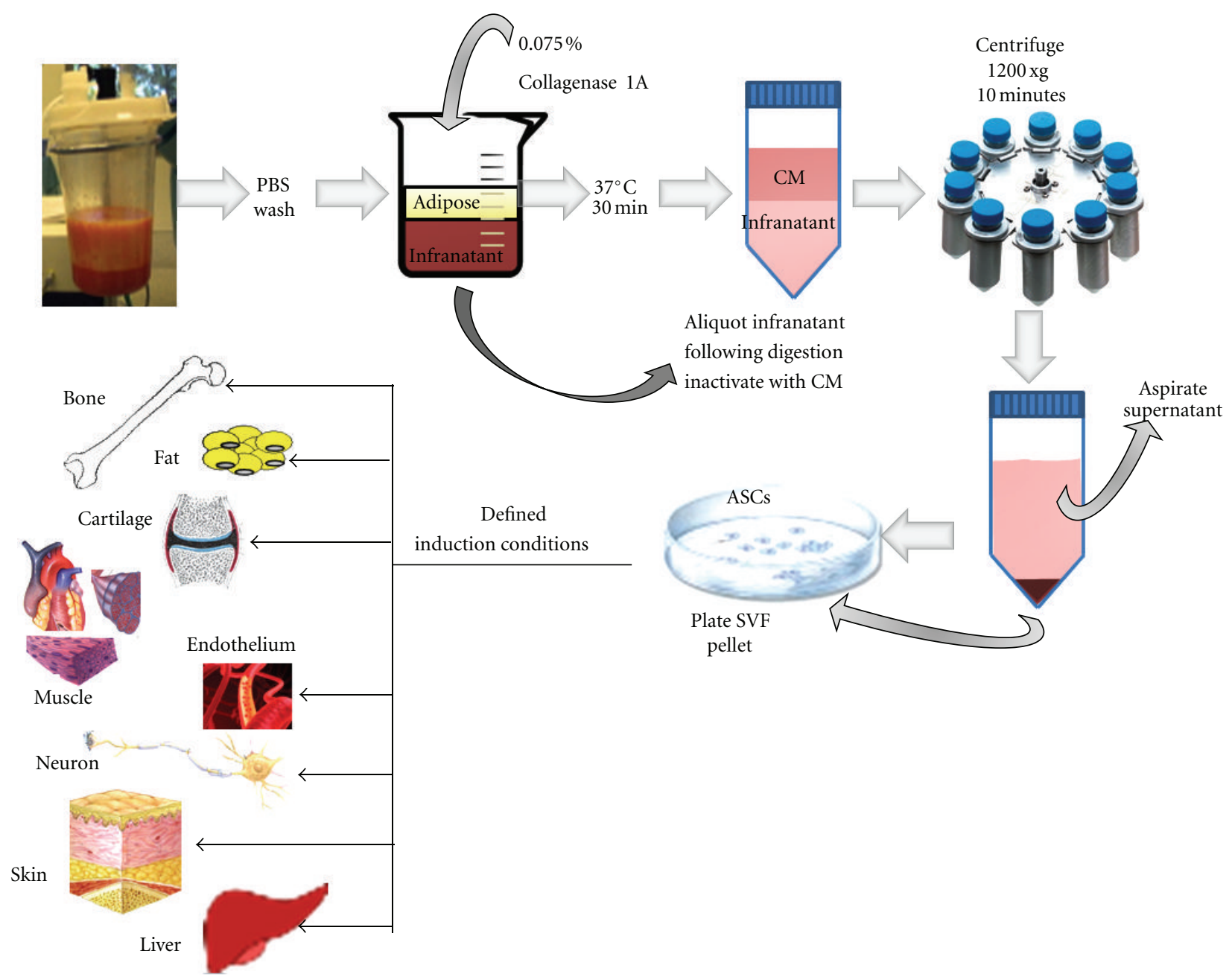

FIGURE 1: ASC isolation and utilization. Schematic outline of the isolation of ASCs from lipoaspirates showing the enzymatic digestion of adipose tissue with collagenase type IA and the isolation of the SVF via centrifugation. Plating of the SVF results in eventual selection and expansion of the ASC population. Induction of ASCs under defined conditions can result in their differentiation to multiple cell types of the mesodermal (bone, fat, cartilage, muscle types), ectodermal (endothelium, neurons, epidermis/skin), and endodermal (liver) lineages.

Cell, would be used to refer to plastic-adherent, cultured multipotent stromal cells isolated from the SVF. A schematic summary of ASC isolation and their potentials is shown in Figure 1. While many researchers still continue to use their own designation, this review article will conform to the IFATS designation.

The original article on PLA cells/ASCs resulted in a significant paradigm shift in the field of adult stem cells. While the presence of stem cells has been postulated since the late 1990s in nearly every adult tissue $[5,6]$, the gold-standard of adult mesenchymal stem cells has been the bone marrow MSC. Since its initial identification by Friedenstein et al. in 1968, the MSC has dominated much of the literature describing the use of adult stem cells in regenerative medicine [7]. Initially described as possessing multipotent mesodermal potential both in vitro and in vivo, the potential of the MSC has been expanded with subsequent articles suggesting ectodermal and endodermal potentials (reviewed in $[8,9]$ ). Such trigerm layer potentials could make the MSC an excellent stem cell choice for a wide variety of translational applications and eventual transition into the clinic. However, one could argue that this clinical use might be limited for several reasons. First, there is a stigma associated with a bone marrow harvest as the harvest is considered a relatively painful procedure. Second, the bone marrow harvest may actually yield very few stem cells. While bone marrow aspirates yield on average $6 \times$ $10^{6}$ nucleated cells per $\mathrm{mL}$, only 0.001 to $0.01 \%$ are thought to be stem cells [10]. As a response to these drawbacks, the ASC has been suggested as an alternative stem cell population. While there is pain associated with the cosmetic procedures used to obtain fat, most would consider the pain of the adipose tissue harvest to be an acceptable "tradeoff" in light of the positive aesthetic effects liposuction or lipoplasty provide. Moreover, in comparison to bone marrow, an adipose tissue harvest yields significantly more stem cells. Indeed, as source of regenerative stem cells, adipose tissue may have no equal. Recent studies have documented that 1 gram of adipose tissue can yield approximately $2 \times 10^{6}$ cells, 
TABLE 1: Cell surface expression profiles of human ASCs.

\begin{tabular}{|c|c|c|c|}
\hline \multirow{2}{*}{ Author and Year } & \multirow{2}{*}{ Reference } & \multicolumn{2}{|c|}{ Expression profile } \\
\hline & & Positive expression & Negative expression \\
\hline Gronthos et al. 2001 & {$[15]$} & $\begin{array}{l}\text { CD9, CD10, CD13, CD29, CD34, CD44, } \\
\text { CD49d, CD49e, CD54, CD55, CD59, } \\
\text { CD105, CD146, CD166, HLA-ABC }\end{array}$ & $\begin{array}{l}\text { CD11a, CD11b, CD11c, CD31, } \\
\text { CD45, CD50, CD56, CD62e, } \\
\text { HLA-DR }\end{array}$ \\
\hline Zuk et al. 2001 & {$[1]$} & CD13, CD29, CD44, CD49d, CD71, & CD14,CD16, CD31,CD34, CD45, \\
\hline Zuk et al. 2002 & {$[21]$} & CD90, CD105, STRO-1, SH3 & CD56, CD62e, CD104, CD106, SMA \\
\hline Katz et al. 2005 & {$[20]$} & $\begin{array}{l}\text { CD29, CD49b, CD49d, CD49e, CD } 51 \text {, } \\
\text { CD61, CD90, CD138, CD140a }\end{array}$ & $\begin{array}{l}\text { CD11a, CD11b, CD11c, CD18, } \\
\text { CD41a, CD49f, CD62L, CD62P, } \\
\text { CD106, CD117, CD133, HLA-DR, ABCG2 }\end{array}$ \\
\hline Mitchell et al. 2006 & {$[16]$} & $\begin{array}{l}\text { CD13, CD29, CD34, CD44, CD49a, } \\
\text { CD63, CD73, CD90, CD146, CD166 }\end{array}$ & CD31, CD144 \\
\hline Yoshimura et al. 2006 & {$[17]$} & CD34, CD90 & CD31, CD45, CD105, CD146 \\
\hline $\begin{array}{l}\text { Oedayrajsingh-Varma et } \\
\text { al. } 2007\end{array}$ & {$[18]$} & $\begin{array}{l}\text { CD34, CD54, CD90, CD105, CD117, } \\
\text { HLA-ABC, HLA-DR }\end{array}$ & $\begin{array}{l}\text { CD31, CD45, CD106, CD146, } \\
\text { CD166 }\end{array}$ \\
\hline Zannettino et al. 2008 & {$[19]$} & $\begin{array}{l}\text { CD44, CD90, CD105, CD106, } \\
\text { CD146, CD166, STRO-1, 3G5 }\end{array}$ & CD14, CD31, CD45 \\
\hline Traktuev et al. 2008 & {$[27]$} & $\begin{array}{l}\text { CD10, CD13, CD34, CD90, CD140a, } \\
\text { CD140b, SMA }\end{array}$ & CD31, CD45, CD144 \\
\hline Zimmerlin et al. 2010 & {$[26]$} & CD34, CD90 & CD31, CD146, SMA \\
\hline Lin et al. 2008 & [25] & CD34 & CD31, CD140b, SMA \\
\hline $\begin{array}{r}\text { Proposed phenoty } \\
\text { (common between two }\end{array}$ & $\begin{array}{l}\text { of ASCS } \\
\text { more studies) }\end{array}$ & $\begin{array}{l}\text { CD13, CD29, CD34, CD44, CD49d, } \\
\text { CD54, CD90, CD140a, } \\
\text { HLA-ABC }\end{array}$ & $\begin{array}{l}\text { CD11a, CD11b, CD11c, CD14, } \\
\text { CD31, CD45, CD106, CD144 }\end{array}$ \\
\hline Controversial mark & s in ASCs & $\begin{array}{l}\text { CD105, CD140b, CD146, CD166, } \\
\text { SMA, HLA-DR }\end{array}$ & \\
\hline Stromal cell $\mathrm{m}$ & kers & CD29, CD44, CD73, CD90, CD166 & \\
\hline Hematopoietic & arkers & CD31, CD34, CD45, ABCG2 & \\
\hline Pericyte ma & & CD146, Stro-1, 3G5 & \\
\hline
\end{tabular}

Markers in common between studies shown in bold.

SMA: smooth muscle actin.

HLA: human leukocyte antigen.

ABCG2: multidrug transporter protein G2.

3G5: pericyte marker.

with $10 \%$ of these cells thought to be ASCs [11-13]. Recent work directly comparing ASCs and MSCs has measured tenfold more CFU-F units following an ASC harvest [14]. As such, the ASC may be a more suitable stem cell than the MSC for eventual clinical application. However, clinical use of the ASC first requires extensive characterization both in vitro and in vivo to ensure that the cells are multipotent.

\section{The First Few Years: In Vitro Characterization of the ASC}

2.1. The ASC CD Profile and Niche. The first ASC article published in Tissue Engineering has since been followed by over 3000 articles available through PubMed. The earliest of these articles detailed a basic in vitro characterization of the ASC in the hopes of identifying a unique CD "signature" that could be ascribed specifically to the ASC. For this Gronthos et al. [15] examined the expression of cell surface CD antigens. Subsequent articles have since continued this work and are summarized in Table 1. While some minor differences in this profile have been described from research group to group, there is a general consensus among these characterization articles that the ASC is positive for CD13, CD29, CD44, CD49d, CD90, and CD105, and negative for the majority of hematopoeitic antigens such as CD14, CD31, CD45, and CD144 [16-21]. The expression of CD29, CD44, and CD90 is consistent with cells of mesodermal/stromal original and their expression on the ASC is not surprising, leading many to classify the ASC as a stromal stem cell based on the expression of these markers. Additional research has refined this profile to suggest that the ASC is specifically $\mathrm{CD} 34^{+}$ and $\mathrm{CD} 31^{-} / \mathrm{CD} 45^{-}$, with groups isolating this subset of cells and specifically observing their multipotent differentiation $[17,18,22]$. In vivo transplantation experiments using lipodystrophic mouse models and lineage tracing studies suggest that the ASC population within the SVF is a $\mathrm{Lin}^{-}$, $\mathrm{CD} 29^{+} / \mathrm{CD} 34^{+} / \mathrm{Sca}-1^{+}$population $[23,24]$.

Stem cells reside in a specialized environment known as a niche that can control many aspects of the stem cells' behavior including proliferation, differentiation, and apoptosis (jones 
and wagers 2008). Several recent studies have suggested that the niche for the ASC is the vasculature of adipose tissue [25-27]. Zimmerlin et al. 2010 have gone so far as to identify the ASC as a supra-adventitial ASC, located in the outer adventitial ring of the vasculature. The migration of ASCs to areas surrounding blood vessels after reinjection into adipose tissue supports this theory [28]. Recently, the expression of CD146 by ASCs, together with the expression of 3G5-a pericyte marker, has led others to suggest that the ASC may actually be a pericyte located within the adipose vasculature $[19,29]$. To investigate this further, Tang et al. 2008 describe a system for maintaining the stromal vascular structure within adipose tissue so that the niche is preserved [23]. In this study, they claim to localize ASCs expressing pericyte markers arrayed around blood vessels. Pericytes have been described as possessing multipotency similar to stem cells $[19,30]$. Since adipose tissue is a highly vascularized tissue that would yield a good supply of pericytes upon harvest, this hypothesis may have merit. Moreover, adipogenesis and angiogenesis are known to be intimately linked [31]. However, there still remains disagreement as to whether the ASC expresses CD146, making it difficult to conclude that ASCs and pericytes are one in the same. In addition, the absence of smooth muscle actin/SMA (a pericyte marker) in the majority of isolated ASC populations might also argue against its classification as a pericyte. Whether these differences are due to isolation and/or expansion techniques remains unknown. However, a 2009 review by Zeve et al. 2009 suggests that the SVF of adipose tissue might be a source for several stem cell populations-an endothelial precursor population, a supraadventitial ASC population, and a pericyte population [32]. Each population, while sharing many $\mathrm{CD}$ markers, shows distinct differences in the expression of CD146 and SMA (in the pericyte population only). Added to this, a recent study suggests that a population of smooth muscle cells may be isolated through adherence from fresh SVF pellets, with a phenotypic profile distinct from the ASC population [33]. Therefore, it is possible that the discrepancies observed with regards to these markers may be due to the isolation and expansion of distinct cellular subsets from the SVF and that the $\mathrm{CD} 146^{+}$ASC populations isolated by Lin et al. 2008, Traktuev et al. 2008 and Zimmerlin et al. 2010 are not the same as those isolated by Yoshimura et al. 2006 or Oedayrajsingh-Varma et al. 2007. So while the origin of the ASC is an interesting intellectual exercise, from a translational or clinical perspective, knowing that multipotent stem cells like the ASC can be isolated from adipose tissue and used for the benefit of the patient may be more important.

One cell surface marker that has received significant attention in the stem cell field is the HLA class of cell surface antigens. Divided into classes such as HLA (or MHC) class I (i.e., HLA-A, B, and C) and HLA (or MHC) class II (i.e., HLA-DP, DM, and DR), HLA receptors display proteins on the cell surface for immune surveillance. Of particular interest is the HLA/MHC class II protein, which is found on the surface of antigen-presenting cells and plays critical roles in immunotolerance and transplantation (for reviews see $[34,35])$. Immunophenotyping of ASCs has confirmed the absence of the HLA-class II antigen on the ASC surface and the absence of this HLA protein may allow the ASC to evade the host's immune surveillance machinery. This may make it possible to use ASCs in xenogeneic model systems of tissue regeneration. An excellent review of these models can be found in a recent article by Lin et al. 2012 [36] and will not be discussed in this chapter. However, the general consensus from these studies is that the ASC is capable of evading the host's immune system. Of additional interest is a recent study by DelaRosa et al. 2012 [37], who note that human ASCs have lower susceptibility to natural killer (NK) cellmediated lysis in comparison to bone marrow MSCs. This finding may be part of the reason for xenogeneic tolerance of ASCs in that NK-ASC crosstalk does not result in immediate recognition of foreign cells. Continued research in this area is sure to expand the possible uses of ASCs in translational model systems.

2.2. The Mesodermal Potential of ASCs: In Vitro Bone, Fat, and Cartilage Potentials. In 2002, Zuk and colleagues expanded upon their initial characterization of the ASC with a more in-depth molecular analysis in the journal Molecular Biology of the Cell [21]. Specifically, the osteogenic, adipogenic, and chondrogenic potentials of ASCs were confirmed using a combination of immunofluorescence, PCR analysis and functional assay for bone, cartilage, and fat formation. In support of their work, the tri-lineage mesodermal potential of human ASCs has since been confirmed in a series of in vitro articles using a variety of induction conditions (Table 2), including dexamethasone [38, 39], (VD3) [40], hypoxia [41, 42], numerous growth factors and hormones [43-48], mechanical stress [49-51], and even scaffolding materials such as akermanite [52] and amorphous calcium phosphate nanoparticles [53]. Osteogenesis by human ASCs has also been reported under 3D culture on a wide variety of scaffolds such as collagen [54], PLGA [55, 56], tricalcium phosphate substrates [57], sintered matrices [58], multiwalled carbon nanotubes [59], silk sponges [60], bioactive glass [61], and polycaprolactone [62]. ASC-derived osteogenic precursors from both murine and rat adipose tissues, together with other animals such as rabbits, dogs, horses, rhesus monkey, and even brown bear, have also been described [63-68]. Most recently, the isolation of ASCs from human cadaveric adipose tissue and their adherence and survival on demineralized bone allografts has been reported [69], suggesting that viable ASCs for osteogenic differentiation may also be obtained from cadavers within 24 hours of their death. Using in vitro culture systems, the expression patterns of key osteogenic genes have been assessed using livecell, temporal gene expression analysis of ASC osteogenesis under dexamethasone/VD3 induction [70], and numerous studies characterize the role of key signaling pathways in this lineage [71-78]. Recent studies have expanded upon this work to identify the role of miRNA in this lineage, identifying putative roles for miRNAs such as miR-22, miR-17, miR-637, and miR-196a in osteogenesis [79-82]. In addition to osteogenesis, the chondrogenic potential of human and rodent ASCs under high-density monolayer or pellet culture, in combination with TGF $\beta 1$ or TGF $\beta 2$, has been described by many $[63,66,83,84]$. In vitro chondrogenesis has also 
TABLE 2: In vitro differentiation potentials of ASCs.

\begin{tabular}{|c|c|c|c|c|}
\hline Germ layer & Lineage & Author and year & Reference & Induction conditions \\
\hline \multirow{37}{*}{ Mesoderm } & \multirow{8}{*}{ Bone-2D } & Zuk et al. 2002 & {$[21]$} & Dexamethasone induction \\
\hline & & Leong et al. 2006 & {$[40]$} & Vitamin D3 induction \\
\hline & & Behr et al. 2011 & {$[43]$} & VEGF supplementation \\
\hline & & Hong et al. 2007 & {$[44]$} & $17 \beta$-estradiol supplementation \\
\hline & & Knippenberg et al. 2007 & {$[45]$} & Prostaglandin supplementation \\
\hline & & Park et al. 2011 & {$[46]$} & Growth factor-coupled microspheres \\
\hline & & Song et al. 2011 & {$[47]$} & BMP2 + vitamin D3 induction \\
\hline & & Chen et al. 2012 & {$[48]$} & BMP2 + platelet-rich plasma \\
\hline & \multirow{9}{*}{ Cartilage-2D } & Hao et al. 2008 & {$[55]$} & \multirow{2}{*}{ PLGA scaffolds } \\
\hline & & Lee et al. 2008 & {$[56]$} & \\
\hline & & Marino et al. 2010 & {$[57]$} & Tricalcium phosphate scaffolds \\
\hline & & Haimi et al. 2009 & {$[61]$} & PLA/Bioactive glass scaffolds \\
\hline & & Leong et al. 2008 & {$[62]$} & PCL scaffolds \\
\hline & & Zuk et al. 2002 & {$[21]$} & \multirow{2}{*}{ Micromass culture + TGF $\beta 1$} \\
\hline & & Awad et al. 2003 & {$[84]$} & \\
\hline & & Ogawa et al. 2004 & {$[66]$} & $\begin{array}{l}\text { Micromass culture + TGF } \beta 1-G F P+v e \\
\text { mice }\end{array}$ \\
\hline & & Jin et al. 2007 & {$[85]$} & $\begin{array}{l}\text { Micromass culture + TGF } \beta 2 \text {-expressing } \\
\text { ASCs }\end{array}$ \\
\hline & \multirow{4}{*}{ Cartilage-3D } & Lu et al. 2012 & {$[86]$} & $\begin{array}{l}\text { Micromass culture }+ \text { TGF } \beta 3 \text {-expressing } \\
\text { ASCs }\end{array}$ \\
\hline & & Awad et al. 2004 & {$[88]$} & Agarose, alginate and gelatin scaffolds \\
\hline & & Lin et al. 2005 & {$[89]$} & Alginate scaffolds \\
\hline & & Yoon et al. 2011 & {$[91]$} & Hyaluronate scaffolds \\
\hline & \multirow{2}{*}{ Adipose } & Zuk et al. 2002 & {$[21]$} & $\begin{array}{l}\text { Dexamethasone, insulin, IBMX, } \\
\text { indomethacin }\end{array}$ \\
\hline & & Ogawa et al. 2004 & {$[95]$} & GFP+ve mice \\
\hline & \multirow{5}{*}{ Skeletal muscle } & Rodriguez et al. 2004 & {$[96]$} & $\begin{array}{l}\text { Serum-free adipogenic medium + } \\
\text { rosiglitazone }\end{array}$ \\
\hline & & Mizuno et al. 2002 & {$[98]$} & $\begin{array}{l}\text { Reduced serum, hydrocortisone } \\
\text { induction }\end{array}$ \\
\hline & & Lee and Kemp 2006 & {$[99]$} & $\begin{array}{l}\text { ASC/myoblast co-culture, hypoxic } \\
\text { conditions }\end{array}$ \\
\hline & & Eom et al. 2011 & {$[100]$} & Myoblast fusion \\
\hline & & Choi et al. 2012 & {$[101]$} & Mechanically patterned hydrogels \\
\hline & \multirow{5}{*}{ Smooth muscle } & Rodriguez et al. 2006 & {$[102]$} & Heparin induction medium \\
\hline & & Wang et al. 2010 & {$[103]$} & TGF $\beta 1+$ BMP4 induction \\
\hline & & Park et al. (In press) & {$[108]$} & Elastic nanofibers + stress \\
\hline & & Harris et al. 2011 & {$[105]$} & Decellularized vascular grafts \\
\hline & & Wang et al. 2010 & {$[109]$} & PGA mesh + pulsatile conditions \\
\hline & \multirow{4}{*}{ Cardiac muscle } & Planat-Bénard et al. 2004 & {$[115]$} & 5-azacytidine induction \\
\hline & & Gaustad et al. 2004 & {$[114]$} & Cardiomyocyte cellular extracts \\
\hline & & Choi et al. 2010 & {$[118]$} & Cardiomyocyte/ASC co-culture \\
\hline & & Chang et al. 2012 & {$[119]$} & PMA treatment \\
\hline
\end{tabular}


TABLe 2: Continued.

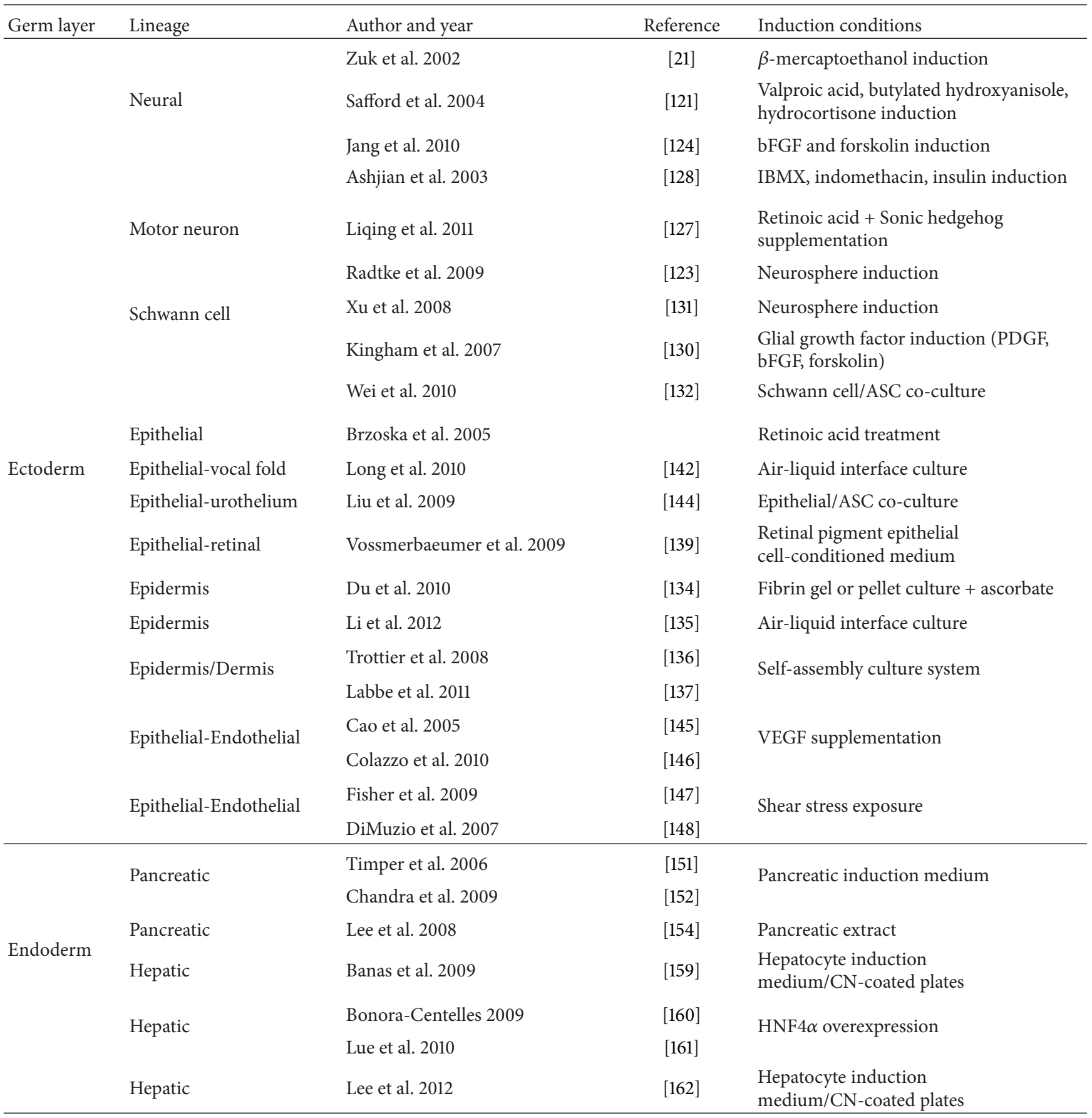

PLGA: polylactic coglycolic acid; PLA: polylactic acid, PCL: polycaprolactone; PGA: polyglycolic acid, CN: collagen, HNF4 $\alpha$ : hepatocyte nuclear factor 4 alpha. 
been reported using additional TGF $\beta$ family members such as TGF $\beta 2$ [85] and TGF $\beta 3$ [86]. Like bone, recent in vitro work has also suggested role for miRNA, implicating miR194 in the control of chondrogenesis through its ability to inhibit Sox5 expression and chondrogenesis [87]. Increased expression of collagen type II, aggrecan, and sulfated proteoglycans, all established markers of chondrogenesis, has also been observed in ASCs cultured on a variety of $3 \mathrm{D}$ scaffolds, including agarose, alginate and gelatin, crosslinked hyaluronate scaffolds and elastin-like hydrogels [8891], with modifications to the scaffold capable of delivering chondrogenic growth factors, like TGF $\beta 1$ or insulin, to the ASC and inducing their differentiation $[92,93]$. In addition to preinduced ASCs, freshly isolated SVF cells from infrapatellar fat pads increase their expression of key chondrogenic genes when seeded and induced on 3D scaffolds, demonstrating that the SVF may be used as a source of ASCs in future onestep surgical procedure to regenerate cartilage [94]. Finally, the accumulation of lipids and expression of key adipogenic genes by ASCs has also been described in vitro $[95,96]$.

2.3. Mesodermal Potentials Expanded: Skeletal, Smooth, and Cardiac Muscle. Molecular characterization of ASCs has not only described osteogenic, adipogenic and chondrogenic differentiation in vitro but has also expanded the mesodermal lineage potential of the ASC further by suggesting myogenic potentials (Table 2). In vitro studies have described the development of multinuclear cells, together with the expression of several genes consistent with myoblasts, including MyoD1, myogenin and skeletal muscle myosin together with the expression of several genes consistent with myoblasts, including MyoD1, myogenin, and skeletal muscle myosin [21]. Skeletal muscle myogenesis under defined induction conditions has since been described by others in vitro $[97,98]$ and myogenesis following coculture of ASCs with mouse myocytes has been reported by Lee and Kemp 2006 [99]. However, while these articles describe phenotypic and molecular events consistent with myogenesis, the contractile capacity of these differentiated ASCs is not reported in these articles. Furthermore, while Eom et al. 2011 report early myogenic differentiation using induction with 5-azacytidine and bFGF, terminal differentiation in the form of myotube formation can only be seen upon fusion with myoblasts [100]. This finding may be due to something as simple as substrate, as ASCs cultured on mechanically-patterned hydrogels for stiffness not only undergo myogenesis but fusion into myotube-like structures [101].

While the differentiation of ASCs into skeletal muscle would greatly benefit those suffering from disorders like muscular dystrophy, the differentiation of these stem cells to smooth muscle could conceivably have a greater impact, with the regenerated smooth muscle capable of being used for bladder and urethral reconstruction, intestinal muscle regeneration, and vascular repair. Consistent with smooth muscle myogenesis, induced ASCs are found in vitro to express established smooth muscle markers like calponin, caldesmon, and smooth muscle myosin at both the gene and protein level [102-107]. Differentiation of ASCs on elastic nanofiber scaffolds subject to mechanical stress has also been observed [108]. More importantly, many in vitro studies also report the contraction of collagen substrates, similar to smooth muscle control cells, indicating functional smooth muscle capacity. This capacity, combined with the adhesion and proliferation of ASC-derived smooth muscle cells on decellularized vascular grafts, suggests that the ASC could be used for vascular tissue engineering [105], a possibility strengthened by the finding that ASCs, seeded into polyglycolic acid (PGA) meshes and subject to pulsatile conditions in vitro in a bioreactor, acquire a dense and well-organized collagen-rich histology similar to native vessels [109].

But perhaps a more exciting development is the possible differentiation of ASCs into cardiomyogenic cells capable of contracting in a rhythmic fashion. Early work with murine MSCs describe this differentiation in 5-azacytidine treated stem cells, resulting in the production of myotubes, capable of rhythmic beating, expression of myosin and actinin, and demonstration of both SA and ventricle-like action potentials [110]. Cardiomyocyte formation using human MSCs has also been reported [111, 112]. In 2003, researchers in Singapore, identified beating cells expressing specific cardiac markers at the gene and protein level from rabbit ASCs induced using 5-azacytidine [113]. Confirmation of this work followed shortly using both human ASCs exposed to rat cardiomyocyte extracts [114] and murine ASCs induced without 5azacytidine [115]. In vitro cardiomyogenesis has also been reported upon the culturing ASCs on laminin (LN)-coated plates to drive their terminal differentiation [116], through serum deprivation and phorbol esters [117] and by direct coculture of ASCs with rat neonatal cardiomyocytes, inducing the expression of the cardiac markers GATA4, Nkx2.5, myosin heavy chain, and troponin I at the protein level [118]. Differentiation to cardiomyogenic cells expressing adrenergic receptors $(\alpha 1$ and $\beta)$, together with muscarinic receptors, L-type calcium channels, and sarcoplasmic reticulum $\mathrm{Ca} 2+$ ATPase has also induced through treatment of ASCs with the PKC activator phorbol myristate acetate [119]. Such in vitro results raise the possibility that ASCs may be useful in the treatment of myocardial infarctions.

2.4. Increased Potential of ASCs: In Vitro Ectodermal Capacity. In addition to mesodermal markers, Zuk and colleagues in 2002 reported the expression of several neural markers in induced ASCs, including nestin, NeuN, and neuron-specific enolase (NSE) [21]. Expression of these markers has been used previously in bone marrow MSCs to document their ectodermal potential [120]. However, the Woodbury et al. 2000 study used $\beta$-mercaptoethanol (BME) to induce their cells toward the neurogenic lineage. While the induction of ASCs with BME does result in cells with morphologies strikingly similar to neurons, such morphologies are also seen upon apoptosis. However, additional studies inducing ASCs with alternate agents such as valproic acid, butylated hydroxyanisole, insulin, and hydrocortisone, appear to confirm the 2002 study, not only producing cells with morphologies similar to neurons, but also resulting in cells that express markers of both the neuronal (NSE, NeuN, nestin, MAP2, tau, $\beta$-tubulin III) and glial lineages (GFAP, NG2, S100, p75 NGF receptor) [121-124]. A summary of these studies is 
outlined in Table 2. Many studies now achieve remarkable differentiation results through the creation of neurospheres [125], thus duplicating how neural progenitor populations grow and differentiate in culture [126]. Human ASC differentiation specifically into motor neurons of ventral spinal fate expressing Nkx2.2, Pax6, and Olig2 has also been suggested, offering ASCs as a potential candidate for motor neuron disease [127]. More importantly, many studies have also documented the expression of more specific neuronal markers by induced ASCs, such as components of the glutamate receptor, synapsin, and voltage-gated calcium channels [121, 124], in addition to voltage-gated sodium and potassium channels [124]. While these results are exciting, gene expression is often not sufficient to confirm potential. Therefore, several groups have shown not only differentiation at the molecular level but document electrophysiological activity with Ashjian et al. [128], identifying a delayed-rectifier $\mathrm{K}+$ current and Anghileri and colleagues measuring TTX-sensitive sodium currents in human ASC-derived neurospheres [129]. TTXsensitive sodium currents, in addition to outward potassium currents have also been measured through whole patchclamp recordings in induced ASC monolayers [124]. However, Arboleda et al. 2011 [122] do note that while membrane currents can be measured in ASCs, they are unable to detect the fast-acting $\mathrm{Na}^{+}$currents of mature neurons. As such, recent in vitro differentiation conditions may not allow for terminal differentiation of ASCs into mature, functional neurons, but the potential might be there if the appropriate culture conditions are provided.

As an alternative to forming functional neurons, other in vitro characterization studies have studied the glial capacity of ASCs $[121,123]$ in the hopes of using this stem cell population as a source of Schwann cells (SCs) capable of myelinating peripheral neurons. In support of this, human ASCs can form nestin-positive neurospheres that, upon dissociation, express characteristic SC markers like S100, GFAP, and the p75 NGF receptor [123]. Similar markers have also been seen in rat ASCs induced with mixture of glial growth factors $[130,131]$. Moreover, SC-induced ASCs also appear to possess functional capacity, demonstrating the ability to stimulate neurite outgrowth of dorsal root ganglia neurons (DRGNs) under coculture [123, 132], NG108-12 motor neurons [130], and SH-SY5Y neuroblastoma cells [131]. Interestingly, Wei et al. also report neurite formation after coculturing noninduced rat ASCs with DRGNs, suggesting that ASCs may constitutively secrete SC-derived factors [132]. However, while neurite outgrowth can be stimulated by undifferentiated ASCs, DRGN myelination is specifically seen by ASCderived SCs-a finding also reported upon coculture of rat ASC neurosphere cultures with PC12 cells [131]. Therefore, complete SC function requires differentiation of ASCs.

In 2005, the first of a series of articles suggesting that human ASCs can differentiate into epithelial cells appeared (Table 2) [133], with the cells increasing their expression of cytokeratin 18 fibers and decreasing vimentin at the protein level upon retinoic acid exposure. The expression of additional epithelial markers, like keratan sulfate, keratocan, and aldehyde dehydrogenase 3 family, member 3 has also been reported in human ASCs induced in fibrin gels or as pellet cultures [134], suggesting a potential to not only undergo epithelial differentiation but to form an epidermis. Consistent with this, rabbit ASCs induced in a 3D culture system using an air-liquid interface to induce epidermal differentiation express cytokeratins 13 and 19 consistent with the formation of this tissue [135]. Based on these studies, ASCs have been proposed as a stem cell source for skin regeneration using a novel in vitro "self-assembly" approach $[136,137]$. Specifically, human ASCs, induced with ascorbic acid, produce a dermal stromal layer that is comparable to that made by dermal fibroblast controls. Moreover, this ASC-produced stroma is capable of supporting the proliferation and differentiation of keratinocyte cultures superimposed over this stroma, inducing their production of epidermal keratins and producing a well-defined dermoepithelial junction and even the formation of epidermal stem cells [136].

In addition to markers of the epidermis, ASCs can also be induced to express markers of other epithelial tissues (Table 2), including those of renal tubules [138] and the retina [139]. Coculture of ASCs with tubular epithelial cells has been observed to increase their expression of cytokeratin 18 at the gene level, together with two more mature epithelial markers-zona occludens 1 (ZO-1) and ZO-2 [140]. Expression of cytokeratin 18 and ZO-1 has also been reported upon the treatment of ASCs with a combination of retinoic acid, activin A and BMP7 [141]. Differentiation into cytokeratin 8- and E-cadherin-positive epithelial cells of the vocal fold has also been reported in ASCs when cultured under airliquid 3D conditions upon fibrin matrices [142], with the resulting cord constructs assuming a functional phenotype capable of phonating similarly to cadaveric vocal folds [143]. Uroepithelial differentiation has recently been described in ASCs when placed into direct coculture with urothelium cells with the ASCs expressing uroplakins and cytokeratin 18 at the gene and protein level [144]. Finally, numerous in vitro studies have described the in vitro differentiation of ASCs into endothelium - a specialized epithelial tissue. Using simple in vitro induction conditions involving exposure to VEGF, ASCs express typical markers of endothelial cells, such as von Willebrand Factor (vWF) and function as endothelial cells, forming tubular structures on Matrigel substrates and taking up acetylated LDL $[107,145,146]$. Fisher and colleagues also confirm tubule formation by human ASCs, but suggest that functional LDL uptake and CD31 expression by the ASCs can only be seen upon their exposure to shear stress [147], results similar to that obtained by DiMuzio and Tulenko 2007 [148]. Furthermore, additional groups have specifically identified endothelial differentiation by CD31-ve, S100+ve ASCs [149], or CD34-ve subpopulations [150]. Therefore, these results, combined with the neural work discussed above, strongly support the theory that the ASC may also possess ectodermal lineage potential-at least under in vitro conditions.

2.5. In Vitro Endodermal Differentiation by ASCs. With these in vitro articles expanding ASC potentials to mesodermal and ectodermal, the possibility that ASCs possess pluripotent capacity like the ES cell becomes more likely. However, in order to complete the trigerm lineage potential for the 
ASC, confirmation of endodermal lineage differentiation is required. In response, numerous studies describing hepatic and pancreatic differentiation from human and rodent ASCs have been performed (Table 2). While hepatic differentiation has been more prevalent in the literature, there have been a few studies to suggest that murine and human ASCs may be induced in vitro to express pancreatic markers, such as Pdx-1, Pax4, Isl-1, Ipf-1, and Ngn3, plus their hormones insulin, somatostatin, and glucagon [151-155]. Moreover, in vivo studies can confirm the suppression of pancreatic islet damage and recovery of glycemia in STZ-induced and autoimmune models of diabetes through the administration of ASCs [156-158]. In the field of liver regeneration, Banas and colleagues were the first to show possible in vitro formation of hepatocytes by ASCs by measuring increased albumin expression by the induced ASCs at the protein level [159]. Bonora-Centelles et al. 2009 also confirm increased albumin expression, together with increased gene expression of the liver markers $\alpha 2$-macroglobuline (an acute phase protein), complement C3, selenoprotein/SEPP1 (an antioxidant), cytochrome P450 3A4, apolipoprotein E, and HNF4 $\alpha$, albeit at low levels [160]. This low level of HNF4 $\alpha$ appears to have functional consequences, apparently restricting ASC-derived hepatocytes to more immature stages, as the HNF $4 \alpha$ targets PEPCK, apolipoprotein C3 and aldolase B, are not expressed in their hepatic induced ASCs. However, when these ASCs are transduced with an $\mathrm{HNF} 4 \alpha$ adenovirus, expression of these plasma proteins is detected at both the gene and protein level, confirming that $\mathrm{HNF} 4 \alpha$-driven terminal hepatogenesis is possible in ASCs [160]. Consistent with this, Lue and coworkers find that induced ASCs exhibit low levels of five key hepatic transcription factors, including HNF4 $\alpha$ [161]. When transduced with all five factors using lentiviruses, followed by induction, a dramatic increase in albumin expression relative to untransduced controls is measured. In addition to these results, are those that also show in vitro function of ASC-derived hepatocytes, with induced cells increasing their glycogen synthesis and storage, together with increases in several enzymes involved in drug metabolism [160]. However, like many other in vitro differentiation studies, the induction conditions may only allow a certain level of differentiation as hepato-induced ASCs have been shown to exhibit no difference in urea production versus controls or in HGF secretion [162].

2.6. Pluripotency of ASCs: ES Markers. When discussing the potential of the embryonic stem (ES) cell for eventual clinical application, the most powerful argument for their use is their development into multiple cell types across all three-germ lineages. However, with the ethical issues associated with ES cell use and their potential to form teratomas in vivo, an alternate pluripotent stem cell population is greatly desired. With the in vitro differentiation of ASCs into cell types from all three germ lineages, the ASC has been suggested as one of these alternatives. When defining the characteristics of a pluripotent stem cells many groups list the following: (1) the ability to integrate into a blastocyst and form a chimera, (2) the expression of numerous cell surfaces markers such as the Stage-Specific Antigens SSEA-1/3/4, Tumor Rejection
Antigens TRA-1-60/1-81, Alkaline Phosphatase, and Ecadherin, (3) enhanced telomerase activity, and (4) the expression of several key pluripotent genes including the transcription factors Oct4 (also known as Oct3/4 or POU5F1 transcription factor), Sox2, and Nanog, in addition to the transcription factors Klf4, Rex-1 (also known as zinc finger protein/ZFP-42), and the oncogene c-myc $[163,164]$. However, in the developing embryo and its ES cells, Oct4 is thought to be the key transcription factor of "stemness" with its activity controlling the expression and activity of its downstream partners Nanog, Sox2, and Rex-1 [165-172]. Additional signaling pathways, including those of the Wntfrizzled pathway, BMP4, and integrin signaling have also been identified for their putative roles upstream of Oct4, Sox2, Nanog, and Rex-1 (for review see [173]).

In 2006, researchers at Tulane University described the expression of Oct 4 and Sox 2 in human and primate ASCs at the gene and protein level and Rex-1 at the gene level [67]. Expression of these pluripotency factors has since been confirmed in human ASCs [117, 174-176], canine ASCs [177], rodents [174], and pig [178]. While a functional role for such factors in ASCs remains unclear, Kim et al. have shown that exogenous overexpression of OCT4 results in increased telomerase activity, increased expression of numerous pluripotency markers including Nanog, Sox2, and Klf4 [179], and decreases in other genes associated with differentiation, such as nestin, Smad3, and FOXO1. Earlier studies have proposed that the increased expression of Oct4, Nanog, and Rex-1 upon the treatment of ASCs with selenium results in their reprogramming and produces more "primitive stem cells" capable of enhanced mesodermal differentiation [179]. Moreover, they show that knockdown of Rex-1 is able to significantly decrease the proliferative potential of their ASCs, a finding also reported upon Oct-4 knockdown [180]. In addition to this work, Cheng et al. have shown that the transdifferentiation capacity of human ASCs is significantly enhanced following spheroid culture-a condition found to upregulate Oct4, Sox2, and Nanog gene expression [181]. Furthermore, exogenous overexpression of Oct 4 has been shown to increase their neural differentiation both in vitro and in vivo [179]. While these studies suggest roles for these pluripotent genes in ASC proliferation and potential, the precise role for Oct4, together with Sox2 and Nanog in ASCs will require more in-depth studies. Such studies are currently being performed in human ES cells. Specifically, siRNA knockdown of Sox2 has been found to result in the loss of the ES cells' undifferentiated state, while siRNA directed to Oct4 results significant changes in the expression of numerous lineage genes such as Dkk1, brachyury, and dlx5 $[182,183]$.

\section{The True Differentiation Potential of ASCs: In Vivo Translational Models}

While these in vitro characterizations are exciting, some of them often require rather complicated induction protocols, using a combination of powerful inductive agents and growth factors. These "robust" induction conditions may not mimic the true signaling pathways that occur in vivo. As a result, 
the true test for the ASC is their differentiation and function in translational model systems. To this end, multiple translational model systems using ASCs have appeared in the literature over the last 5 years describing the beneficial use of ASCs from bone regeneration to the formation of complex tissues such as skin (outlined in Table 3). While their success does suggest that the ASC can be used in a myriad of regenerative models and protocols (as discussed below), one important question does stand out. Is tissue regeneration by ASCs a direct result of their differentiation into the desired cell type or does the ASC direct the host's ability to heal itself through paracrine signaling mechanisms? While a host of in vitro studies do support the former hypothesis, it is important to reiterate that in vitro systems are not biomimetic. Added to this, an increasing number of translational systems suggest that tissue regeneration is the result of ASC-secreted soluble factors that either induce vascularization, tissue protection or suppress the host's inflammatory pathways. In support of this, ASCs are known to secrete multiple growth factors, including VEGF, HGF, NGF and BDNF and numerous interleukins (for review see [184]). Therefore, the ASC possesses a unique "secretome" that may have powerful paracrine effects on the health, repair, and function of a tissue and has resulted in an exciting, new theory that proposes the ASC as a mediator of tissue regeneration through the secretion of specific soluble factors. However, whether direct or indirect participation may be the root cause of ASC-mediated tissue regeneration is unclear and it may be possible that the ASC uses both approaches to ensure tissue healing and health.

3.1. In Vivo Bone Regeneration. Not surprisingly, the earliest translational model systems using ASCs focused on the mesodermal potential of the ASC in bone regeneration. In bone repair, numerous translational model systems combining a variety of defect systems (i.e., cranial/parietal, craniofacialpalatal, maxillary/mandibular, long bone segmental-tibial, femoral) with ASCs from rodents, rabbits, canines, and humans have been described in the literature for well over the last decade. The first in vivo paper to describe osseous tissue formation by ASCs was reported in 2004 by Hicok et al., who seeded HA/TCP cubes with osteogenically induced human ASCs and implanted them subcutaneously in athymic mice [185]. Tissue, histologically consistent with osteoid, forms in $80 \%$ of the scaffolds. More importantly, their group also confirms the presence of human ASCs within the newly formed osteoid-a finding that is frequently overlooked in many subsequent bone regeneration studies and is required in order to assess the direct participation of the ASC in bone formation. The papers that follow appear, at first glance, to indicate that ASCs are an excellent cell source for bone regeneration. For example, Cui et al. 2007 report healing in $84 \%$ of cranial bone defects in dogs through implantation of dexamethasone-induced ASCs versus 25\% healing in acellular defects, with these acellular defects containing fibrous tissues rather than bone tissue as found in the ASC-seeded implants [186]. But a closer examination of these papers yields a more complex picture with results that are varied and dependent upon model system.
For example, bone formation has been reported by many groups using ASCs without any prior "priming" through osteoinductive agents, including (1) increased lumbar spinal fusion upon implantation of scaffolds containing syngeneic or allogeneic rat ASCs versus scaffold alone [187], (2) the induction of in vivo osteogenesis by murine ASCs using hydroxyapatite scaffolds [188], (3) near complete osseous healing of rat calvarial defects by human ASCs [189, 190], (4) parietal defect homing and healing following IV injection of humans ASCs without preinduction [191], and (5) increased healing of porcine mandibular defects using either systemic or local injections of ASCs [192]. In contrast, other groups have reported rather poor results if ASCs are implanted without this preinduction. An absence of bone formation has been found using rabbit ASCs implanted intramuscularly via polylactic coglycolic acid/beta-tricalcium phosphate (PLGA/ $\beta$ TCP) scaffolds [55]. Similarly, only 35\% of calvarial defect area is healed using undifferentiated ASCs [193]. Such results have led other bone researchers to speculate that the osteogenic potential of the ASC must be enhanced through pretreatment with osteogenic factors like dexamethasone. Indeed, the level of calvarial defect healing in the Yoon et al. 2007 study climbs significantly when the ASCs are preinduced with dexamethasone and VD3 [193]. In support of this, osteogenically primed ASCs implanted into palatal defects result in substantial bone formation versus undifferentiated ASC controls [194], osteoinduced rabbit ASCs on fibronectin polylactic acid (PLA) scaffolds to distinguish this from processed lipoaspirate (PLA) cells scaffolds outperform uninduced controls in cranial defects [195] and significant healing of cranial defects is achieved using primed rat ASCs [196].

As a natural extension to these results, ASCs pretreated with, or combined with, more powerful osteogenic growth factors like the BMP family have been studied with the thought that they may improve the osteoregenerative capacity of the ASC even further. To support this theory, Dudas et al. 2006 have shown that rabbit ASCs preinduced with BMP2 form significantly more bone versus noninduced ASC controls [197]. Similar to this, Yang et al. 2005 [198] have transduced rat ASCs with an adenoviral-BMP7 virus and concluded that these cells formed extensive new bone in vivo. ASCs transfected with a BMP6 plasmid forming more bone within a vertebral bone defect [199] have also been published. More recently, Chen et al. 2010 and Lee et al. 2010 have described the transfection of ASCs with BMP2 (in combination with VEGF or Runx2, resp.,) for the healing of ulnar defects and subcutaneous formation of bone tissue $[200,201]$. Both groups report increased bone regeneration within their defects when compared to untreated ASC controls. Therefore, the studies outlined above appear to support that ASCs modified for the delivery of BMPs can regenerate bone and that this bone formation may be enhanced through the autocrine action of the BMP on the ASC. However, in many of these studies, a key factor is missing-the amount of bone formed due to the action of the BMP itself-making it difficult to determine if the BMP-induced ASCs are directly enhancing bone formation. At a minimum, these studies do illustrate that the ASC can be used as a "cellular biopump" for 
TABLE 3: In vivo differentiation potentials of ASCs.

\begin{tabular}{|c|c|c|c|c|}
\hline Germ layer & Tissue & Author and year & Reference & Model system \\
\hline & & Hicok et al. 2004 & {$[185]$} & $\begin{array}{l}\text { HA/TCP scaffolds + hASCs, subQ } \\
\text { implantation, athymic mice }\end{array}$ \\
\hline & & Cowan et al. 2004 & {$[188]$} & $\begin{array}{l}\text { HA/PLGA scaffolds + mASCs, cranial } \\
\text { defects, mice }\end{array}$ \\
\hline & & Levi et al. 2010 & [190] & $\begin{array}{l}\text { HA/PLGA scaffolds + hASCs, cranial } \\
\text { defects, athymic mice }\end{array}$ \\
\hline & & Levi et al. 2011 & {$[189]$} & $\begin{array}{l}\text { Intravenous administration of hASCs, } \\
\text { cranial defects, athymic mice }\end{array}$ \\
\hline & & Dudas et al. 2006 & [197] & $\begin{array}{l}\text { Gelatin foam + osteo-induced rabbit ASCs, } \\
\text { BMP2 treatment, cranial defect, rabbits }\end{array}$ \\
\hline & & Yoon et al. 2007 & {$[193]$} & $\begin{array}{l}\text { PLGA scaffolds + osteo-induced hASCs, } \\
\text { cranial defect, athymic rats }\end{array}$ \\
\hline & Bone & Cui et al. 2007 & {$[186]$} & $\begin{array}{l}\text { Coral scaffolds + osteo-induced canine } \\
\text { ASCs, cranial defects, dogs }\end{array}$ \\
\hline & & Conejero et al. 2006 & {$[194]$} & $\begin{array}{l}\text { PLA scaffolds + osteo-induced rASCs, } \\
\text { palatal defects, rats }\end{array}$ \\
\hline & & Yang et al. 2005 & {$[198]$} & $\begin{array}{l}\text { CNI scaffolds + rASCs, Ad-BMP7 } \\
\text { transduction, subQ implantation, rats }\end{array}$ \\
\hline & & Sheyn et al. 2011 & [199] & $\begin{array}{l}\text { Fibrin gels + porcine ASCs, BMP6 plasmid } \\
\text { transfection, vertebral defects, athymic rats }\end{array}$ \\
\hline & & Chen et al. 2010 & {$[200]$} & $\begin{array}{l}\text { Acellular bone matrix + porcine ASCs, } \\
\text { BMP } 2 \text { and VEGF plasmid transfection, } \\
\text { ulnar defect, minipigs }\end{array}$ \\
\hline \multirow[t]{12}{*}{ Mesoderm } & & Lee et al. 2010 & {$[201]$} & $\begin{array}{l}\text { PLGA scaffolds + hASCs, BMP2/Runx2 } \\
\text { bicistronic plasmid transfection, subQ } \\
\text { implantation, athymic mice }\end{array}$ \\
\hline & & Peterson et al. 2005 & {$[203]$} & $\begin{array}{l}\mathrm{CNI} / \text { ceramic scaffolds + hASCs, Ad-BMP2 } \\
\text { transduction, femoral defects, athymic rats }\end{array}$ \\
\hline & & Chou et al. 2010 & {$[204]$} & $\begin{array}{l}\text { HA/PLGA scaffolds + hASCs, BMP2 } \\
\text { treatment, femoral defects, athymic rats }\end{array}$ \\
\hline & & Smith et al. 2011 & {$[207]$} & $\begin{array}{l}\text { CNI scaffolds + rabbit ASCs, BMP2 } \\
\text { treatment, cranial defects, rabbits }\end{array}$ \\
\hline & & Dragoo et al. 2003 & {$[208]$} & $\begin{array}{l}\text { Fibrin glue + pre-induced hASCs, } \\
\text { intramuscular implantation, athymic mice }\end{array}$ \\
\hline & \multirow{3}{*}{ Cartilage } & Jin et al. 2007 & [209] & $\begin{array}{l}\text { Alginate scaffolds + TGF } \beta 2 \text {-induced hASCs, } \\
\text { subQ implantation, athymic mice }\end{array}$ \\
\hline & & Mehlhorn et al. 2009 & {$[210]$} & $\begin{array}{l}\text { PLGA scaffolds + TGF } \beta 1 \text {-induced hASCs, } \\
\text { subQ implantation, athymic mice }\end{array}$ \\
\hline & & Dragoo et al. 2007 & {$[212]$} & $\begin{array}{l}\text { Fibrin glue + rabbit ASCs, full-thickness } \\
\text { subchondral defects, rabbits }\end{array}$ \\
\hline & \multirow{4}{*}{ Fat } & Cui et al. 2009 & {$[213]$} & $\begin{array}{l}\text { PGA scaffolds + pre-induced porcine ASCs, } \\
\text { full-thickness subchondral defects, pigs }\end{array}$ \\
\hline & & Hong et al. 2006 & {$[218]$} & $\begin{array}{l}\text { Gelatin scaffolds + pre-induced hASCs, } \\
\text { subQ implantation, athymic mice }\end{array}$ \\
\hline & & Ito et al. (In press) & {$[220]$} & $\begin{array}{l}\text { bFGF-coupled CN/gelatin scaffolds + } \\
\text { hASCs, subQ implantation }\end{array}$ \\
\hline & & Mizuno et al. 2008 & {$[217]$} & $\begin{array}{l}\text { Fibrin glue + GFP+ve mASCs, subQ } \\
\text { implantation, mice }\end{array}$ \\
\hline
\end{tabular}


TABle 3: Continued.

\begin{tabular}{|c|c|c|c|c|}
\hline Germ layer & Tissue & Author and year & Reference & Model system \\
\hline & \multirow{4}{*}{ Skeletal muscle } & Rodriguez et al. 2005 & {$[229]$} & $\begin{array}{l}\text { hASCs }+ \text { mdx murine model, hMAD } \\
\text { subpopulation }\end{array}$ \\
\hline & & Goudenege et al. 2009 & {$[230]$} & $\begin{array}{l}\text { hASCs }+ \text { mdx murine model, hMAD } \\
\text { subpopulation }\end{array}$ \\
\hline & & Liu et al. 2007 & {$[231]$} & Pre-induced hASCs + mdx murine model \\
\hline & & Vieira et al. 2008 & {$[232]$} & $\begin{array}{l}\text { hASCs + limb girdle muscular dystrophy } \\
\text { murine model, tail vein administration }\end{array}$ \\
\hline & \multirow{5}{*}{ Smooth muscle } & Jack et al. 2005 & {$[104]$} & $\begin{array}{l}\text { hASCs + bladder/urethral injection, athymic } \\
\text { mice }\end{array}$ \\
\hline & & Zhang et al. 2012 & {$[80]$} & $\begin{array}{l}\text { hASC/bladder smooth muscle co-culture }+ \\
\text { bladder injection, athymic mice }\end{array}$ \\
\hline & & Lin et al. 2010 & {$[234]$} & rASCs + SUI model, rats \\
\hline & & Zhao et al. 2011 & {$[106]$} & $\begin{array}{l}\text { rASCs + periurethral injection, PLGA/NGF } \\
\text { microspheres, SUI model, rats }\end{array}$ \\
\hline & & Zhao et al. 2012 & {$[236]$} & $\begin{array}{l}\text { Rabbit ASCs + decellularized vessel grafts, } \\
\text { ureter defect, rabbits }\end{array}$ \\
\hline & \multirow{9}{*}{ Cardiac muscle } & Zhu et al. 2010 & {$[237]$} & $\begin{array}{l}\text { Rabbit ASCs + bladder acellular matrix } \\
\text { grafts, bladder reconstruction, rabbits }\end{array}$ \\
\hline & & Mazo et al. 2008 & [247] & mASCs + MI model, athymic rats \\
\hline & & Cai et al. 2009 & {$[249]$} & hASCs + MI model, athymic rats \\
\hline & & Okura et al. 2012 & {$[241]$} & $\begin{array}{l}\text { hASC-derived cardiomyoblasts + pig MI } \\
\text { model }\end{array}$ \\
\hline & & Léobon et al. 2009 & {$[246]$} & $\begin{array}{l}\text { mASC-derived cardiomyocytes + murine } \\
\text { MI model }\end{array}$ \\
\hline & & Zhang et al. 2007 & {$[252]$} & $\begin{array}{l}\text { Rabbit ASC-derived cardiomyocytes + } \\
\text { rabbit MI model }\end{array}$ \\
\hline & & Beitnes et al. 2012 & {$[244]$} & $\begin{array}{l}\text { ASCs + intramyocardial injection, MI } \\
\text { model, athymic rats }\end{array}$ \\
\hline & & Zhang et al. 2010 & {$[248]$} & \multirow{2}{*}{$\begin{array}{l}\text { rASCs + rat MI model, injectable fibrin glue } \\
\text { scaffolds }\end{array}$} \\
\hline & & Yang et al. (In press) & {$[253]$} & \\
\hline \multirow{9}{*}{ Ectoderm } & \multirow{9}{*}{ Nerve repair } & Orbay et al. 2012 & {$[272]$} & $\begin{array}{l}\text { Neural-induced ASCs + peripheral nerve } \\
\text { gaps, rats, silicone conduits }\end{array}$ \\
\hline & & Yang et al. 2011 & {$[261]$} & $\begin{array}{l}\text { Neural induced rASCs + focal cerebral } \\
\text { ischemia, rats }\end{array}$ \\
\hline & & Park et al. 2012 & {$[267]$} & $\begin{array}{l}\text { Neural induced canine ASCs + spinal cord } \\
\text { injury, dogs, matrigel implants }\end{array}$ \\
\hline & & Lopatina et al. 2011 & {$[279]$} & $\begin{array}{l}\text { Neural induced mASCs + peroneal nerve } \\
\text { injury, mice, matrigel implants }\end{array}$ \\
\hline & & Tomita et al. 2012 & [269] & $\begin{array}{l}\text { rASC-derived Schwann cells + nerve } \\
\text { denervation model, rats }\end{array}$ \\
\hline & & Chi et al. 2010 & {$[271]$} & $\begin{array}{l}\text { rASC-derived Schwann cells + spinal cord } \\
\text { injury, rats }\end{array}$ \\
\hline & & Di Summa et al. 2010 & {$[273]$} & $\begin{array}{l}\text { rASC-derived Schwann cells + sciatic nerve } \\
\text { injury, fibrin conduits, rats }\end{array}$ \\
\hline & & Wei et al. 2009 & {$[276]$} & $\begin{array}{l}\text { rASC-conditioned media + ischemia model, } \\
\text { rats }\end{array}$ \\
\hline & & Zhang et al. 2010 & {$[282]$} & $\begin{array}{l}\text { rASCs + xenogeneic acellular nerve } \\
\text { matrices, sciatic nerve injury, rats }\end{array}$ \\
\hline
\end{tabular}


TABLE 3: Continued.

\begin{tabular}{|c|c|c|c|c|}
\hline Germ layer & Tissue & Author and year & Reference & Model system \\
\hline & \multirow{11}{*}{$\begin{array}{l}\text { Endothelial- } \\
\text { vascularization }\end{array}$} & $\begin{array}{l}\text { Planat-Benard et al. } \\
2004\end{array}$ & {$[150]$} & $\begin{array}{l}\mathrm{mASC} / \mathrm{hASC}+\text { muscle vascularization and } \\
\text { hindlimb ischemia, intramuscular injection, } \\
\text { athymic mic }\end{array}$ \\
\hline & & Moon et al. 2006 & [297] & hASCs + hindlimb ischemia model, mice \\
\hline & & Miranville et al. 2004 & {$[300]$} & $\begin{array}{l}\text { hASCs }(C D 34+/ C D 31-)+\text { hindlimb } \\
\text { ischemia model, athymic mice, IV } \\
\text { administration }\end{array}$ \\
\hline & & Kim et al. 2011 & {$[303]$} & $\begin{array}{l}\text { hASCs + ischemic limb wound, diabetic } \\
\text { model, athymic mice, local injection }\end{array}$ \\
\hline & & Liu et al. 2011 & {$[304]$} & $\begin{array}{l}\text { rASCs + pulmonary hypertension model, } \\
\text { rats }\end{array}$ \\
\hline & & Gao et al. 2011 & {$[306]$} & $\begin{array}{l}\text { hASCs + skin flaps, STZ-diabetic model, } \\
\text { athymic mice, local injection }\end{array}$ \\
\hline & & Mazo et al. (In press) & {$[311]$} & $\begin{array}{l}\text { Porcine ASCs + cardiac IR injury model, } \\
\text { mini-pigs, trans-endocardial injection }\end{array}$ \\
\hline & & Sun et al. 2011 & {$[312]$} & $\begin{array}{l}\text { rASCs + lung IR injury model, rats, IV } \\
\text { administration }\end{array}$ \\
\hline & & Furuichi et al. 2012 & {$[313]$} & $\begin{array}{l}\text { mASCs + kidney IR injury model, mice, IV } \\
\text { administration }\end{array}$ \\
\hline & & Traktuev et al. 2009 & {$[317]$} & $\begin{array}{l}\text { hASC + endothelial precursors, subQ } \\
\text { implantation, athymic mice }\end{array}$ \\
\hline & & Matsumoto et al. 2006 & {$[224]$} & $\begin{array}{l}\text { hASCs + lipoaspirate fat grafts, local } \\
\text { administration }\end{array}$ \\
\hline \multirow{9}{*}{ Endoderm } & \multirow{6}{*}{ Liver } & Kim et al. 2003 & {$[254]$} & $\begin{array}{l}\text { hASCs + partial hepatectomy, athymic mice, } \\
\text { IV administration }\end{array}$ \\
\hline & & Ruiz et al. 2010 & {$[257]$} & $\begin{array}{l}\text { hASCs }+\mathrm{CCL}_{4} \text {-induced liver injury, } \\
\text { athymic mice }\end{array}$ \\
\hline & & Banas et al. 2008 & {$[258]$} & $\begin{array}{l}\text { hASCs }+\mathrm{CCL}_{4} \text {-induced liver injury, } \\
\text { athymic mice, IV administration }\end{array}$ \\
\hline & & Wang et al. 2010 & {$[255]$} & $\begin{array}{l}\text { Pre-induced hASCs + PLGA scaffold } \\
\text { implantation, hepatectomized rats }\end{array}$ \\
\hline & & Harn et al. (In press) & {$[256]$} & $\begin{array}{l}\text { Pre-induced hASCs + TAA-induced liver } \\
\text { fibrosis model, rats, direction injection }\end{array}$ \\
\hline & & Banas et al. 2009 & {$[159]$} & $\begin{array}{l}\text { Pre-induced hASCs + CCL4-induced liver } \\
\text { injury, athymic mice }\end{array}$ \\
\hline & \multirow{3}{*}{ Pancreas } & Timper et al. 2006 & {$[151]$} & \multirow{2}{*}{ Pancreatic induction medium } \\
\hline & & Chandra et al. 2009 & {$[152]$} & \\
\hline & & Lee et al. 2008 & [154] & Pancreatic extract \\
\hline
\end{tabular}

hASCs: human ASCs; mASCs: mouse ASCs; rASCs: rat ASCs; HA: hydroxyapatite; TCP: tricalcium phosphate; PLGA: polylactic co-glycolic acid; PGA: polyglycolic acid; CNI: collagen type I; MI: myocardial infarct; SUI: stress urinary incontinence; I/R: ischemic/reperfusion; Mdx: murine muscular dystrophy model.

the delivery of osteogenic factors capable of inducing bone regeneration. Consistent with this, ASCs transduced with BMP2 and VEGF, delivered via baculovirus and transplanted into "massive" femoral defects in rabbits, were found to express these growth factors over a significant time frame with little host immune involvement [202]. In this regard, whether the ASC responds to such growth factors in an autocrine fashion and enhances bone formation may not be necessary if bony healing by the host is sufficient.

Whether BMP-treated ASCs enhance bony healing is also made more difficult when the following studies are considered. The first paper to describe the bone forming capacity of human ASCs in a bony defect model using adenovirally-delivered or recombinant BMP2 [203] reports no statistically significant difference in the amount of bone formed between the BMP2+ASC and BMP2 only groups, suggesting that the ASC does not contribute in any significant way to bone regeneration. In support of this, a recent paper in the journal Connective Tissue Research shows that femoral defect healing is comparable using either human ASC+BMP2 scaffolds or BMP2 control scaffolds [204]. Moreover, a companion paper in this journal suggests that this lack of effect may be due to a failure of the ASC to respond to the BMP2 [205]. In fact, two recent articles may suggest a deleterious 
effect in combining ASCs with BMP2 with Keibl's research group reporting reduced callus volume upon ASC+BMP2 administration [206] and Smith et al. measuring significantly reduced healing in rabbit cranial defects using BMP2+ASC compared to BMP2 alone controls [207].

3.2. In Vivo Cartilage Regeneration. Like bone, most in vivo studies using ASCs for cartilage regeneration also employ preinduction. One of the earliest studies implanted TGF $\beta 1$ induced human ASCs into intramuscular pockets in nude mice and noted the histological appearance of hyaline cartilage [208]. Similar results have since been reported using high-density, preinduced ASC monolayers or preinduction through the formation of micromass nodules, followed by seeding onto $3 \mathrm{D}$ scaffolds and subcutaneous implantation [89, 209-211]. Cartilage formation has also been reported upon the subcutaneous implantation of human preinduced ASCs transduced to express TGF $\beta 2$ and seeded onto alginate or alginate/PLGA scaffolds, suggesting that the ASC can demonstrate chondrogenic potential in vivo under the influence of the TGF $\beta$ family [85]. Using a more translational full-thickness cartilage defect, TGF $\beta 1$-induced rabbit ASCs in fibrin glue scaffolds have been found to form cartilage within the articular surface, with healing continuing down into the subchondral bone [212]. Neocartilage formation with integration with the surrounding host cartilage and bone has also been found in a larger model system using pig ASCs and full thickness articular defects [213], a model system that could provide important information on the way to the use of ASCs in the clinic. As a precursor to clinical application, successful cartilage formation in vivo has recently been reported using large-scale in vitro differentiation methods for the production of multiple spheroids suitable for implantation from human ASCS [214]. Finally, chondrogenic differentiation by ASCs in vivo cannot only be induced through their preinduction with TGF $\beta 1$, but induced in vivo by using the scaffold itself. Enhanced synthesis of cartilaginous GAGs has been reported upon the subcutaneous implantation of ASCs seeded onto fibrin/poly(lactide-co-caprolactone) constructs loaded with TGF $\beta 1$ nanoparticles [215]. In a similar vein, PLGA scaffolds, modified to slowly release plasmid DNA containing SOX-5,6 and -9 for ASC transfection, has been found to increase the expression of collagen type II protein and decrease the expression of collagen type $\mathrm{X}$ when implanted into rabbit osteochondral defects [211]. This work by Im et al. 2011 is the first to report enhanced cartilage protein synthesis by manipulating downstream chondrogenic pathways. Such work could eliminate the need for upstream growth factors in the regeneration of cartilage and could alter the chondrogenic potential of seeded ASCs by using the scaffold itself.

3.3. In Vivo Fat Regeneration. The most obvious application of the ASC would be in its development of soft tissues like adipose tissue. Yet, in comparison to articles on bone and cartilage generation, adipose tissue regeneration is underrepresented. The studies that are found can be divided into two categories: (1) de novo fat formation using ASCs and (2) the use of ASCs for the improvement/maintenance of fat grafts. In category one, ASCs, derived from GFP-transgenic mice and preinduced toward the adipogenic lineage, form tissues histologically confirmed as adipose tissue [216, 217]. Furthermore, the presence of GFP+ve cells can be confirmed in the new tissue, indicating that the ASC is, at a minimum, retained within the forming tissue and has a positive effect on adipose generation. Similar findings have also been reported using ASCs in combination with a variety of scaffolds including silk fibroin, collagen type 1, collagen/gelatin, alginate, polypropylene, and scaffolds modified for the controlled release of growth factors such as bFGF [218-222]. Human ASCs have also been used to form fat using a "self-assembly" approach in which the ASC is used to produce not only adipocytes but also its own supportive stroma [223]. Rather than trying to generate adipose tissue de novo, the studies of category two involve the improvement of transplanted fat grafts through the mixing with ASCs. In a procedure frequently termed cell assisted lipotransfer or CAL, adipose graft survival and volume can be significantly improved when combined with ASCs $[224,225]$. However, it is important to note that the increased volume of fat may not be due to direct ASC adipogenesis, but by paracrine support of the tissue through the secretion of angiogenic and/or adipogenic factors by the ASC [224].

3.4. In Vivo Muscle Regeneration. Original models for muscle regeneration focused on skeletal muscle formation using established murine models of dystrophy and muscle derived stem cells (for review see [226]). Not surprisingly, the myogenic differentiation capacity of bone marrow MSCs has been explored [10, 227]. However, functional recovery in dystrophin-deficient mice has not been observed with MSCs [228]. Unlike MSCs, recent studies using ASCs have reported some exciting results-that the implantation of human ASCs without immunosuppression into murine models of dystrophy can yield good engraftment levels and improvements in muscle function, thus allowing researchers to make more accurate conclusions about the myogenic differentiation of human ASCs in vivo. Pioneering work from Rodriguez et al. 2005 were among the first to suggest that a xenogeneic transplantation model is possible for muscle repair, with their transplantation of human ASCs into a mdx murine model resulting in substantial expression of human dystrophin in both the injected and adjacent muscle and long-term engraftment without any murine inflammatory infiltration [229]. Good engraftment with ASCs located around muscle fibers is also reported upon the injection of human ASCs virally engineered to overexpress MyoD [230]. However, both studies use a rather rare population of human ASCs, termed hMADs, produced through rapid adherence of ASCs to tissue culture polystyrene, followed by culture for up to 200 doublings. Therefore, it cannot be confirmed that these ASCs have undergone some atypical transformation making them more apt to undergo myogenesis in comparison to ASCs maintained for less time in culture.

However, there are additional studies that seem to confirm the findings of these hMAD cells. ASCs, induced to differentiate in vitro then injected into $\mathrm{mdx}$ mice, preferentially home to injured muscle and differentiate, producing transient and sequential peaks in MyoD, myogenin, myosin, 
and dystrophin, with each differentiation marker colocalizing with human b2-macroglobulin, suggesting the engraftment and direct differentiation of the human ASC within the muscle [231]. Several of these ASCs also appear to differentiate into Pax7+ve cells, a marker of muscle satellite cells, leading to the possibility of long-term engraftment and regenerative support. Like Vieira et al. 2008 human ASCs, preinduced to the myogenic lineage and injected multiple times via tail vein into a murine model for limb girdle dystrophy also show preferential homing to the injured muscle [232]. Moreover, these cells also improve the muscle's motor ability. However, these researchers suggest that their results are due to the fusion of the ASC with the host muscle, a finding that may be substantiated by that of Goudenege, who observe ASCs within the muscles fibers themselves [230] and by that of de la Garza-Rodea et al. 2012 who report the formation of "hybrid" fibers upon the implantation of labeled ASCs [227]. Whether the ASC differentiates within muscle de novo, fuses with the host muscle to drive regeneration or is involved in a combination of both, these studies do provide support for the use of human ASCs in the repair of skeletal muscle tissue. Moreover, these stem cells may be used without a substantial host immune response.

While 2005 saw the use of human ASCs in the regeneration of skeletal muscle, this year also saw their use in smooth muscle differentiation in vivo with the injection of human ASCs into athymic rats and mice, resulting in their incorporation into the smooth muscle of the bladder [104]. This incorporation and resulting smooth muscle regeneration was eventually confirmed in this group to be due to differentiation and not to fusion of the ASC to host cells [233], suggesting that ASCs may be capable of in vivo smooth muscle formation. Similar incorporation into bladder muscle and improvements in bladder function and smooth muscle content have been reported in models of stress urinary incontinence, with confirmation of ASC differentiation into smooth muscle cells being reported [234, 235]. Increased smooth muscle bundles, together with formation of stratified urothelium, have been observed upon injection of ASCs preinduced to the smooth muscle lineage [236]. In addition to this work, results from Zhao et al. in 2011 also suggest that the injection of ASCs can improve the functional capacity of smooth muscle [106]. Specifically, the injection of rat ASCs seeded onto PLGA scaffolds designed for the controlled release of NGF results in significant improvements in smooth muscle development, abdominal leak point pressure, and retrograde urethral perfusion pressure when compared to controls. More interestingly perhaps may be their finding that there are also improvements in ganglia formation within these treated urethras, suggesting that the injected ASCs, plus NGF, work together to produce innervated smooth muscle. This finding has also been observed upon the injection of rabbit ASCs seeded onto bladder acellular matrix grafts [237]. However, it is possible that these observed improvements in smooth muscle differentiation and function are due to paracrine actions of the ASC, decreasing apoptosis and maintaining vascular supply as proposed in models of diabetic bladder dysfunction [238].
In a 2007 study by Fotuhi et al., freshly isolated ASCs injected into porcine transmural infarcts were shown not to cause arrhythmia, bradycardia, or conduction block. Moreover, these ASC treated hearts required extrastimuli to induce an arrythmia, suggesting that ASCs could be used in the treatment of cardiac muscle infarcts [239]. With in vitro studies confirming the cardiomyogenic potential of these stem cells, infarct treatment could be mediated through the differentiation of ASCs into cardiomyocytes. Previous work on bone marrow MSCs supports this theory, as implantation of these stem cells has been shown to improve heart function in several model systems [111, 240]. Transplantation of human cardiomyoblast-like cells derived from ASCs results in improved cardiac function, together with the development of human cardiac $\alpha$-actin positive cell "bundles" that not only costain with a DiI label but also with the cardiac transcription factors Nkx2.5 and GATA4, supporting a role for human ASCs in cardiac repair [241]. However, there is a debate on whether the ASC contributes directly to cardiac muscle regeneration or supports this event through the production of angiogenic growth factors and cytokines.

In support of vascularization, bone marrow mononuclear cells and endothelial progenitors are known to improve cardiac function by incorporating into newly forming capillaries and releasing angiogenic factors [242, 243]. Similar events may also be induced by ASCs. In support of this, Beitnes and coworkers show significant improvement in left ventricle ejection fraction (LVEF), decreases in infarct sizes, and increases in vascularization when human ASCs are injected into infarcts in nude rats. Moreover, they specifically observe an absence of ASC engraftment, suggesting paracrine action [244]. Conditioned media from hypoxia-treated ASCs can also improve cardiac function following infarction, possibly through their specific paracrine section of VEGF-A, bFGF, and TGF $\beta 1$ [245]. Increased capillary densities/angiogenesis have also been reported using mouse ASCs injected into murine infarcts, with the ASCs taking up residence in the infarct area and EKGs showing stability of LVEF [246]; murine ASCs [247] or rat ASCs transplanted into rat infarcts resulting in significant improvement in heart function and tissue viability [248]; and human ASCs into rat infarcts, where not only increased peri-infarct capillary density is noted but increased numbers of nerve sprouts [249]. Finally, endothelial cells created from induced pluripotent ASCs (iPSCs) and injected into murine infarcts are found localized specifically around, but not directly integrated into, newly formed microvessels near the regenerating infarct region, suggesting paracrine action of these cells on the host vasculature [250]. Furthermore, these iPSC-derived ECs are specifically found to release pro-angiogenic factors in the ischemic environment of the heart. However, the possibility of direct differentiation of ASCs into cardiomyocytes cannot be discounted. Coexpression of $\beta$-galactosidase with myosin heavy chain, $\mathrm{Nkx} 2.3$, and troponin I has been observed following implantation of ASCs derived from Rosa26 mice into B6129S recipients [251]. Furthermore, while Zhang et al. 2007 do note increased capillary densities in their infarct regions, with ASCs differentiating into endothelial cells, when the infarct regions are examined histologically, the ASCs 
are thought to form islands of cardiac tissue in and around the scar [252]. Finally, real-time tracking of labeled ASCs transplanted into infarct regions via implanted fibrin scaffolds also confirms costaining of the ASC label with cardiac troponin in the infarct region [253]. Therefore, cardiac muscle regeneration by ASCs may be a combination of both direct transdifferentiation of ASCs into cardiomyocytes combined with their promotion of vascularization.

3.5. In Vivo Endoderm Regeneration. With in vitro studies suggesting hepatic potential for ASCs, translational models have attempted to confirm this capacity using parameters such as production of albumin protein together with functional assays. Initial studies in 2003 show increased engraftment of human ASCs into regenerating livers following partial hepatectomy [254]. Indicative of liver regeneration, preinduced human ASCs, loaded onto PLGA scaffolds and implanted into the peritoneum of hepatectomized rats, not only survive on-scaffold at least 14 days after implantation but aslo, like their in vitro counterparts, exhibit increased expression of liver-specific genes [255]. However, this study is unable to confirm differentiation at the functional level. In contrast, human ASCs induced toward the hepatocyte lineage and directly injected into models of liver fibrosis are found to secrete albumin and $\alpha$-fetoprotein, decrease fibrosis and inflammation and improve liver function [256]. Similarly, induced human ASCs transplanted into $\mathrm{CCl}_{4}$-injured livers in nude mice not only increase their production of albumin protein but also restore liver functions such as ammonia and purine metabolism and decrease liver injury markers, such as alanine aminotransferase and aspartate aminotransferase activity [159]. However, the authors do point out that they are unable to rule out ASC fusion with endogenous hepatocytes. Finally, whether ASCs need preinduction to increase liver regeneration is called into question as Ruiz et al. 2010 [257] have shown robust engraftment into injured livers using noninduced ASCs and Banas et al. 2008 confirm restoration of liver function using these controls [258].

3.6. In Vivo Ectoderm Regeneration-Nervous Tissue. Implantation of bone marrow MSCs into the cerebral cortex surrounding an ischemic infarct has been shown to significantly improve functional recovery, with the transplanted cells also expressing glial markers (GFAP, GalC) and markers of neurons ( $\beta 3$-tubulin, neuron-specific enolase, and several neuronfilament proteins) [259]. In addition, GFP-labelled MSCs injected into the subarachnoid space of the lumbar spine have been found on the surface and within the parenchyma of a spinal cord lesion, suggesting that adult stem cells may be used to repair nervous tissue injuries [260]. Like these MSC studies, early studies with ASCs used simple transplantation into nervous tissue injuries followed by histologic analysis and functional assessment of recovery. Improvement of deficits by transplanted ASCs has been reported in models of middle cerebral occlusion or ischemic stroke, where infarct size can be decreased upon ASC administration and sensimotor dysfunction improved [261263], spinal cord contusion injury, where GFP-labelled canine ASCs are able to improve pelvic limb function significantly versus controls, together with nerve conduction velocity [264] and peripheral nerve gaps, where ASCs seeded into acellular nerve grafts promote sciatic nerve regeneration and functional recovery in some cases at levels comparable to autografts $[265,266]$. Histologic analysis of these injury sites has suggested that ASC differentiation into neurons and/or glial cells may play a role in the functional recovery, with transplanted cells staining positively for MAP2 [262], GFAP, Tuj-1, and an oligodendrocyte marker [264]. However, differentiation into glial cells may be more likely as Ryu et al. 2009 observe less colocalization between their labeled ASCs and neurofilament marker expression [264].

As such, current in vivo studies have begun to explore the regenerative capacity of ASCs predifferentiated into Schwann cells (SCs), rather than hoping for the direct in situ differentiation of the ASCs into neurons. Current theories propose that such preinduced ASCs would support nervous tissue regeneration through their ability to support the endogenous healing response of neurons and/or to decrease gliosis (glial cell-mediated scar formation). In support of this, rats implanted with ASC-derived SCs show not only significant locomotor function recovery compared with untreated ASCs but also a reduction in gliosis [261]. Reduced fibrosis and inflammation are also observed upon implantation of predifferentiated canine ASCs into spinal cord injuries [267] and upon intrathecal administration of ASCs into a model of ischemia/reperfusion neuronal damage in rabbits [268]. In addition to reducing gliosis, ASCderived SCs also appear to mediate the host's regenerative response through their ability to direct re-myelination. Rat ASCs, differentiated to SCs and transplanted into denervated nerves, survive and maintain their differentiated state for up to 10 weeks, forming myelin sheaths and expressing key glial cell markers [269]. Additional studies utilizing ASCderived SCs in a variety of nerve injury/regeneration model systems report similar integration and myelination results $[270,271]$, together with improvements in function versus controls $[122,272]$, often giving rise to comparable nerve conduction velocities when compared to nerve grafts [272]. When examined histologically, increased axonal regeneration comparable to implantation of primary SCs can be observed using these stem cells [273]. However, more importantly, these preinduced ASCs appear to retain their SC function, with myelin fiber density and the number of myelinated fibers to unmyelinated fibers increasing upon ASC implantation and the transplanted cells being observed to wrap around NF160+ve axonalstructures [122].

While early in vitro studies suggest a neurogenic potential for ASCs, the majority of in vivo studies fail to show direct differentiation in situ of the transplanted ASCs into neurons. For example, less then $1 \%$ of transplanted ASCs are found within spinal contusive injuries, with those remaining appearing to be oligodendrocytes [274]. In addition, extremely low levels ASC differentiation into mature neurons is noted in a model of cerebral cortex injury [275]. So while the transplantation of ASCs may be successful in improving neural function, it is likely due to a supportive role in tissue healing. In 2002, Zhao et al. suggested that their observed functional recovery in ischemic brain injury models was not due to direct MSC 
differentiation into neurons but to secreted paracrine factors that acted on the host [259]. A similar hypothesis has been put forth by Wei et al. [276], who, upon infusion of ASCconditioned medium, note protection against cortical and hippocampal volume loss. In vivo protection of cerebellar granule neurons from apoptosis has also been observed using ASC-conditioned media [277]. In addition, injection of ASCs or ASC lysates into models of cavernous nerve injury is found to significantly decrease fibrosis and improve erectile function [278]. This effect is likely due to the paracrine secretion of neurotrophic factors, such as brain-derived neurotrophic factor/BDNF, nerve growth factor/NGF or glial cell-derived neurotrophic factor/GDNF, by the ASC capable of protecting host nervous tissue and/or inducing their repair. In support of this, functional deficits in a model of middle cerebral artery occlusion can also be dramatically improved using ASC transduced to overexpress BDNF [262]. Moreover, enhanced nerve fiber growth is observed in models of mice limb reinnervation using ASCs preinduced toward the neural lineage thus enhancing their production of brain-derived neurotrophic factor (BNDF) [279]. BDNF, NGF, and GDNF secretion by ASCs predifferentiated toward the SC phenotype are thought to be the basis for axonal regeneration in sciatic nerve gap models, with these factors providing neuroprotection through their antiapoptotic behavior [280]. In a similar vein, ASC-conditioned medium containing VEGF, BDNF, and NGF may protect against glutamate excitotoxicity on PC12 cells, a key factor implicated in stroke and neurodegenerative diseases, thus increasing their viability in situ [281]. Finally, an immunosuppressive role for the ASC and its paracrine factors cannot be discounted as xenogeneic acellular nerve matrices combined with autologous ASCs can be implanted without host rejection [282], making it possible that peripheral nerves repair can be accomplished using commercial nerve matrices combined with the patient's own ASCs.

3.7. In Vivo Ectoderm Regeneration-Epithelial and Epidermal Differentiation. Studies detailing nervous tissue healing are strongly supportive of the in vivo ectodermal capacity of ASCs. In vivo ectodermal capacity of ASCs is also indicated by their regeneration of epithelial tissues. ASCs, combined with scaffolds, and implanted into rat tracheal defects show the development of a pseudostratified epithelium with goblet cells $[283,284]$. In addition, a large field of research has developed suggesting the use of ASCs in epidermal and/or dermal regeneration. Increased collagen content is measured upon subcutaneous implantation of rat ASCs seeded on decellularized dermal matrix [285]. Furthermore, Trottier et al. 2008 show that skin grafts made through their "selfassembly" approach, and containing human ASCs in the dermal layer, graft well onto athymic mice and result in the production of a well-organized epidermis in vivo [136]. With their ability to differentiate into epithelial and dermal layers when seeded onto hydrogels [286, 287], the ASC may replace dermal fibroblasts in the treatment of skin wounds and disorders.

However, as with other in vivo regenerative models, studies have yet to confirm whether these ASCs directly contribute to tissue formation through differentiation or support differentiation through the production of soluble factors. A 2009 study using GFP-labelled human ASCs seeded into silk fibroin-chitosan scaffolds and implanted into fullthickness skin defects finds increased wound closure [288]. In addition, this study shows coexpression of both the GFP marker and those of epidermal epithelial cells, suggesting that wound closure is due, in part, to the differentiation of the ASC. However, wounds also show increased microvascular density and ASC differentiation into endothelial cells, possibly indicating that wound closure is due also to vascularization. In support of paracrine action, keratinocyte and/or fibroblast proliferation, together with collagen transcription/synthesis by fibroblasts, can be enhanced using ASCconditioned medium or coculture systems [289-291]. Conditioned medium made from a mixture of ASCs and dermal fibroblasts can also increase keratinocyte proliferation and migration [292, 293] and increased levels of HGF and KGF can be found in the media, suggesting a role for these factors [293]. Similar to this, stromal layers derived from human ASCs can induce the proliferation and expression of appropriate epidermal keratins when overlaid with keratinocytes, leading the authors to conclude that the ASC can be used to create a biomimetic stroma capable of stimulating epidermal development [136]. Autologous ASCs have also been found to favor epidermal healing in porcine models of cutaneous radiation injury [294] and the effects of ASC-conditioned media on aged fibroblasts have been studied as a means of developing antiaging strategies [290]. Finally, implantation of 3D skin "rafts" made from adult skin explanted onto dermal tissues containing fibroblasts and human ASCs form completely healed multilayered epidermis upon implantation into skin injuries, whereas rafts without ASCs still show significant areas of injury [295]. What paracrine factors are involved in these studies of epidermal/dermal formation remain unknown but possible paracrine factors may include HGF, VEGF, TGF $\beta 1$, TGF $\beta 3$, G-CSF, GM-CSF, IL6, and IL8 [292]. In support of this, Jung and colleagues have reported that conditioned medium from ASCs can increase CNI, CNIII, and hyaluronic acid synthesis by human dermal fibroblasts and that neutralizing antibodies to TGF $\beta 1$ can abolish this effect [296].

\section{ASC-Directed Tissue Regeneration: The Role of Vascularization}

It has long been known that vascularization is critical to tissue healing. The in vitro differentiation of ASCs to endothelial cells is not under dispute as they quickly and easily form vessel-like structures in Matrigel substrates that assume endothelial function $[145,146,297]$. Consistent with this, vessel formation has been observed in several ASC models of cardiac infarct treatment, epithelial regeneration, and neural tissue healing (discussed above). In addition, multiple studies of ischemia describe increased vascularization following ASC administration [145, 150, 297-303]. Hemodynamic abnormalities in pulmonary arterial hypertension may be reversed using ASCs-a finding thought to be attributable to their induction of angiogenesis and increased formation of small, 
pulmonary arteries [304]. Increased capillary densities and higher blood flow have been reported in several studies using ASCs for the healing of skin wounds and improvement of skin flap survival $[305,306]$. At the cosmetic level, adipose grafts, transplanted with ASCs survive at higher levels, are 35\% larger and show increased neoangiogenesis when compared to grafts transplanted without these stem cells [224, 225]. Finally, there are numerous studies detailing the use of ASCs in the treatment of ischemia/reperfusion (IR) injury. While tissue damage associated with ischemia has been well described, it is important to note that the reperfusion period is also associated with damage. Amelioration of IR damage has been described previously using MSCs, cardiac stem cells and induced pluripotent stem cells [307-310]. Transendocardial injections of ASCs in a minipig model of IR injury results in long-lasting improvements in cardiac function, along with increased angiogenesis and vasculogenesis [311]. Higher numbers of CD31+ve and vWF+ve cells have also been found in models of lung IR following ASC injection, suggesting increased vessel formation [312]. Amelioration of kidney IR injury can be achieved using ASCs [313]. However, it is important to note that the improvement in IR models may not be solely due to the ASC's effect on mediating vasculogenesis/angiogenesis. The ASCs may also mediate the damage of oxidative stresses incurred during IR. In support of this, Chen et al. 2011, using a model of kidney IR treated using direct injection of ASCs, find increased clearance of creatinine and urea from blood plasma, together with higher levels of the antioxidant markers $\mathrm{NAD}(\mathrm{P}) \mathrm{H}$ quinine oxidoreductase, heme-oxygenase 1/HO-1, glutathione peroxidase, and glutathione reductase [314]. Increased antioxidant marker levels versus controls (i.e., $\mathrm{NAD}(\mathrm{P}) \mathrm{H}$ quinine oxidoreductase and $\mathrm{HO}-1$ ) have also been reported, together with decreased hepatic oxidative stress upon multiple injections of ASCs in hepatic IR models [312].

In vivo, GFP-labelled ASCs can improve the vasculature in excisional wounds in normal and diabetic rats and are found to coexpress CD31, suggesting their endothelial differentiation [315]. Similar to this, DiI-labeled ASCs costaining for CD31 and vWF have also been found in ischemic kidneys following administration of ASCs [314]. Such results suggest that ASC administration can result in increased vessel formation through their direct differentiation. However, there are other studies that suggest the ASC participates in tissue regeneration through their production of angiogenic factors and mediation of endogenous vasculogenesis/angiogenesis $[147,316]$. For example, both in vitro and in vivo studies suggest that the ASC drives endothelial differentiation and stabilizes it through paracrine action [317]. As a candidate for mediating vessel formation, the most obvious paracrine factor is VEGF and many studies propose that it is the secretion of VEGF as the underlying reason for the improved vascularization by the ASCs [303, 306, 315, 318-321]. The ability of VEGF to stimulate neoangiogenesis is well known [322-324] and the secretion of VEGF by ASCs under normal and abnormal conditions (i.e., hypoxia) has been reported by many as the factor underlying ASC-mediated angiogenesis $[145,184,318,325,326]$. Conditioned medium, obtained from ASCs under hypoxic culture conditions in order to increase production of HGF, VEGF, and TGF $\beta$, increases endothelial cell (EC) growth and reduces their apoptosis [318]. In addition, Gao et al. 2012 report increased capillary density, together with increased expression of VEGF within the dermis of ASC-treated skin flaps [306]. Increased VEGF expression, together with increased collagen density and microvascular density, is also measured in fill-thickness rat skin grafts injected with ASCs [327]. VEGF secretion by ASCs is significantly upregulated in vitro upon metabolic induction of ischemia [328] and ischemic limbs in diabetic nude mice treated with ASCs show earlier and more abundant neovessel formation, together with increased levels of plasma VEGF [303]. Inhibition of VEGF secretion by ASCs through RNA interference (RNAi), followed by their transplantation into syngeneic models of small-for-size liver injury results in significant disturbances to graft microcirculation, serum liver functional parameters, and graft survival [329]. Finally, recent studies suggest that AKT/c-myc signaling pathways may mediate increased VEGF secretion in ASCs as the injection of constitutively active AKT/v-myc-expressing ASCs promote better wound healing compared to normal controls [330]. However, the role of other secreted factors cannot be ruled out as suppression of HGF production by ASCs through RNA interference significantly impairs ischemic tissue revascularization [321] and SDF-1 $\alpha$ from ASCs has been identified as being involved in myocardial vascularization [331]. From these studies, it can be concluded that the ASC is capable of increasing vascularization in regenerating tissues-most likely through a combined action of direct endothelial differentiation and paracrine action.

\section{ASC-Directed Tissue Regeneration: The Role of Inflammation}

Successful tissue regeneration is also reliant upon control of inflammation. Multiple in vitro and in vivo studies suggest that bone marrow MSCs possess anti-inflammatory properties that may mediate the host's immune response [332-334], thus making these cells a therapeutic approach for mediating inflammatory responses, including tissue regeneration and transplantation [332-334]. In light of the numerous similarities found between bone marrow MSCs and ASCs, it may be that ASCs are also capable of modulating host immunity through immunosuppression. Consistent with this, early in vitro work identifies numerous inflammatory mediators secreted from human ASCs, including IL6, IL8, G-CSF, GM-CSF, and MCP-1 [258]. Furthermore, ASC-mediated immunosuppression has been observed in numerous in vitro experiments utilizing the gold-standard mixed lymphocyte reaction (MLR) system [335-338]. More recently, dendritic cells cocultured with ASCs and then cultured with CD4+ T cells have been found to inhibit $\mathrm{T}$ cell activation, suggesting that the dendritic cells' ability to mediate immunity has been altered through its exposure to ASCs [339]. With regards to in vivo model systems, reduced inflammatory infiltration and airspace enlargement results upon the systemic administration of human ASCs to murine models of emphysema. Moreover, the ASCs are also observed to rescuing the suppressive effects of cigarette smoke on bone marrow hematopoietic 
progenitor function [340]. Decreased airway inflammation has been seen using murine ASCs in models of airway allergic disease [341] and decreased brain inflammation has been reported upon the administration of human ASCs into a hemorrhagic stroke model [342]. Furthermore, when ASCs are administered to an experimental model of osteoarthritis, chondroprotective effects are observed and thought to be due to anti-inflammatory actions by the ASC [343]. When the host immune response is examined closely upon the introduction of ASCs, increased T cell responses are observed using human ASCs engineered to express IL-4 [344] and increased proliferation or development of regulatory $\mathrm{T}$ cells has also been reported in hind limb allotransplantation [345] and rheumatoid arthritis [346, 347]. In contrast, decreased proliferation and/or activity of several Th subtypes capable of suppressing $\mathrm{T}$ cell responses have also been observed in numerous model systems [341, 348-351]. While the putative immunosuppressive actions of the ASC are unclear at this time, many groups have observed increased expression of anti-inflammatory factors such as IL-10 within their model system. Increased production of IL10 by splenocytes is measured in a model of experimental autoimmune hearing loss created in mice [349]. Increased IL-10 and IL4 synthesis has been measured along with decreased renal fibrosis following treatment with murine ASCs after reperfusion [352]. Increased IL-10 production has also been reported upon the administration of ASCs into models of rheumatoid arthritis [347, 348], murine dystrophy [353], experimental colitis [354], and orthotopic liver transplantation [355]. What remains unknown is whether immunosuppression by ASCs is mediated through direct cell-to-cell contact [336] or the secretion of soluble factors by the ASC that mediates the eventual reaction by the host's immune system. In support of the latter theory, inhibition of prostaglandin E2 production by indomethacin can abolish the immunosuppressive properties of ASCs [335], as can neutralizing antibodies to leukemia inhibitory factor or IL6 [356, 357]. FIn addition to these model systems, the immunosuppressive properties of ASCs is exciting in that it may allow the xenogeneic use of these stem cells in tissue regeneration without the fear of significant immune response. Moreover, the ability to use ASCs in xenogeneic models systems could allow for a more direct study of human ASCs in vivo, thus allowing researchers to more accurately predict what these cells could do clinically.

Despite not knowing the precise mechanism of ASCinduced immunosuppression, their success in mediating inflammation has led to their recent clinical application. As of 2010, there were nearly 80 diseases approved by the FDA for treatment using autologous stem cells. One of the first diseases targeted for treatment by ASCs has been in their mediation of inflammation and healing in Crohn's disease [358-364], with phase III trials currently recruiting (Clinicaltrials identifiers: NCT01011244, NCT01157650, NCT00999115, http://clinicaltrials.gov/ct2/results?term=adipose+derived+cells), in addition to one phase III trial (NCT00475410) recently completed [365]. Results from these trials are encouraging with ASC-treated patients showing significant healing of their fistulas with no safety issues. The treatment of multiple sclerosis (MS) using the SVF of adipose tissue has been described by Riordan et al. 2009, with the three enrolled patients showing improvement in numerous functional categories including balance and coordination [366]. A recent 2011 paper has discussed the application of culture expanded ASCs in the treatment of MS, in addition to other autoimmune diseases like hearing loss and rheumatoid arthritis [367]. Finally, ASCs have been proposed as a viable therapy for suppression of graft versus host disease (GVHD). GVHD is a complication frequently observed following ASCT - that is, allogeneic hematopoietic stem cell transplantation. Current therapies to extend the long-term effects of ASCT include cyclosporine A and corticosteroids to limit the host's rejection of the nonmatchd HSCs. In those patients for whom this therapy is ineffective, non HLAmatched allogeneic ASCs may offer an alternate approach through their putative immunosuppressive actions. To test this, several studies assessing the use of ASCs in GVHD have appeared in the literature, reporting relatively successful results [368-371]. More importantly, no toxic side effects are observed in these studies. In addition, the presence of donor ASCs can be verified within the epithelium of the recipient in one study, showing survival and engraftment of the ASC population [370]. Immunosuppression has also been reported clinically in a patient with pure red cell aplasia [372]. While these ASC clinical studies are not as numerous as their animal model counterparts at this time, they are beginning to appear more and more in the literature. Therefore, as more clinical studies report their findings, we should learn whether ASCs will prove useful in the clinic.

\section{The Future of ASCs}

6.1. Growth Factor Delivery. This review has presented evidence on the secretory capacity of ASCs. The ability to "fine-tune" this ability, so that the ASC becomes a "cellular biopump, secreting a desired factor could make the ASC a power therapeutic agent in a wide variety of applications. A cellular biopump is not a new concept as the engineering of numerous cell types to secrete a variety of factors has been reported in the literature for over a decade. In the field of stem cell research, bone marrow MSCs have been modified to secrete various factors, including BMP2 [373, 374], bFGF [375], IFN- $\beta$ [376], and IL12 [377]. Similar to these studies, ASCs in several osteochondral regeneration models have been engineered for the delivery of BMP4 [378], BMP2 [379, 380], BMP6 [381], and TGF $\beta 2$ [382]. Adenovirally-mediated VEGF secretion by ASCs has been used to induce vascular growth in a bone defect model [383] and adipose tissue grafts [384]. Finally, BDNF delivery by transduced ASCs has been used to improve functional deficits following middle cerebral artery occlusion when compared to control ASCs [262]. In addition, engineered ASCs may also be used in the treatment of disease. Delivery of an oncolytic myxoma virus by ASCs specifically targeting gliomas has recently been described, leading to a significant reduction in glioma size [385]. Restricted localization of ASCs to tumors and their increased apoptosis has also been reported following intravenous or subcutaneous injection of ASCs engineered to express TRAIL [386]. This approach may have far-reaching 
effects on autoimmune diseases through the ASC's ability to deliver a wide variety of immune mediators. Administration of ASCs engineered to overexpress IL4 at the time of $\mathrm{T}$ cell priming attenuates autoimmune encephalomyelitis and reduces peripheral $\mathrm{T}$ cell responses inducing an antiinflammatory response in the host [344]. With the development of inducible viral systems, ASC cellular biopumps could conceivably be controlled not only at the dose level through the number of cells delivered, but also at the temporal level, giving clinicians more precise control over their therapeutic regimen.

6.2. Induced Pluripotent Stem Cells (iPSCs). In 2009, the use of ASCs to create induced pluripotent cells (iPS cells) was reported in the Proceedings of the National Academy of Sciences, expanding the potential of the ASC even further [387]. The ectopic expression of Oct4, Sox2, Klf4, and c-myc has been shown previously to transform somatic cells, like skin fibroblasts, into iPS cells with potentials remarkably similar to ES cells [388]. The Sun et al. 2009 study confirmed that a similar approach could be used on human ASCs to create iPS cells capable of expansion with and without fibroblast feeder layers [387]. Since that time, iPS cell creation from human ASCs has been confirmed using both fresh, commercial ASC lines [389, 390] and commercial, cryopreserved ones [391]. In addition mouse ASCs [392], pig ASCs [393], and canine ASCs [191] have been used. In these studies, transformation and reprogramming is accompanied by the expression of additional pluripotent markers like the SSEAs and TRA cell surface markers in the isolated iPS colonies. Moreover, these studies confirm the in vitro formation of embryoid bodies (EBs) by their iPS cell lines and the expression of germ layer markers by cells within these EBs, such as a-smooth muscle actin, desmin and vimentin (mesoderm), GFAP and Tuj-1 (ectoderm) and a-fetoprotein, Sox17 and PDX1 (endoderm). Interestingly, while several of these studies confirm increased expression of endogenous Oct4, Nanog, Sox2, and Rex-1 following reprogramming, they point out that this expression occurs only following reprogramming, as their parental ASC lines do not express these pluripotent markers. This is in direct contrast to numerous studies that have documented their basal expression (see previous section on pluripotency). Why the discrepancy is unclear. The studies of Aoki et al. 2010, Shimada et al. 2012 and Ohnishi et al. 2012 [389-391] use commercial ASC lines, which may not truly be ASC populations. It is also possible that culture conditions and passage numbers between these studies and those reporting pluripotent gene/protein expression may differ. Finally, in addition to proposing ES-like pluripotency in vitro, these iPS studies also report teratoma formation in vivo, describing the presence of endodermal epithelia such as gut and respiratory epithelia, neuroepithelia, adipose tissue, and cartilage.

In their derivation of iPS cells from ASCs, researchers cite the enormous clinical utility for an ES-like stem cell population that can be easily derived and used without the ethical issues of an ES cell. Recent studies have begun to explore this potential. Recently, porcine ASC-derived iPS cells have been used in the creation of endothelial cells and these endothelial cells used to treat myocardial infarctions through their secretion of proangiogenic and antiapoptotic factors [393]. In addition, canine iPS cells from ASCs have also been used to treat models of myocardial infarction and hindlimb ischemia [191]. However, additional studies are lacking at this time and may represent an exciting new area of ASC research. Whether ASC-derived iPS cells will be ultimately be used clinically will depend on a couple of important factorsnamely, how easy is it to develop iPS lines and their safety. It is well known that the number of iPS cell colonies capable of expansion in vitro may be low. In one study, iPS colonies were found with frequencies ranging from 1 per 5,000 ASCs to 1 per 500,000 ASCs [389]. The first paper on ASC-derived iPS cells report reprogramming efficiencies from $0.01 \%$ on feeder free Matrigel substrates to $0.2 \%$ on mEF lines [387]. Such low colony numbers could possibly limit their future clinical use. In addition, while karyotype analysis in the majority of ASC-derived iPS studies fails to see any abnormalities, genomic instability has been reported in induced mammary stem cells, with a high frequency of genomic deletions and amplifications observed suggestive of oncogene-induced DNA replication stress [394]. Such instability could result from the transfection of the c-myc onocogene and iPS cells from ASCs have been derived without the use of c-myc [389], making possible that genomic instability could be decreased in these cells. Therefore, at this juncture, it remains unclear whether the pursuit of iPS cells from ASC lines will be beneficial.

6.3. Dedifferentiated Fat Cells (DFAT). Another interesting avenue of research being explored in the ASC field is whether dedifferentiated fat (DFAT) can be used as an additional source of stem cells [395]. Conventional wisdom used to be that once a progenitor cell had committed to its specific lineage, it remained committed. However, studies now suggest that this may not be the case as mature adipocytes can now be dedifferentiated back to a more primitive progenitor population that may be an ASC or may, at the least, share many similarities with the ASC. In support of this, DFAT cells have the same CD profile as ASCs. However, DFAT populations also appear to be more pure in comparison [396]. In addition, DFAT cells express OCT4, Sox2, c-myc, Nanog, SSEA1, and telomerase activity like ASCs, but again at higher purity levels [397]. The immunosuppressive capacity of ASCs appears to be retained in DFAT cells as they can suppress the proliferation of cocultured lymphocytes [398]. When examined for their differentiation potentials in vitro, DFAT cells exhibit differentiation similar to their ASC counterparts. For example, all-trans retinoic acid can induce the osteogenic differentiation of DFAT cells [399] and increased osteocalcin expression and calcium deposition is observed when DFAT cells are seeded onto titanium fiber meshes [400]. Moreover, osteogenically induced DFAT cells are also capable of forming osteoid when subcutaneously implanted in athymic mice [396]. The adipogenic capacity of DFAT cells has also been confirmed in vitro [401]. Beyond the mesodermal lineage, DFAT cells can express established cardiac markers when cocultured with rat cardiomyocytes or when cultured alone in methycellulose [402]. When implanted into infarcted cardiac tissues in rats, these DFAT cells convert to cardiomyocytes 
and express sarcomeric actin, in addition to increasing capillary density [402]. Finally, improved sphincter contraction and bladder regeneration is observed upon transplantation of DFAT cells [403, 404]. Therefore, it appears that the mature adipocyte may retain some of its potency despite having committed to the adipogenic lineage. This finding may now make not only the SVF fraction of adipose tissue a source of ASCs but also the adipose tissue itself, greatly increasing the potential number of multipotent (or pluripotent) cells available for eventual clinical application.

6.4. ASCs for Somatic Cell Nuclear Transfer, Immortalized ASCs, and Other Uses. While this review has concentrated on well-established and popular emerging fields in ASC research, there are smaller areas of research being done that may not receive as much attention or accolades. For example, numerous articles on the use of ASCs for the creation of iPS cells are quite popular in today's research. However, there are studies that describe the use of ASCs in reprogramming using Somatic Cell Nuclear Transfer or SCNT. Porcine ASCs selected for their long life span have been used as nuclear donors for SCNT embryos [405]. Fusion rates of up to $80 \%$ have been reported with pregnancy rates approaching $50 \%$. Cloned pigs have also been created via SCNT using preadipocytes obtained from DFAT cells [406]. Researchers at Pusan University in South Korea have produced immortalized ASC lines by stably transducing them with the catalytic subunit of the human telomerase gene (hTERT). The resulting cell lines show normal karyotypes, enhanced longevity in culture and increased differentiation potential in comparison to nontransduced controls [407]. Furthermore, no differences in engraftment levels and survival in vivo are observed using these immortalized ASCs. Similar results have been reported by Wolbank et al. 2009 [408], who also note that immortalization does not alter the immunosuppressive capacity of their ASCs. ASCs have been cultured with sutures to create "biosutures" capable of repressing inflammation in tracheal resections [409]. Finally, while decellularized dermal matrices have become quite popular in ASC-driven regeneration, the field is being expanded through studies seeding ASCs into other decellularized tissues, such as lung matrices [410] and tendons [411].

Since its first appearance in the literature in 2001, the ASC has made quite an impact on the fields of adult stem cells and regenerative medicine. It is remarkable to see how many researchers around the world have adopted the ASC as their stem cell of choice and how they continue to "push the envelope" of ASC research in new and exciting directions. As the years go on, it will be exciting to see just how many applications the ASC will have and, ultimately, how it will benefit the patient.

\section{References}

[1] P. A. Zuk, M. Zhu, H. Mizuno et al., "Multilineage cells from human adipose tissue: implications for cell-based therapies," Tissue Engineering, vol. 7, no. 2, pp. 211-228, 2001.

[2] M. Rodbell, "Metabolism of isolated fat cells," The Journal of Biological Chemistry, vol. 239, pp. 375-380, 1964.
[3] W. J. Poznanski, I. Waheed, and R. Van, "Human fat cell precursors. Morphologic and metabolic differentiation in culture," Laboratory Investigation, vol. 29, no. 5, pp. 570-576, 1973.

[4] E. M. Horwitz, K. Le Blanc, M. Dominici et al., "Clarification of the nomenclature for MSC: the international society for cellular therapy position statement," Cytotherapy, vol. 7, no. 5, pp. 393395, 2005.

[5] L. da Silva Meirelles, P. C. Chagastelles, and N. B. Nardi, "Mesenchymal stem cells reside in virtually all post-natal organs and tissues," Journal of Cell Science, vol. 119, no. 11, pp. 2204-2213, 2006.

[6] H. E. Young, M. L. Mancini, R. P. Wright et al., "Mesenchymal stem cells reside within the connective tissues of many organs," Developmental Dynamics, vol. 202, no. 2, pp. 137-144, 1995.

[7] A. J. Friedenstein, K. V. Petrakova, A. I. Kurolesova, and G. P. Frolova, "Heterotopic of bone marrow. Analysis of precursor cells for osteogenic and hematopoietic tissues," Transplantation, vol. 6, no. 2, pp. 230-247, 1968.

[8] P. Charbord, "Bone marrow mesenchymal stem cells: historical overview and concepts," Human Gene Therapy, vol. 21, no. 9, pp. 1045-1056, 2010.

[9] N. S. Hwang, C. Zhang, Y. S. Hwang, and S. Varghese, "Mesenchymal stem cell differentiation and roles in regenerative medicine," Wiley Interdisciplinary Reviews: Systems Biology and Medicine, vol. 1, no. 1, pp. 97-106, 2009.

[10] M. F. Pittenger, A. M. Mackay, S. C. Beck et al., "Multilineage potential of adult human mesenchymal stem cells," Science, vol. 284, no. 5411, pp. 143-147, 1999.

[11] M. J. Oedayrajsingh-Varma, S. M. van Ham, M. Knippenberg et al., "Adipose tissue-derived mesenchymal stem cell yield and growth characteristics are affected by the tissue-harvesting procedure," Cytotherapy, vol. 8, no. 2, pp. 166-177, 2006.

[12] Y. Zhu, T. Liu, K. Song, X. Fan, X. Ma, and Z. Cui, "Adiposederived stem cell: a better stem cell than BMSC," Cell Biochemistry and Function, vol. 26, no. 6, pp. 664-675, 2008.

[13] L. Aust, B. Devlin, S. J. Foster et al., "Yield of human adiposederived adult stem cells from liposuction aspirates," Cytotherapy, vol. 6, no. 1, pp. 7-14, 2004.

[14] X. Zhu, W. Shi, W. Tai, and F. Liu, "The comparition of biological characteristics and multilineage differentiation of bone marrow and adipose derived Mesenchymal stem cells," Cell and Tissue Research, vol. 350, no. 2, pp. 277-281, 2012.

[15] S. Gronthos, D. M. Franklin, H. A. Leddy, P. G. Robey, R. W. Storms, and J. M. Gimble, "Surface protein characterization of human adipose tissue-derived stromal cells," Journal of Cellular Physiology, vol. 189, no. 1, pp. 54-63, 2001.

[16] J. B. Mitchell, K. McIntosh, S. Zvonic et al., "Immunophenotype of human adipose-derived cells: temporal changes in stromalassociated and stem cell-associated markers," Stem Cells, vol. 24, no. 2, pp. 376-385, 2006.

[17] K. Yoshimura, T. Shigeura, D. Matsumoto et al., "Characterization of freshly isolated and cultured cells derived from the fatty and fluid portions of liposuction aspirates," Journal of Cellular Physiology, vol. 208, no. 1, pp. 64-76, 2006.

[18] M. J. Oedayrajsingh-Varma, R. G. M. Breuls, T. E. Schouten et al., "Phenotypical and functional characterization of freshly isolated adipose tissue-derived stem cells," Stem Cells and Development, vol. 16, no. 1, pp. 91-104, 2007.

[19] A. C. W. Zannettino, S. Paton, A. Arthur et al., "Multipotential human adipose-derived stromal stem cells exhibit a perivascular phenotype in vitro and in vivo," Journal of Cellular Physiology, vol. 214, no. 2, pp. 413-421, 2008. 
[20] A. J. Katz, A. Tholpady, S. S. Tholpady, H. Shang, and R. C. Ogle, "Cell surface and transcriptional characterization of human adipose-derived adherent stromal (hADAS) cells," Stem Cells, vol. 23, no. 3, pp. 412-423, 2005.

[21] P. A. Zuk, M. Zhu, P. Ashjian et al., "Human adipose tissue is a source of multipotent stem cells," Molecular Biology of the Cell, vol. 13, no. 12, pp. 4279-4295, 2002.

[22] A. C. Boquest, A. Shahdadfar, K. Frønsdal et al., "Isolation and transcription profiling of purified uncultured human stromal stem cells: alteration of gene expression after in vitro cell culture," Molecular Biology of the Cell, vol. 16, no. 3, pp. 1131-1141, 2005.

[23] W. Tang, D. Zeve, J. M. Suh et al., "White fat progenitor cells reside in the adipose vasculature," Science, vol. 322, no. 5901, pp. 583-586, 2008.

[24] M. S. Rodeheffer, K. Birsoy, and J. M. Friedman, "Identification of white adipocyte progenitor cells in vivo," Cell, vol. 135, no. 2, pp. 240-249, 2008.

[25] G. Lin, M. Garcia, H. Ning et al., "Defining stem and progenitor cells within adipose tissue," Stem Cells and Development, vol. 17, no. 6, pp. 1053-1063, 2008.

[26] L. Zimmerlin, V. S. Donnenberg, M. E. Pfeifer et al., "Stromal vascular progenitors in adult human adipose tissue," Cytometry, vol. 77, no. 1, pp. 22-30, 2010.

[27] D. O. Traktuev, S. Merfeld-Clauss, J. Li et al., "A population of multipotent CD34-positive adipose stromal cells share pericyte and mesenchymal surface markers, reside in a periendothelial location, and stabilize endothelial networks," Circulation Research, vol. 102, no. 1, pp. 77-85, 2008.

[28] X. Cai, Y. Lin, P. V. Hauschka, and B. E. Grottkau, "Adipose stem cells originate from perivascular cells," Biology of the Cell, vol. 103, no. 9, pp. 435-447, 2011.

[29] M. Crisan, S. Yap, L. Casteilla et al., "A perivascular origin for mesenchymal stem cells in multiple human organs," Cell Stem Cell, vol. 3, no. 3, pp. 301-313, 2008.

[30] J. Feng, A. Mantesso, and P. T. Sharpe, "Perivascular cells as mesenchymal stem cells," Expert Opinion on Biological Therapy, vol. 10, no. 10, pp. 1441-1451, 2010.

[31] D. L. Crandall, G. J. Hausman, and J. G. Kral, "A review of the microcirculation of adipose tissue: anatomic, metabolic, and angiogenic perspectives," Microcirculation, vol. 4, no. 2, pp. 211232, 1997.

[32] D. Zeve, W. Tang, and J. Graff, "Fighting fat with fat: the expanding field of adipose stem cells," Cell Stem Cell, vol. 5, no. 5, pp. 472-481, 2009.

[33] J. Basu, C. W. Genheimer, K. I. Guthrie et al., "Expansion of the human adipose-derived stromal vascular cell fraction yields a population of smooth muscle-like cells with markedly distinct phenotypic and functional properties relative to mesenchymal stem cells," Tissue Engineering Part C, vol. 17, no. 8, pp. 843-860, 2011.

[34] B. A. Bradley, "The role of HLA matching in transplantation," Immunology Letters, vol. 29, no. 1-2, pp. 55-59, 1991.

[35] G. Lombardi and R. Lechler, "The molecular basis of allorecognition of major histocompatibility complex molecules by $\mathrm{T}$ lymphocytes," Annali dell'Istituto Superiore di Sanita, vol. 27, no. 1, pp. 7-14, 1991.

[36] C. S. Lin, G. Lin, and T. F. Lue, "Allogeneic and xenogeneic transplantation of adipose-derived stem cells in immunocompetent recipients without immunosuppressants," Stem Cells and Development, vol. 21, no. 15, pp. 2770-2778, 2012.
[37] O. DelaRosa, B. Sanchez-Correa, S. Morgado et al., "Human adipose-derived stem cells impair natural killer cell function and exhibit low susceptibility to natural killer-mediated lysis," Stem Cells and Development, vol. 21, no. 8, pp. 1333-1343, 2012.

[38] I. V. Arutyunyan, A. A. Rzhaninova, A. V. Volkov, and D. V. Goldstein, "Effect of dexamethasone on differentiation of multipotent stromal cells from human adipose tissue," Bulletin of Experimental Biology and Medicine, vol. 147, no. 4, pp. 503-508, 2009.

[39] L. de Girolamo, M. F. Sartori, W. Albisetti, and A. T. Brini, “Osteogenic differentiation of human adipose-derived stem cells: comparison of two different inductive media," Journal of Tissue Engineering and Regenerative Medicine, vol. 1, no. 2, pp. 154-157, 2007.

[40] D. T. Leong, W. M. Khor, F. T. Chew, T. C. Lim, and D. W. Hutmacher, "Characterization of osteogenically induced adipose tissue-derived precursor cells in 2-dimensional and 3dimensional environments," Cells Tissues Organs, vol. 182, no. 1, pp. 1-11, 2006.

[41] M. G. Valorani, E. Montelatici, A. Germani et al., "Pre-culturing human adipose tissue mesenchymal stem cells under hypoxia increases their adipogenic and osteogenic differentiation potentials," Cell Proliferation, vol. 45, no. 3, pp. 225-238, 2012.

[42] C. Merceron, C. Vinatier, S. Portron et al., "Differential effects of hypoxia on osteochondrogenic potential of human adiposederived stem cells," American Journal of Physiology, vol. 298, no. 2, pp. C355-C364, 2010.

[43] B. Behr, C. Tang, G. Germann, M. T. Longaker, and N. Quarto, "Locally applied vascular endothelial growth factor a increases the osteogenic healing capacity of human adipose-derived stem cells by promoting osteogenic and endothelial differentiation," Stem Cells, vol. 29, no. 2, pp. 286-296, 2011.

[44] L. Hong, A. Colpan, I. A. Peptan, J. Daw, A. George, and C. A. Evans, "17- $\beta$ estradiol enhances osteogenic and adipogenic differentiation of human adipose-derived stromal cells," Tissue Engineering, vol. 13, no. 6, pp. 1197-1203, 2007.

[45] M. Knippenberg, M. N. Helder, J. M. A. de Blieck-Hogervorst, P. I. J. M. Wuisman, and J. Klein-Nulend, "Prostaglandins differentially affect osteogenic differentiation of human adipose tissue-derived mesenchymal stem cells," Tissue Engineering, vol. 13, no. 10, pp. 2495-2503, 2007.

[46] J. S. Park, H. N. Yang, D. G. Woo, S. Y. Jeon, and K. H. Park, "The promotion of chondrogenesis, osteogenesis, and adipogenesis of human mesenchymal stem cells by multiple growth factors incorporated into nanosphere-coated microspheres," Biomaterials, vol. 32, no. 1, pp. 28-38, 2011.

[47] I. Song, B. S. Kim, C. S. Kim, and G. I. Im, "Effects of BMP-2 and vitamin D3 on the osteogenic differentiation of adipose stem cells," Biochemical and Biophysical Research Communications, vol. 408, no. 1, pp. 126-131, 2011.

[48] L. Chen, X. Lu, S. Li, Q. Sun, W. Li, and D. Song, "Sustained delivery of BMP-2 and platelet-rich plasma-released growth factors contributes to osteogenesis of human adipose-derived stem cells," Orthopedics, vol. 35, no. 9, pp. e1402-e1409, 2012.

[49] D. Prè, G. Ceccarelli, G. Gastaldi et al., "The differentiation of human adipose-derived stem cells (hASCs) into osteoblasts is promoted by low amplitude, high frequency vibration treatment," Bone, vol. 49, no. 2, pp. 295-303, 2011.

[50] M. van Griensven, S. Diederichs, S. Roeker et al., "Mechanical strain using 2D and 3D bioreactors induces osteogenesis: implications for bone tissue engineering," Advances in Biochemical Engineering/Biotechnology, vol. 112, pp. 95-123, 2009. 
[51] X. Yang, P. Gong, Y. Lin et al., "Cyclic tensile stretch modulates osteogenic differentiation of adipose-derived stem cells via the BMP-2 pathway," Archives of Medical Science, vol. 6, no. 2, pp. 152-159, 2010.

[52] H. Gu, F. Guo, X. Zhou et al., "The stimulation of osteogenic differentiation of human adipose-derived stem cells by ionic products from akermanite dissolution via activation of the ERK pathway," Biomaterials, vol. 32, no. 29, pp. 7023-7033, 2011.

[53] J. Buschmann, L. Harter, S. Gao et al., "Tissue engineered bone grafts based on biomimetic nanocomposite PLGA/amorphous calcium phosphate scaffold and human adipose-derived stem cells," Injury, vol. 43, no. 10, pp. 1689-1697, 2012.

[54] H. Hattori, M. Sato, K. Masuoka et al., "Osteogenic potential of human adipose tissue-derived stromal cells as an alternative stem cell source," Cells Tissues Organs, vol. 178, no. 1, pp. 2-12, 2004.

[55] W. Hao, Y. Y. Hu, Y. Y. Wei et al., "Collagen I gel can facilitate homogenous bone formation of adipose-derived stem cells in PLGA- $\beta$-TCP scaffold," Cells Tissues Organs, vol. 187, no. 2, pp. 89-102, 2008.

[56] J. H. Lee, J. W. Rhie, D. Y. Oh, and S. T. Ahn, "Osteogenic differentiation of human adipose tissue-derived stromal cells (hASCs) in a porous three-dimensional scaffold," Biochemical and Biophysical Research Communications, vol. 370, no. 3, pp. 456-460, 2008.

[57] G. Marino, F. Rosso, G. Cafiero et al., “ $\beta$-Tricalcium phosphate 3D scaffold promote alone osteogenic differentiation of human adipose stem cells: in vitro study," Journal of Materials Science, vol. 21, no. 1, pp. 353-363, 2010.

[58] F. H. Shen, Q. Zeng, Q. Lv et al., "Osteogenic differentiation of adipose-derived stromal cells treated with GDF-5 cultured on a novel three-dimensional sintered microsphere matrix," Spine Journal, vol. 6, no. 6, pp. 615-623, 2006.

[59] X. Li, H. Liu, X. Niu et al., "The use of carbon nanotubes to induce osteogenic differentiation of human adipose-derived MSCs in vitro and ectopic bone formation in vivo," Biomaterials, vol. 33, no. 19, pp. 4818-4827, 2012.

[60] C. Correia, W. Grayson, R. Eton et al., "Human adipose-derived cells can serve as a single-cell source for the in vitro cultivation of vascularized bone grafts," Journal of Tissue Engineering and Regenerative Medicine. In press.

[61] S. Haimi, N. Suuriniemi, A. M. Haaparanta et al., "Growth and osteogenic differentiation of adipose stem cells on PLA/bioactive glass and PLA/ $\beta$-TCP scaffolds," Tissue Engineering, vol. 15, no. 7, pp. 1473-1480, 2009.

[62] D. T. Leong, W. K. Nah, A. Gupta, D. W. Hutmacher, and M. A. Woodruff, "The osteogenic differentiation of adipose tissuederived precursor cells in a 3D scaffold/matrix environment," Current Drug Discovery Technologies, vol. 5, no. 4, pp. 319-327, 2008.

[63] J. I. Huang, S. R. Beanes, M. Zhu, H. P. Lorenz, M. H. Hedrick, and P. Benhaim, "Rat extramedullary adipose tissue as a source of osteochondrogenic progenitor cells," Plastic and Reconstructive Surgery, vol. 109, no. 3, pp. 1033-1041, 2002.

[64] J. I. Huang, P. A. Zuk, N. F. Jones et al., "Chondrogenic potential of multipotential cells from human adipose tissue," Plastic and Reconstructive Surgery, vol. 113, no. 2, pp. 585-594, 2004.

[65] S. S. Tholpady, A. J. Katz, and R. C. Ogle, "Mesenchymal stem cells from rat visceral fat exhibit multipotential differentiation in vitro," Anatomical Record, vol. 272, no. 1, pp. 398-402, 2003.
[66] R. Ogawa, H. Mizuno, A. Watanabe, M. Migita, T. Shimada, and H. Hyakusoku, "Osteogenic and chondrogenic differentiation by adipose-derived stem cells harvested from GFP transgenic mice," Biochemical and Biophysical Research Communications, vol. 313, no. 4, pp. 871-877, 2004.

[67] R. Izadpanah, C. Trygg, B. Patel et al., "Biologic properties of mesenchymal stem cells derived from bone marrow and adipose tissue," Journal of Cellular Biochemistry, vol. 99, no. 5, pp. 1285-1297, 2006.

[68] T. Fink, J. G. Rasmussen, J. Emmersen et al., "Adipose-derived stem cells from the brown bear (Ursus arctos) spontaneously undergo chondrogenic and osteogenic differentiation in vitro," Stem Cell Research, vol. 7, no. 1, pp. 89-95, 2011.

[69] Y. Shi, J. R. Niedzinski, A. Samaniego, S. Bogdansky, and B. L. Atkinson, "Adipose-derived stem cells combined with a demineralized cancellous bone substrate for bone regeneration," Tissue Engineering, vol. 18, no. 13-14, pp. 1313-1321, 2012.

[70] H. V. Desai, I. S. Voruganti, C. Jayasuriya, Q. Chen, and E. M. Darling, "Live-cell, temporal gene expression analysis of osteogenic differentiation in adipose-derived stem cells," Tissue Engineering, vol. 19, no. 1-2, pp. 40-48, 2013.

[71] A. N. Tiaden, M. Breiden, A. Mirsaidi et al., "Human serine protease HTRA1 positively regulates osteogenesis of human bone marrow-derived mesenchymal stem cells and mineralization of differentiating bone-forming cells through the modulation of extracellular matrix protein," Stem Cells, vol. 30, no. 10, pp. 22712282, 2012.

[72] X. Hu, X. Zhang, L. Dai et al., "Histone deacetylase inhibitor trichostatin a promotes the osteogenic differentiation of rat adipose-derived stem cells by altering the epigenetic modifications on Runx2 promoter in a BMP signaling-dependent manner," Stem Cells and Development. In press.

[73] H. H. Cho, K. K. Shin, Y. J. Kim et al., "NF- $\kappa$ B activation stimulates osteogenic differentiation of mesenchymal stem cells derived from human adipose tissue by increasing TAZ expression," Journal of Cellular Physiology, vol. 223, no. 1, pp. 168-177, 2010.

[74] J. S. Lee, J. M. Lee, and G. I. Im, "Electroporation-mediated transfer of Runx2 and Osterix genes to enhance osteogenesis of adipose stem cells," Biomaterials, vol. 32, no. 3, pp. 760-768, 2011.

[75] A. Santos, A. D. Bakker, J. M. A. de Blieck-Hogervorst, and J. Klein-Nulend, "WNT5A induces osteogenic differentiation of human adipose stem cells via rho-associated kinase ROCK," Cytotherapy, vol. 12, no. 7, pp. 924-932, 2010.

[76] E. Luzi, F. Marini, S. C. Sala, I. Tognarini, G. Galli, and M. L. Brandi, "Osteogenic differentiation of human adipose tissuederived stem cells is modulated by the miR-26a targeting of the SMAD1 transcription factor," Journal of Bone and Mineral Research, vol. 23, no. 2, pp. 287-295, 2008.

[77] Q. Liu, L. Cen, H. Zhou et al., "The role of the extracellular signal-related kinase signaling pathway in osteogenic differentiation of human adipose-derived stem cells and in adipogenic transition initiated by dexamethasone," Tissue Engineering, vol. 15, no. 11, pp. 3487-3497, 2009.

[78] I. Takada, A. P. Kouzmenko, and S. Kato, "Molecular switching of osteoblastogenesis versus adipogenesis: implications for targeted therapies," Expert Opinion on Therapeutic Targets, vol. 13, no. 5, pp. 593-603, 2009.

[79] S. Huang, S. Wang, C. Bian et al., "Upregulation of miR-22 promotes osteogenic differentiation and inhibits adipogenic differentiation of human adipose tissue-derived mesenchymal 
stem cells by repressing HDAC6 protein expression," Stem Cells and Development, vol. 21, no. 13, pp. 2531-2540, 2012.

[80] Z. J. Zhang, H. Zhang, Y. Kang et al., "miRNA expression profile during osteogenic differentiation of human adipose-derived stem cells," Journal of Cellular Biochemistry, vol. 113, no. 3, pp. 888-898, 2012.

[81] J. F. Zhang, W. M. Fu, M. L. He et al., "MiR-637 maintains the balance between adipocytes and osteoblasts by directly targeting osterix," Molecular Biology of the Cell, vol. 22, no. 21, pp. 3955-3961, 2011.

[82] Y. J. Kim, S. W. Bae, S. S. Yu, Y. C. Bae, and J. S. Jung, "miR196a regulates proliferation and osteogenic differentiation in mesenchymal stem cells derived from human adipose tissue," Journal of Bone and Mineral Research, vol. 24, no. 5, pp. 816825, 2009.

[83] H. J. Kim and G. I. Im, "Chondrogenic differentiation of adipose tissue-derived mesenchymal stem cells: greater doses of growth factor are necessary," Journal of Orthopaedic Research, vol. 27, no. 5, pp. 612-619, 2009.

[84] H. A. Awad, Y. D. C. Halvorsen, J. M. Gimble, and F. Guilak, "Effects of transforming growth factor $\beta 1$ and dexamethasone on the growth and chondrogenic differentiation of adiposederived stromal cells," Tissue Engineering, vol. 9, no. 6, pp. 13011312, 2003.

[85] X. B. Jin, Y. S. Sun, K. Zhang et al., "Ectopic neocartilage formation from predifferentiated human adipose derived stem cells induced by adenoviral-mediated transfer of hTGF $\beta 2$," Biomaterials, vol. 28, no. 19, pp. 2994-3003, 2007.

[86] C. H. Lu, K. J. Lin, H. Y. Chiu et al., "Improved chondrogenesis and engineered cartilage formation from TGF- $\beta 3$-expressing adipose-derived stem cells cultured in the rotating-shaft bioreactor," Tissue Engineering A, vol. 18, no. 19-20, pp. 2114-2124, 2012.

[87] J. Xu, Y. Kang, W. M. Liao, and L. Yu, "MiR-194 regulates chondrogenic differentiation of human adipose-derived stem cells by targeting Sox5," PLoS ONE, vol. 7, no. 3, Article ID e31861, 2012.

[88] H. A. Awad, M. Q. Wickham, H. A. Leddy, J. M. Gimble, and F. Guilak, "Chondrogenic differentiation of adipose-derived adult stem cells in agarose, alginate, and gelatin scaffolds," Biomaterials, vol. 25, no. 16, pp. 3211-3222, 2004.

[89] Y. Lin, E. Luo, X. Chen et al., "Molecular and cellular characterization during chondrogenic differentiation of adipose tissuederived stromal cells in vitro and cartilage formation in vivo," Journal of Cellular and Molecular Medicine, vol. 9, no. 4, pp. 929939, 2005.

[90] H. Betre, S. R. Ong, F. Guilak, A. Chilkoti, B. Fermor, and L. A. Setton, "Chondrocytic differentiation of human adiposederived adult stem cells in elastin-like polypeptide," Biomaterials, vol. 27, no. 1, pp. 91-99, 2006.

[91] I. S. Yoon, C. W. Chung, J. H. Sung et al., "Proliferation and chondrogenic differentiation of human adipose-derived mesenchymal stem cells in porous hyaluronic acid scaffold," Journal of Bioscience and Bioengineering, vol. 112, no. 4, pp. 402-408, 2011.

[92] M. Ahearne, C. T. Buckley, and D. J. Kelly, "A growth factor delivery system for chondrogenic induction of infrapatellar fat pad-derived stem cells in fibrin hydrogels," Biotechnology and Applied Biochemistry, vol. 58, no. 5, pp. 345-352, 2011.
[93] C. Erisken, D. M. Kalyon, H. Wang, C. Örnek-Ballanco, and J. $\mathrm{Xu}$, "Osteochondral tissue formation through adiposederived stromal cell differentiation on biomimetic polycaprolactone nanofibrous scaffolds with graded insulin and $\beta$ glycerophosphate concentrations," Tissue Engineering, vol. 17, no. 9-10, pp. 1239-1252, 2011.

[94] W. J. F. M. Jurgens, A. van Dijk, B. Z. Doulabi et al., "Freshly isolated stromal cells from the infrapatellar fat pad are suitable for a one-step surgical procedure to regenerate cartilage tissue," Cytotherapy, vol. 11, no. 8, pp. 1052-1064, 2009.

[95] R. Ogawa, H. Mizuno, A. Watanabe, M. Migita, H. Hyakusoku, and T. Shimada, "Adipogenic differentiation by adipose-derived stem cells harvested from GFP transgenic mice-Including relationship of sex differences," Biochemical and Biophysical Research Communications, vol. 319, no. 2, pp. 511-517, 2004.

[96] A. M. Rodriguez, C. Elabd, F. Delteil et al., "Adipocyte differentiation of multipotent cells established from human adipose tissue," Biochemical and Biophysical Research Communications, vol. 315, no. 2, pp. 255-263, 2004.

[97] B. Zheng, B. Cao, G. Li, and J. Huard, "Mouse adipose-derived stem cells undergo multilineage differentiation in vitro but primarily osteogenic and chondrogenic differentiation in vivo," Tissue Engineering, vol. 12, no. 7, pp. 1891-1901, 2006.

[98] H. Mizuno, P. A. Zuk, M. Zhu, H. P. Lorenz, P. Benhaim, and M. H. Hedrick, "Myogenic differentiation by human processed lipoaspirate cells," Plastic and Reconstructive Surgery, vol. 109, no. 1, pp. 199-209, 2002.

[99] J. H. Lee and D. M. Kemp, "Human adipose-derived stem cells display myogenic potential and perturbed function in hypoxic conditions," Biochemical and Biophysical Research Communications, vol. 341, no. 3, pp. 882-888, 2006.

[100] Y. W. Eom, J. E. Lee, M. S. Yang et al., "Effective myotube formation in human adipose tissue-derived stem cells expressing dystrophin and myosin heavy chain by cellular fusion with mouse C2C12 myoblasts," Biochemical and Biophysical Research Communications, vol. 408, no. 1, pp. 167-173, 2011.

[101] Y. S. Choi, L. G. Vincent, A. R. Lee et al., "The alignment and fusion assembly of adipose-derived stem cells on mechanically patterned matrices," Biomaterials, vol. 33, no. 29, pp. 6943-6951, 2012.

[102] L. V. Rodríguez, Z. Alfonso, R. Zhang, J. Leung, B. Wu, and L. J. Ignarro, "Clonogenic multipotent stem cells in human adipose tissue differentiate into functional smooth muscle cells," Proceedings of the National Academy of Sciences of the United States of America, vol. 103, no. 32, pp. 12167-12172, 2006.

[103] C. Wang, S. Yin, L. Cen et al., "Differentiation of adiposederived stem cells into contractile smooth muscle cells induced by transforming growth factor- $\beta 1$ and bone morphogenetic protein-4," Tissue Engineering, vol. 16, no. 4, pp. 1201-1213, 2010.

[104] G. S. Jack, F. G. Almeida, R. Zhang, Z. C. Alfonso, P. A. Zuk, and L. V. Rodríguez, "Processed lipoaspirate cells for tissue engineering of the lower urinary tract: implications for the treatment of stress urinary incontinence and bladder reconstruction," Journal of Urology, vol. 174, no. 5, pp. 2041-2045, 2005.

[105] L. J. Harris, H. Abdollahi, P. Zhang, S. McIlhenny, T. N. Tulenko, and P. J. DiMuzio, "Differentiation of adult stem cells into smooth muscle for vascular tissue engineering," Journal of Surgical Research, vol. 168, no. 2, pp. 306-314, 2011.

[106] W. Zhao, C. Zhang, C. Jin et al., "Periurethral injection of autologous adipose-derived stem cells with controlled-release nerve growth factor for the treatment of stress urinary incontinence in a rat model," European Urology, vol. 59, no. 1, pp. 155-163, 2011. 
[107] S. Heydarkhan-Hagvall, K. Schenke-Layland, J. Q. Yang et al., "Human adipose stem cells: a potential cell source for cardiovascular tissue engineering," Cells Tissues Organs, vol. 187, no. 4, pp. 263-274, 2008.

[108] I. S. Park, S. H. Kim, D. N. Heo et al., "Synergistic effect of biochemical factors and strain on the smooth muscle cell differentiation of adipose-derived stem cells on an elastic nanofibrous scaffold," Journal of Biomaterials Science, Polymer Edition. In press.

[109] C. Wang, L. Cen, S. Yin et al., "A small diameter elastic blood vessel wall prepared under pulsatile conditions from polyglycolic acid mesh and smooth muscle cells differentiated from adipose-derived stem cells," Biomaterials, vol. 31, no. 4, pp. 621630, 2010.

[110] S. Makino, K. Fukuda, S. Miyoshi et al., "Cardiomyocytes can be generated from marrow stromal cells in vitro," Journal of Clinical Investigation, vol. 103, no. 5, pp. 697-705, 1999.

[111] C. Toma, M. F. Pittenger, K. S. Cahill, B. J. Byrne, and P. D. Kessler, "Human mesenchymal stem cells differentiate to a cardiomyocyte phenotype in the adult murine heart," Circulation, vol. 105, no. 1, pp. 93-98, 2002.

[112] W. Xu, X. Zhang, H. Qian et al., "Mesenchymal stem cells from adult human bone marrow differentiate into a cardiomyocyte phenotype in vitro," Experimental Biology and Medicine, vol. 229, no. 7, pp. 623-631, 2004.

[113] S. Rangappa, C. Fen, E. H. Lee, A. Bongso, and E. S. K. Wei, "Transformation of adult mesenchymal stem cells isolated from the fatty tissue into cardiomyocytes," Annals of Thoracic Surgery, vol. 75, no. 3, pp. 775-779, 2003.

[114] K. G. Gaustad, A. C. Boquest, B. E. Anderson, A. M. Gerdes, and P. Collas, "Differentiation of human adipose tissue stem cells using extracts of rat cardiomyocytes," Biochemical and Biophysical Research Communications, vol. 314, no. 2, pp. 420427, 2004.

[115] V. Planat-Bénard, C. Menard, M. André et al., "Spontaneous cardiomyocyte differentiation from adipose tissue stroma cells," Circulation Research, vol. 94, no. 2, pp. 223-229, 2004.

[116] A. van Dijk, H. W. M. Niessen, B. Zandieh Doulabi, F. C. Visser, and F. J. van Milligen, "Differentiation of human adiposederived stem cells towards cardiomyocytes is facilitated by laminin," Cell and Tissue Research, vol. 334, no. 3, pp. 457-467, 2008.

[117] E. Park and A. N. Patel, "Changes in the expression pattern of mesenchymal and pluripotent markers in human adiposederived stem cells," Cell Biology International, vol. 34, no. 10, pp. 979-984, 2010.

[118] Y. S. Choi, G. J. Dusting, S. Stubbs et al., "Differentiation of human adipose-derived stem cells into beating cardiomyocytes," Journal of Cellular and Molecular Medicine, vol. 14, no. 4, pp. 878-889, 2010.

[119] W. Chang, S. Lim, B. W. Song et al., "Phorbol myristate acetate differentiates human adipose-derived mesenchymal stem cells into functional cardiogenic cells," Biochemical and Biophysical Research Communications, vol. 424, no. 4, pp. 740-746, 2012.

[120] D. Woodbury, E. J. Schwarz, D.J. Prockop, and I. B. Black, "Adult rat and human bone marrow stromal cells differentiate into neurons," Journal of Neuroscience Research, vol. 61, no. 4, pp. 364-370, 2000.

[121] K. M. Safford, S. D. Safford, J. M. Gimble, A. K. Shetty, and H. E. Rice, "Characterization of neuronal/glial differentiation of murine adipose-derived adult stromal cells," Experimental Neurology, vol. 187, no. 2, pp. 319-328, 2004.
[122] D. Arboleda, S. Forostyak, P. Jendelova et al., "Transplantation of predifferentiated adipose-derived stromal cells for the treatment of spinal cord injury," Cellular and Molecular Neurobiology, vol. 31, no. 7, pp. 1113-1122, 2011.

[123] C. Radtke, B. Schmitz, M. Spies, J. D. Kocsis, and P. M. Vogt, "Peripheral glial cell differentiation from neurospheres derived from adipose mesenchymal stem cells," International Journal of Developmental Neuroscience, vol. 27, no. 8, pp. 817-823, 2009.

[124] S. Jang, H. H. Cho, Y. B. Cho, J. S. Park, and H. S. Jeong, "Functional neural differentiation of human adipose tissuederived stem cells using bFGF and forskolin," BMC Cell Biology, vol. 11, article 25, 2010.

[125] J. M. Yu, B. A. Bunnell, and S. K. Kang, "Neural differentiation of human adipose tissue-derived stem cells," Methods in Molecular Biology, vol. 702, pp. 219-231, 2011.

[126] E. A. Milward, C. G. Lundberg, B. Ge, D. Lipsitz, M. Zhao, and I. D. Duncan, "Isolation and transplantation of multipotential populations of epidermal growth factor-responsive, neural progenitor cells from the canine brain," Journal of Neuroscience Research, vol. 50, no. 5, pp. 862-871, 1997.

[127] Y. Liqing, G. Jia, C. Jiqing et al., "Directed differentiation of motor neuron cell-like cells from human adipose-derived stem cells in vitro," NeuroReport, vol. 22, no. 8, pp. 370-373, 2011.

[128] P. H. Ashjian, A. S. Elbarbary, B. Edmonds et al., "In vitro differentiation of human processed lipoaspirate cells into early neural progenitors," Plastic and Reconstructive Surgery, vol. 111, no. 6, pp. 1922-1931, 2003.

[129] E. Anghileri, S. Marconi, A. Pignatelli et al., "Neuronal differentiation potential of human adipose-derived mesenchymal stem cells," Stem Cells and Development, vol. 17, no. 5, pp. 909-916, 2008.

[130] P. J. Kingham, D. F. Kalbermatten, D. Mahay, S. J. Armstrong, M. Wiberg, and G. Terenghi, "Adipose-derived stem cells differentiate into a Schwann cell phenotype and promote neurite outgrowth in vitro," Experimental Neurology, vol. 207, no. 2, pp. 267-274, 2007.

[131] Y. Xu, Z. Liu, L. Liu et al., "Neurospheres from rat adiposederived stem cells could be induced into functional Schwann cell-like cells in vitro," BMC Neuroscience, vol. 9, article 21, 2008.

[132] Y. Wei, K. Gong, Z. Zheng et al., "Schwann-like cell differentiation of rat adipose-derived stem cells by indirect co-culture with Schwann cells in vitro," Cell Proliferation, vol. 43, no. 6, pp. 606-616, 2010.

[133] M. Brzoska, H. Geiger, S. Gauer, and P. Baer, "Epithelial differentiation of human adipose tissue-derived adult stem cells," Biochemical and Biophysical Research Communications, vol. 330, no. 1, pp. 142-150, 2005.

[134] Y. Du, D. S. Roh, M. L. Funderburgh et al., "Adipose-derived stem cells differentiate to keratocytes in vitro," Molecular Vision, vol. 16, pp. 2680-2689, 2010.

[135] H. Li, Y. Xu, Q. Fu, and C. Li, "Effects of multiple agents on epithelial differentiation of rabbit adipose-derived stem cells in 3D culture," Tissue Engineering, vol. 18, no. 17-18, pp. 1760-1770, 2012.

[136] V. Trottier, G. Marceau-Fortier, L. Germain, C. Vincent, and J. Fradette, "IFATS collection: using human adipose-derived stem/stromal cells for the production of new skin substitutes," Stem Cells, vol. 26, no. 10, pp. 2713-2723, 2008.

[137] B. Labbé, G. Marceau-Fortier, and J. Fradette, "Cell sheet technology for tissue engineering: the self-assembly approach using adipose-derived stromal cells," Methods in Molecular Biology, vol. 702, pp. 429-441, 2011. 
[138] K. Li, Q. Han, X. Yan, L. Liao, and R. C. Zhao, "Not a process of simple vicariousness, the differentiation of human adiposederived mesenchymal stem cells to renal tubular epithelial cells plays an important role in acute kidney injury repairing," Stem Cells and Development, vol. 19, no. 8, pp. 1267-1275, 2010.

[139] U. Vossmerbaeumer, S. Ohnesorge, S. Kuehl et al., "Retinal pigment epithelial phenotype induced in human adipose tissuederived mesenchymal stromal cells," Cytotherapy, vol. 11, no. 2, pp. 177-188, 2009.

[140] P. C. Baer, C. Doring, M. L. Hansmann, R. Schubert, and H. Geiger, "New insights into epithelial differentiation of human adipose-derived stem cells," Journal of Tissue Engineering and Regenerative Medicine. In press.

[141] N. Griesche, J. Bereiter-Hahn, H. Geiger, R. Schubert, and P. C. Baer, "During epithelial differentiation of human adiposederived stromal/stem cells, expression of zonula occludens protein-1 is induced by a combination of retinoic acid, activin-a and bone morphogenetic protein-7," Cytotherapy, vol. 14, no. 1, pp. 61-69, 2011.

[142] J. L. Long, P. Zuk, G. S. Berke, and D. K. Chhetri, "Epithelial differentiation of adipose-derived stem cells for laryngeal tissue engineering," Laryngoscope, vol. 120, no. 1, pp. 125-131, 2010.

[143] J. L. Long, J. Neubauer, Z. Zhang, P. Zuk, G. S. Berke, and D. K. Chhetri, "Functional testing of a tissue-engineered vocal fold cover replacement," Otolaryngology Head and Neck Surgery, vol. 142, no. 3, pp. 438-440, 2010.

[144] J. Liu, J. Huang, T. Lin, C. Zhang, and X. Yin, "Cell-to-cell contact induces human adipose tissue-derived stromal cells to differentiate into urothelium-like cells in vitro," Biochemical and Biophysical Research Communications, vol. 390, no. 3, pp. 931936, 2009.

[145] Y. Cao, Z. Sun, L. Liao, Y. Meng, Q. Han, and R. C. Zhao, "Human adipose tissue-derived stem cells differentiate into endothelial cells in vitro and improve postnatal neovascularization in vivo," Biochemical and Biophysical Research Communications, vol. 332, no. 2, pp. 370-379, 2005.

[146] F. Colazzo, A. H. Chester, P. M. Taylor, and M. H. Yacoub, "Induction of mesenchymal to endothelial transformation of adipose-derived stem cells," Journal of Heart Valve Disease, vol. 19, no. 6, pp. 736-744, 2010.

[147] L. J. Fischer, S. McIlhenny, T. Tulenko et al., "Endothelial differentiation of adipose-derived stem cells: effects of endothelial cell growth supplement and shear force," Journal of Surgical Research, vol. 152, no. 1, pp. 157-166, 2009.

[148] P. DiMuzio and T. Tulenko, "Tissue engineering applications to vascular bypass graft development: the use of adiposederived stem cells," Journal of Vascular Surgery, vol. 45, no. 6, supplement, pp. 99-103, 2007.

[149] M. Wosnitza, K. Hemmrich, A. Groger, S. Gräber, and N. Pallua, "Plasticity of human adipose stem cells to perform adipogenic and endothelial differentiation," Differentiation, vol. 75, no. 1, pp. 12-23, 2007.

[150] V. Planat-Benard, J. S. Silvestre, B. Cousin et al., "Plasticity of human adipose lineage cells toward endothelial cells: physiological and therapeutic perspectives," Circulation, vol. 109, no. 5, pp. 656-663, 2004.

[151] K. Timper, D. Seboek, M. Eberhardt et al., "Human adipose tissue-derived mesenchymal stem cells differentiate into insulin, somatostatin, and glucagon expressing cells," Biochemical and Biophysical Research Communications, vol. 341, no. 4, pp. 1135-1140, 2006.

[152] V. Chandra, G. Swetha, S. Phadnis, P. D. Nair, and R. R. Bhonde, "Generation of pancreatic hormone-expressing islet-like cell aggregates from murine adipose tissue-derived stem cells," Stem Cells, vol. 27, no. 8, pp. 1941-1953, 2009.

[153] M. L. Mohamad Buang, H. K. Seng, L. H. Chung, A. B. Saim, and R. B. Idrus, "In vitro generation of functional insulin-producing cells from lipoaspirated human adipose tissue-derived stem cells," Archives of Medical Research, vol. 43, no. 1, pp. 8388, 2012.

[154] J. Lee, D. J. Han, and S. C. Kim, "In vitro differentiation of human adipose tissue-derived stem cells into cells with pancreatic phenotype by regenerating pancreas extract," Biochemical and Biophysical Research Communications, vol. 375, no. 4, pp. 547$551,2008$.

[155] H. Okura, H. Komoda, Y. Fumimoto et al., “Transdifferentiation of human adipose tissue-derived stromal cells into insulin-producing clusters," Journal of Artificial Organs, vol. 12, no. 2, pp. 123-130, 2009.

[156] Y. Y. Li, H. H. Liu, H. L. Chen, and Y. P. Li, "Adipose-derived mesenchymal stem cells ameliorate STZ-induced pancreas damage in type 1 diabetes," Biomedical Materials and Engineering, vol. 22, no. 1, pp. 97-103, 2012.

[157] V. Chandra, G. Swetha, S. Muthyala et al., "Islet-like cell aggregates generated from human adipose tissue derived stem cells ameliorate experimental diabetes in mice," PLOS ONE, vol. 6, no. 6, Article ID e20615, 2011.

[158] E. J. Bassi, P. M. Moraes-Vieira, C. S. Moreira Sa et al., "Immune regulatory properties of allogeneic adipose-derived mesenchymal stem cells in the treatment of experimental autoimmune diabetes," Diabetes, vol. 61, no. 10, pp. 2534-2545, 2012.

[159] A. Banas, T. Teratani, Y. Yamamoto et al., "Rapid hepatic fate specification of adipose-derived stem cells and their therapeutic potential for liver failure," Journal of Gastroenterology and Hepatology, vol. 24, no. 1, pp. 70-77, 2009.

[160] A. Bonora-Centelles, R. Jover, V. Mirabet et al., "Sequential hepatogenic transdifferentiation of adipose tissue-derived stem cells: relevance of different extracellular signaling molecules, transcription factors involved, and expression of new key marker genes," Cell Transplantation, vol. 18, no. 12, pp. 1319-1340, 2009.

[161] J. Lue, G. Lin, H. Ning, A. Xiong, C. S. Lin, and J. S. Glenn, "Transdifferentiation of adipose-derived stem cells into hepatocytes: a new approach," Liver International, vol. 30, no. 6, pp. 913-922, 2010.

[162] H. J. Lee, J. Jung, K. J. Cho, C. K. Lee, S. G. Hwang, and G. J. Kim, "Comparison of in vitro hepatogenic differentiation potential between various placenta-derived stem cells and other adult stem cells as an alternative source of functional hepatocytes," Differentiation, vol. 84, no. 3, pp. 223-231, 2012.

[163] J. S. Draper, C. Pigott, J. A. Thomson, and P. W. Andrews, "Surface antigens of human embryonic stem cells: changes upon differentiation in culture," Journal of Anatomy, vol. 200, no. 3, part 3, pp. 249-258, 2002.

[164] M. K. Carpenter, E. Rosler, and M. S. Rao, "Characterization and differentiation of human embryonic stem cells," Cloning and Stem Cells, vol. 5, no. 1, pp. 79-88, 2003.

[165] M. J. Evans and M. H. Kaufman, "Establishment in culture of pluripotential cells from mouse embryos," Nature, vol. 292, no. 5819, pp. 154-156, 1981.

[166] Y. H. Loh, Q. Wu, J. L. Chew et al., "The Oct4 and Nanog transcription network regulates pluripotency in mouse embryonic stem cells," Nature Genetics, vol. 38, no. 4, pp. 431-440, 2006.

[167] J. Nichols, B. Zevnik, K. Anastassiadis et al., "Formation of pluripotent stem cells in the mammalian embryo depends on 
the POU transcription factor Oct4," Cell, vol. 95, no. 3, pp. 379391, 1998.

[168] I. Chambers, "The molecular basis of pluripotency in mouse embryonic stem cells," Cloning and Stem Cells, vol. 6, no. 4, pp. 386-391, 2004.

[169] G. M. Morrison and J. M. Brickman, "Conserved roles for Oct4 homologues in maintaining multipotency during early vertebrate development," Development, vol.133, no. 10, pp. 20112022, 2006.

[170] T. Kuroda, M. Tada, H. Kubota et al., "Octamer and sox elements are required for transcriptional cis regulation of Nanog gene expression," Molecular and Cellular Biology, vol. 25, no. 6, pp. 2475-2485, 2005.

[171] J. L. Chew, Y. H. Loh, W. Zhang et al., "Reciprocal transcriptional regulation of Pou5f1 and Sox 2 via the Oct4/Sox 2 complex in embryonic stem cells," Molecular and Cellular Biology, vol. 25, no. 14, pp. 6031-6046, 2005.

[172] R. Catena, C. Tiveron, A. Ronchi et al., "Conserved POU binding DNA sites in the Sox 2 upstream enhancer regulate gene expression in embryonic and neural stem cells," The Journal of Biological Chemistry, vol. 279, no. 40, pp. 41846-41857, 2004.

[173] M. Boiani and H. R. Schöler, "Regulatory networks in embryoderived pluripotent stem cells," Nature Reviews Molecular Cell Biology, vol. 6, no. 11, pp. 872-884, 2005.

[174] P. A. Zuk, "The intracellular distribution of the ES cell totipotent markers OCT4 and Sox 2 In adult stem cells differs dramatically according to commercial antibody used," Journal of Cellular Biochemistry, vol. 106, no. 5, pp. 867-877, 2009.

[175] P. D. Potdar and S. B. D'souza, "Ascorbic acid induces in vitro proliferation of human subcutaneous adipose tissue derived mesenchymal stem cells with upregulation of embryonic stem cell pluripotency markers Oct4 and SOX2," Human Cell, vol. 23, no. 4, pp. 152-155, 2010.

[176] U. Riekstina, I. Cakstina, V. Parfejevs et al., "Embryonic stem cell marker expression pattern in human mesenchymal stem cells derived from bone marrow, adipose tissue, heart and dermis," Stem Cell Reviews and Reports, vol. 5, no. 4, pp. 378386, 2010.

[177] A. H. Kisiel, L. A. McDuffee, E. Masaoud, T. R. Bailey, B. P. Esparza Gonzalez, and R. Nino-Fong, "Isolation, characterization, and in vitro proliferation of canine mesenchymal stem cells derived from bone marrow, adipose tissue, muscle, and periosteum," American Journal of Veterinary Research, vol. 73, no. 8, pp. 1305-1317, 2012.

[178] L. Tang, Y. Yin, H. Zhou et al., "Proliferative capacity and pluripotent characteristics of porcine adult stem cells derived from adipose tissue and bone marrow," Cellular Reprogramming, vol. 14, no. 4, pp. 342-352, 2012.

[179] J. H. Kim, M. R. Lee, J. H. Kim, M. K. Jee, and S. K. Kang, "IFATS collection: selenium induces improvement of stem cell behaviors in human adipose-tissue stromal cells via SAPK/JNK and stemness acting signals," Stem Cells, vol. 26, no. 10, pp. 2724-2734, 2008.

[180] J. H. Kim, M. K. Jee, S. Y. Lee et al., "Regulation of adipose tissue stromal cells behaviors by endogenic Oct4 expression control," PLoS ONE, vol. 4, no. 9, Article ID e7166, 2009.

[181] N. C. Cheng, S. Wang, and T. H. Young, "The influence of spheroid formation of human adipose-derived stem cells on chitosan films on stemness and differentiation capabilities," Biomaterials, vol. 33, no. 6, pp. 1748-1758, 2012.

[182] H. Fong, K. A. Hohenstein, and P. J. Donovan, "Regulation of self-renewal and pluripotency by Sox 2 in human embryonic stem cells," Stem Cells, vol. 26, no. 8, pp. 1931-1938, 2008.
[183] Y. Babaie, R. Herwig, B. Greber et al., "Analysis of Oct4dependent transcriptional networks regulating self-renewal and pluripotency in human embryonic stem cells," Stem Cells, vol. 25, no. 2, pp. 500-510, 2007.

[184] A. J. B. O. G. Salgado, R. L. G. Reis, N. J. C. Sousa, and J. M. Gimble, "Adipose tissue derived stem cells secretome: soluble factors and their roles in regenerative medicine," Current Stem Cell Research and Therapy, vol. 5, no. 2, pp. 103-110, 2010.

[185] K. C. Hicok, T. V. Du Laney, Y. S. Zhou et al., "Human adiposederived adult stem cells produce osteoid in vivo," Tissue Engineering, vol. 10, no. 3-4, pp. 371-380, 2004.

[186] L. Cui, B. Liu, G. Liu et al., "Repair of cranial bone defects with adipose derived stem cells and coral scaffold in a canine model," Biomaterials, vol. 28, no. 36, pp. 5477-5486, 2007.

[187] M. J. Lopez, K. R. McIntosh, N. D. Spencer et al., "Acceleration of spinal fusion using syngeneic and allogeneic adult adipose derived stem cells in a rat model," Journal of Orthopaedic Research, vol. 27, no. 3, pp. 366-373, 2009.

[188] C. M. Cowan, Y. Y. Shi, O. O. Aalami et al., "Adipose-derived adult stromal cells heal critical-size mouse calvarial defects," Nature Biotechnology, vol. 22, no. 5, pp. 560-567, 2004.

[189] B. Levi, A. W. James, E. R. Nelson et al., "Studies in adiposederived stromal cells: migration and participation in repair of cranial injury after systemic injection," Plastic and Reconstructive Surgery, vol. 127, no. 3, pp. 1130-1140, 2011.

[190] B. Levi, A. W. James, E. R. Nelson et al., "Human adipose derived stromal cells heal critical size mouse calvarial defects," PLoS ONE, vol. 5, no. 6, Article ID el1177, 2010.

[191] A. S. Lee, D. Xu, J. R. Plews et al., "Preclinical derivation and imaging of autologously transplanted canine induced pluripotent stem cells," The Journal of Biological Chemistry, vol. 286, no. 37, pp. 32697-32704, 2011.

[192] S. M. Wilson, M. S. Goldwasser, S. G. Clark et al., "Adiposederived mesenchymal stem cells enhance healing of mandibular defects in the ramus of swine," Journal of Oral and Maxillofacial Surgery, vol. 70, no. 3, pp. e193-e203, 2012.

[193] E. Yoon, S. Dhar, D. E. Chun, N. A. Gharibjanian, and G. R. D. Evans, "In vivo osteogenic potential of human adiposederived stem cells/poly lactide-co-glycolic acid constructs for bone regeneration in a rat critical-sized calvarial defect model," Tissue Engineering, vol. 13, no. 3, pp. 619-627, 2007.

[194] J. A. Conejero, J. A. Lee, B. M. Parrett et al., "Repair of palatal bone defects using osteogenically differentiated fat-derived stem cells," Plastic and Reconstructive Surgery, vol. 117, no. 3, pp. 857-863, 2006.

[195] C. Di Bella, P. Farlie, and A. J. Penington, "Bone regeneration in a rabbit critical-sized skull defect using autologous adiposederived cells," Tissue Engineering, vol. 14, no. 4, pp. 483-490, 2008.

[196] Y. Lin, T. Wang, L. Wu et al., "Ectopic and in situ bone formation of adipose tissue-derived stromal cells in biphasic calcium phosphate nanocomposite," Journal of Biomedical Materials Research, vol. 81, no. 4, pp. 900-910, 2007.

[197] J. R. Dudas, K. G. Marra, G. M. Cooper et al., "The osteogenic potential of adipose-derived stem cells for the repair of rabbit calvarial defects," Annals of Plastic Surgery, vol. 56, no. 5, pp. 543-548, 2006.

[198] M. Yang, Q. J. Ma, G. T. Dang, K. T. Ma, P. Chen, and C. Y. Zhou, "In vitro and in vivo induction of bone formation based on ex vivo gene therapy using rat adipose-derived adult stem cells expressing BMP-7," Cytotherapy, vol. 7, no. 3, pp. 273-281, 2005. 
[199] D. Sheyn, I. Kallai, W. Tawackoli et al., "Gene-modified adult stem cells regenerate vertebral bone defect in a rat model," Molecular Pharmaceutics, vol. 8, no. 5, pp. 1592-1601, 2011.

[200] Q. Chen, Z. Yang, S. Sun et al., "Adipose-derived stem cells modified genetically in vivo promote reconstruction of bone defects," Cytotherapy, vol. 12, no. 6, pp. 831-840, 2010.

[201] S. J. Lee, S. W. Kang, H. J. Do et al., "Enhancement of bone regeneration by gene delivery of BMP2/Runx2 bicistronic vector into adipose-derived stromal cells," Biomaterials, vol. 31, no. 21, pp. 5652-5659, 2010.

[202] C. Y. Lin, K. J. Lin, K. C. Li et al., "Immune responses during healing of massive segmental femoral bone defects mediated by hybrid baculovirus-engineered ASCs," Biomaterials, vol. 33, no. 30, pp. 7422-7434, 2012.

[203] B. Peterson, J. Zhang, R. Iglesias et al., "Healing of critically sized femoral defects, using genetically modified mesenchymal stem cells from human adipose tissue," Tissue Engineering, vol. 11, no. 1-2, pp. 120-129, 2005.

[204] Y. F. Chou, P. A. Zuk, T. L. Chang, P. Benhaim, and B. M. Wu, "Adipose-derived stem cells and BMP2: part 1. BMP2-treated adipose-derived stem cells do not improve repair of segmental femoral defects," Connective Tissue Research, vol. 52, no. 2, pp. 109-118, 2011.

[205] P. Zuk, Y. F. Chou, F. Mussano, P. Benhaim, and B. M. Wu, "Adipose-derived stem cells and BMP2: part 2. BMP2 may not influence the osteogenic fate of human adipose-derived stem cells," Connective Tissue Research, vol. 52, no. 2, pp. 119-132, 2011.

[206] C. Keibl, A. Fügl, G. Zanoni et al., "Human adipose derived stem cells reduce callus volume upon BMP-2 administration in bone regeneration," Injury, vol. 42, no. 8, pp. 814-820, 2011.

[207] D. M. Smith, G. M. Cooper, A. M. Afifi et al., "Regenerative surgery in cranioplasty revisited: the role of adipose-derived stem cells and BMP-2," Plastic and Reconstructive Surgery, vol. 128, no. 5, pp. 1053-1060, 2011.

[208] J. L. Dragoo, B. Samimi, M. Zhu et al., "Tissue-engineered cartilage and bone using stem cells from human infrapatellar fat pads," Journal of Bone and Joint Surgery, vol. 85, no. 5, pp. 740-747, 2003.

[209] X. B. Jin, Y. S. Sun, K. Zhang, J. Wang, X. D. Ju, and S. Q. Lou, "Neocartilage formation from predifferentiated human adipose derived stem cells in vivo," Acta Pharmacologica Sinica, vol. 28, no. 5, pp. 663-671, 2007.

[210] A. T. Mehlhorn, J. Zwingmann, G. Finkenzeller et al., "Chondrogenesis of adipose-derived adult stem cells in a poly-lactideco-glycolide scaffold," Tissue Engineering A, vol. 15, no. 5, pp. 1159-1167, 2009.

[211] G. I. Im, H. J. Kim, and J. H. Lee, "Chondrogenesis of adipose stem cells in a porous PLGA scaffold impregnated with plasmid DNA containing SOX trio (SOX-5,-6 and -9) genes," Biomaterials, vol. 32, no. 19, pp. 4385-4392, 2011.

[212] J. L. Dragoo, G. Carlson, F. McCormick et al., "Healing fullthickness cartilage defects using adipose-derived stem cells," Tissue Engineering, vol. 13, no. 7, pp. 1615-1621, 2007.

[213] L. Cui, Y. Wu, L. Cen et al., "Repair of articular cartilage defect in non-weight bearing areas using adipose derived stem cells loaded polyglycolic acid mesh," Biomaterials, vol. 30, no. 14, pp. 2683-2693, 2009.

[214] H. H. Yoon, S. H. Bhang, J. Y. Shin, J. Shin, and B. S. Kim, "Enhanced cartilage formation via three-dimensional cell engineering of human adipose-derived stem cells," Tissue Engineering, vol. 18, no. 19-20, pp. 1949-1956, 2012.
[215] Y. Jung, Y. I. Chung, S. H. Kim et al., "In situ chondrogenic differentiation of human adipose tissue-derived stem cells in a TGF- $\beta 1$ loaded fibrin-poly(lactide-caprolactone) nanoparticulate complex," Biomaterials, vol. 30, no. 27, pp. 4657-4664, 2009.

[216] F. Lu, J. H. Gao, R. Ogawa, H. Mizuro, and H. Hykusoku, "Adipose tissues differentiated by adipose-derived stem cells harvested from transgenic mice," Chinese Journal of Traumatology, vol. 9, no. 6, pp. 359-364, 2006.

[217] H. Mizuno, Y. Itoi, S. Kawahara, R. Ogawa, S. Akaishi, and H. Hyakusoku, "In vivo adipose tissue regeneration by adiposederived stromal cells isolated from GFP transgenic mice," Cells Tissues Organs, vol. 187, no. 3, pp. 177-185, 2008.

[218] L. Hong, I. A. Peptan, A. Colpan, and J. L. Daw, "Adipose tissue engineering by human adipose-derived stromal cells," Cells Tissues Organs, vol. 183, no. 3, pp. 133-140, 2006.

[219] J. R. Mauney, T. Nguyen, K. Gillen, C. Kirker-Head, J. M. Gimble, and D. L. Kaplan, "Engineering adipose-like tissue in vitro and in vivo utilizing human bone marrow and adiposederived mesenchymal stem cells with silk fibroin 3D scaffolds," Biomaterials, vol. 28, no. 35, pp. 5280-5290, 2007.

[220] R. Ito, N. Morimoto, P. H. Liem et al., "Adipogenesis using human adipose tissue-derived stromal cells combined with a collagen/gelatin sponge sustaining release of basic fibroblast growth factor," Journal of Tissue Engineering and Regenerative Medicine. In press.

[221] W. Tsuji, T. Inamoto, H. Yamashiro et al., "Adipogenesis induced by human adipose tissue-derived stem cells," Tissue Engineering A, vol. 15, no. 1, pp. 83-93, 2009.

[222] M. Handel, T. R. Hammer, and D. Hoefer, "Adipogenic differentiation of scaffold-bound human adipose tissue-derived stem cells (hASC) for soft tissue engineering," Biomedical Materials, vol. 7, no. 5, Article ID 054107, 2012.

[223] M. Vermette, V. Trottier, V. Ménard, L. Saint-Pierre, A. Roy, and J. Fradette, "Production of a new tissue-engineered adipose substitute from human adipose-derived stromal cells," Biomaterials, vol. 28, no. 18, pp. 2850-2860, 2007.

[224] D. Matsumoto, K. Sato, K. Gonda et al., "Cell-assisted lipotransfer: supportive use of human adipose-derived cells for soft tissue augmentation with lipoinjection," Tissue Engineering, vol. 12, no. 12, pp. 3375-3382, 2006.

[225] M. Zhu, Z. Zhou, Y. Chen et al., "Supplementation of fat grafts with adipose-derived regenerative cells improves long-term graft retention," Annals of Plastic Surgery, vol. 64, no. 2, pp. 222228, 2010.

[226] S. Bhagavati, "Stem cell based therapy for skeletal muscle diseases," Current Stem Cell Research and Therapy, vol. 3, no. 3, pp. 219-228, 2008.

[227] A. S. de la Garza-Rodea, I. van der Velde-van Dijke, H. Boersma et al., "Myogenic properties of human mesenchymal stem cells derived from three different sources," Cell Transplantation, vol. 21, no. 1, pp. 153-173, 2012.

[228] E. J. Gang, R. Darabi, D. Bosnakovski et al., "Engraftment of mesenchymal stem cells into dystrophin-deficient mice is not accompanied by functional recovery," Experimental Cell Research, vol. 315, no. 15, pp. 2624-2636, 2009.

[229] A. M. Rodriguez, D. Pisani, C. A. Dechesne et al., "Transplantation of a multipotent cell population from human adipose tissue induces dystrophin expression in the immunocompetent $\mathrm{mdx}$ mouse," Journal of Experimental Medicine, vol. 201, no. 9, pp. 1397-1405, 2005. 
[230] S. Goudenege, D. F. Pisani, B. Wdziekonski et al., "Enhancement of myogenic and muscle repair capacities of human adiposederived stem cells with forced expression of MyoD," Molecular Therapy, vol. 17, no. 6, pp. 1064-1072, 2009.

[231] Y. Liu, X. Yan, Z. Sun et al., "Flk-1' adipose-derived mesenchymal stem cells differentiate into skeletal muscle satellite cells and ameliorate muscular dystrophy in MDX Mice," Stem Cells and Development, vol. 16, no. 5, pp. 695-706, 2007.

[232] N. M. Vieira, C. R. Bueno Jr., V. Brandalise et al., "SJL dystrophic mice express a significant amount of human muscle proteins following systemic delivery of human adipose-derived stromal cells without immunosuppression," Stem Cells, vol. 26, no. 9, pp. 2391-2398, 2008.

[233] R. Zhang, G. S. Jack, N. Rao et al., "Nuclear fusion-independent smooth muscle differentiation of human adipose-derived stem cells induced by a smooth muscle environment," Stem Cells, vol. 30, no. 3, pp. 481-490, 2012.

[234] G. Lin, G. Wang, L. Banie et al., "Treatment of stress urinary incontinence with adipose tissue-derived stem cells," Cytotherapy, vol. 12, no. 1, pp. 88-95, 2010.

[235] G. Wu, Y. Song, X. Zheng, and Z. Jiang, "Adipose-derived stromal cell transplantation for treatment of stress urinary incontinence," Tissue and Cell, vol. 43, no. 4, pp. 246-253, 2011.

[236] Z. Zhao, H. Yu, F. Xiao, X. Wang, S. Yang, and S. Li, "Differentiation of adipose-derived stem cells promotes regeneration of smooth muscle for ureteral tissue engineering," Journal of Surgical Research, vol. 178, no. 1, pp. 55-62, 2012.

[237] W. D. Zhu, Y. M. Xu, C. Feng, Q. Fu, L. J. Song, and L. Cui, "Bladder reconstruction with adipose-derived stem cell-seeded bladder acellular matrix grafts improve morphology composition," World Journal of Urology, vol. 28, no. 4, pp. 493-498, 2010.

[238] H. Zhang, X. Qiu, A. W. Shindel et al., "Adipose tissue-derived stem cells ameliorate diabetic bladder dysfunction in a type II diabetic rat model," Stem Cells and Development, vol. 21, no. 9, pp. 1391-1400, 2012.

[239] P. Fotuhi, Y. H. Song, and E. Alt, "Electrophysiological consequence of adipose-derived stem cell transplantation in infarcted porcine myocardium," Europace, vol. 9, no. 12, pp. 1218-1221, 2007.

[240] J. G. Shake, P. J. Gruber, W. A. Baumgartner et al., "Mesenchymal stem cell implantation in a swine myocardial infarct model: engraftment and functional effects," Annals of Thoracic Surgery, vol. 73, no. 6, pp. 1919-1926, 2002.

[241] H. Okura, A. Saga, M. Soeda et al., "Intracoronary artery transplantation of cardiomyoblast-like cells from human adipose tissue-derived multi-lineage progenitor cells improve left ventricular dysfunction and survival in a swine model of chronic myocardial infarction," Biochemical and Biophysical Research Communications, vol. 425, no. 4, pp. 859-865, 2012.

[242] H. Kamihata, H. Matsubara, T. Nishiue et al., "Implantation of bone marrow mononuclear cells into ischemic myocardium enhances collateral perfusion and regional function via side supply of angioblasts, angiogenic ligands, and cytokines," Circulation, vol. 104, no. 9, pp. 1046-1052, 2001.

[243] E. T. H. Yeh, S. Zhang, H. D. Wu, M. Körbling, J. T. Willerson, and Z. Estrov, "Transdifferentiation of human peripheral blood $\mathrm{CD} 34^{+}$-enriched cell population into cardiomyocytes, endothelial cells, and smooth muscle cells in vivo," Circulation, vol. 108, no. 17, pp. 2070-2073, 2003.

[244] J. O. Beitnes, E. Oie, A. Shahdadfar et al., "Intramyocardial injections of human mesenchymal stem cells following acute myocardial infarction modulate scar formation and improve left ventricular function," Cell Transplantation, vol. 21, no. 8, pp. 1697-1709, 2012.

[245] J. Yang, H. Zhang, L. Zhao, Y. Chen, H. Liu, and T. Zhang, "Human adipose tissue-derived stem cells protect impaired cardiomyocytes from hypoxia/reoxygenation injury through hypoxia-induced paracrine mechanism," Cell Biochemistry and Function, vol. 30, no. 6, pp. 505-514, 2012.

[246] B. Léobon, J. Roncalli, C. Joffre et al., "Adipose-derived cardiomyogenic cells: in vitro expansion and functional improvement in a mouse model of myocardial infarction," Cardiovascular Research, vol. 83, no. 4, pp. 757-767, 2009.

[247] M. Mazo, V. Planat-Bénard, G. Abizanda et al., "Transplantation of adipose derived stromal cells is associated with functional improvement in a rat model of chronic myocardial infarction," European Journal of Heart Failure, vol. 10, no. 5, pp. 454-462, 2008.

[248] X. Zhang, H. Wang, X. Ma et al., "Preservation of the cardiac function in infarcted rat hearts by the transplantation of adipose-derived stem cells with injectable fibrin scaffolds," Experimental Biology and Medicine, vol. 235, no. 12, pp. 1505-1515, 2010.

[249] L. Cai, B. H. Johnstone, T. G. Cook et al., "IFATS collection: human adipose tissue-derived stem cells induce angiogenesis and nerve sprouting following myocardial infarction, in conjunction with potent preservation of cardiac function," Stem Cells, vol. 27, no. 1, pp. 230-237, 2009.

[250] M. Gu, P. K. Nguyen, A. S. Lee et al., "Microfluidic single cell analysis show porcine induced pluripotent stem cell-derived endothelial cells improve myocardial function by paracrine activation," Circulation Research, vol. 111, no. 7, pp. 882-893, 2012.

[251] B. M. Strem, M. Zhu, Z. Alfonso et al., "Expression of cardiomyocytic markers on adipose tissue-derived cells in a murine model of acute myocardial injury," Cytotherapy, vol. 7, no. 3, pp. 282-291, 2005.

[252] D. Z. Zhang, L. Y. Gai, H. W. Liu, Q. H. Jin, J. H. Huang, and X. Y. Zhu, "Transplantation of autologous adipose-derived stem cells ameliorates cardiac function in rabbits with myocardial infarction," Chinese Medical Journal, vol. 120, no. 4, pp. 300-307, 2007.

[253] J. J. Yang, Z. Q. Liu, J. M. Zhang et al., "Real-time tracking of adipose tissue-derived stem cells with injectable scaffolds in the infarcted heart," Heart Vessels. In press.

[254] D. H. Kim, C. M. Je, J. Y. Sin, and J. S. Jung, "Effect of partial hepatectomy on in vivo engraftment after intravenous administration of human adipose tissue stromal cells in mouse," Microsurgery, vol. 23, no. 5, pp. 424-431, 2003.

[255] M. Wang, H. Pei, L. Zhang et al., "Hepatogenesis of adiposederived stem cells on poly-lactide-co-glycolide scaffolds: in vitro and in vivo studies," Tissue Engineering C, vol. 16, no. 5, pp. 10411050, 2010.

[256] H. J. Harn, S. Z. Lin, S. H. Hung et al., "Adipose-derived stem cells can abrogate chemical-induced liver fibrosis and facilitate recovery of liver function," Cell Transplantation. In press.

[257] J. C. Ruiz, J. W. Ludlow, S. Sherwood, G. Yu, X. Wu, and J. M. Gimble, "Differentiated human adipose-derived stem cells exhibit hepatogenic capability in vitro and in vivo," Journal of Cellular Physiology, vol. 225, no. 2, pp. 429-436, 2010.

[258] A. Banas, T. Teratani, Y. Yamamoto et al., "IFATS collection: in vivo therapeutic potential of human adipose tissue mesenchymal stem cells after transplantation into mice with liver injury," Stem Cells, vol. 26, no. 10, pp. 2705-2712, 2008. 
[259] L. R. Zhao, W. M. Duan, M. Reyes, C. D. Keene, C. M. Verfaillie, and W. C. Low, "Human bone marrow stem cells exhibit neural phenotypes and ameliorate neurological deficits after grafting into the ischemic brain of rats," Experimental Neurology, vol. 174, no. 1, pp. 11-20, 2002.

[260] K. Satake, J. Lou, and L. G. Lenke, "Migration of mesenchymal stem cells through cerebrospinal fluid into injured spinal cord tissue," Spine, vol. 29, no. 18, pp. 1971-1979, 2004.

[261] Y. C. Yang, B. S. Liu, C. C. Shen, C. H. Lin, M. T. Chiao, and H. C. Cheng, "Transplantation of adipose tissue-derived stem cells for treatment of focal cerebral ischemia," Current Neurovascular Research, vol. 8, no. 1, pp. 1-13, 2011.

[262] S. K. Kang, D. H. Lee, Y. C. Bae, H. K. Kim, S. Y. Baik, and J. S. Jung, "Improvement of neurological deficits by intracerebral transplantation of human adipose tissue-derived stromal cells after cerebral ischemia in rats," Experimental Neurology, vol. 183, no. 2, pp. 355-366, 2003.

[263] S. Leu, Y. C. Lin, C. M. Yuen et al., "Adipose-derived mesenchymal stem cells markedly attenuate brain infarct size and improve neurological function in rats," Journal of Translational Medicine, vol. 8, article 63, 2010.

[264] H. H. Ryu, J. H. Lim, Y. E. Byeon et al., "Functional recovery and neural differentiation after transplantation of allogenic adiposederived stem cells in a canine model of acute spinal cord injury," Journal of Veterinary Science, vol. 10, no. 4, pp. 273-284, 2009.

[265] Y. Wang, Z. Zhao, Z. Ren et al., "Recellularized nerve allografts with differentiated mesenchymal stem cells promote peripheral nerve regeneration," Neuroscience Letters, vol. 514, no. 1, pp. 96101, 2012.

[266] L. Y. Santiago, J. Clavijo-Alvarez, C. Brayfield, J. P. Rubin, and K. G. Marra, "Delivery of adipose-derived precursor cells for peripheral nerve repair," Cell Transplantation, vol. 18, no. 2, pp. 145-158, 2009.

[267] S. S. Park, Y. J. Lee, S. H. Lee et al., "Functional recovery after spinal cord injury in dogs treated with a combination of Matrigel and neural-induced adipose-derived mesenchymal stem cells," Cytotherapy, vol. 14, no. 5, pp. 584-597, 2012.

[268] J. Y. Chung, W. Kim, W. Im et al., "Neuroprotective effects of adipose-derived stem cells against ischemic neuronal damage in the rabbit spinal cord," Journal of the Neurological Sciences, vol. 317, no. 1-2, pp. 40-46, 2012.

[269] K. Tomita, T. Madura, C. Mantovani, and G. Terenghi, "Differentiated adipose-derived stem cells promote myelination and enhance functional recovery in a rat model of chronic denervation," Journal of Neuroscience Research, vol. 90, no. 7, pp. 1392-1402, 2012.

[270] F. Sun, K. Zhou, W. J. Mi, and J. H. Qiu, "Combined use of decellularized allogeneic artery conduits with autologous transdifferentiated adipose-derived stem cells for facial nerve regeneration in rats," Biomaterials, vol. 32, no. 32, pp. 8118-8128, 2011.

[271] G. F. Chi, M. R. Kim, D. W. Kim, M. H. Jiang, and Y. Son, "Schwann cells differentiated from spheroid-forming cells of rat subcutaneous fat tissue myelinate axons in the spinal cord injury," Experimental Neurology, vol. 222, no. 2, pp. 304-317, 2010.

[272] H. Orbay, A. C. Uysal, H. Hyakusoku, and H. Mizuno, "Differentiated and undifferentiated adipose-derived stem cells improve function in rats with peripheral nerve gaps," Journal of Plastic, Reconstructive and Aesthetic Surgery, vol. 65, no. 5, pp. 657-664, 2012.

[273] P. G. di Summa, P. J. Kingham, W. Raffoul, M. Wiberg, G. Terenghi, and D. F. Kalbermatten, "Adipose-derived stem cells enhance peripheral nerve regeneration," Journal of Plastic, Reconstructive and Aesthetic Surgery, vol. 63, no. 9, pp. 15441552, 2010.

[274] H. T. Zhang, H. Y. Cheng, Y. Q. Cai et al., "Comparison of adult neurospheres derived from different origins for treatment of rat spinal cord injury," Neuroscience Letters, vol. 458, no. 3, pp. 116121, 2009.

[275] A. Nakada, S. Fukuda, S. Ichihara et al., "Regeneration of central nervous tissue using a collagen scaffold and adipose-derived stromal cells," Cells Tissues Organs, vol. 190, no. 6, pp. 326-335, 2009.

[276] X. Wei, Z. Du, L. Zhao et al., "IFATS collection: the conditioned media of adipose stromal cells protect against hypoxia-ischemia-induced brain damage in neonatal rats," Stem Cells, vol. 27, no. 2, pp. 478-488, 2009.

[277] X. Wei, L. Zhao, J. Zhong et al., "Adipose stromal cells-secreted neuroprotective media against neuronal apoptosis," Neuroscience Letters, vol. 462, no. 1, pp. 76-79, 2009.

[278] M. Albersen, T. M. Fandel, G. Lin et al., "Injections of adipose tissue-derived stem cells and stem cell lysate improve recovery of erectile function in a rat model of cavernous nerve injury," Journal of Sexual Medicine, vol. 7, no. 10, pp. 3331-3340, 2010.

[279] T. Lopatina, N. Kalinina, M. Karagyaur et al., "Adipose-derived stem cells stimulate regeneration of peripheral nerves: BDNF secreted by these cells promotes nerve healing and axon growth de novo," PLoS ONE, vol. 6, no. 3, Article ID el7899, 2011.

[280] A. J. Reid, M. Sun, M. Wiberg, S. Downes, G. Terenghi, and P. J. Kingham, "Nerve repair with adipose-derived stem cells protects dorsal root ganglia neurons from apoptosis," Neuroscience, vol. 199, pp. 515-522, 2011.

[281] S. Lu, C. Lu, Q. Han et al., "Adipose-derived mesenchymal stem cells protect PC12 cells from glutamate excitotoxicity-induced apoptosis by upregulation of XIAP through PI3-K/Akt activation," Toxicology, vol. 279, no. 1-3, pp. 189-195, 2011.

[282] Y. Zhang, H. Luo, Z. Zhang et al., "A nerve graft constructed with xenogeneic acellular nerve matrix and autologous adiposederived mesenchymal stem cells," Biomaterials, vol. 31, no. 20, pp. 5312-5324, 2010.

[283] T. Suzuki, K. Kobayashi, Y. Tada et al., "Regeneration of the trachea using a bioengineered scaffold with adipose-derived stem cells," Annals of Otology, Rhinology and Laryngology, vol. 117, no. 6, pp. 453-463, 2008.

[284] K. Kobayashi, T. Suzuki, Y. Nomoto et al., "A tissue-engineered trachea derived from a framed collagen scaffold, gingival fibroblasts and adipose-derived stem cells," Biomaterials, vol. 31, no. 18, pp. 4855-4863, 2010.

[285] H. Orbay, Y. Takami, H. Hyakusoku, and H. Mizuno, "Acellular dermal matrix seeded with adipose-derived stem cells as a subcutaneous implant," Aesthetic Plastic Surgery, vol. 35, no. 5, pp. 756-763, 2011.

[286] R. K. Chan, D. O. Zamora, N. L. Wrice et al., "Development of a vascularized skin construct using adipose-derived stem cells from debrided burned skin," Stem Cells International, vol. 2012, Article ID 841203, 11 pages, 2012.

[287] M. A. Shokrgozar, M. Fattahi, S. Bonakdar et al., "Healing potential of mesenchymal stem cells cultured on a collagenbased scaffold for skin regeneration," Iranian Biomedical Journal, vol. 16, no. 2, pp. 68-76, 2012.

[288] A. M. Altman, Y. Yan, N. Matthias et al., "IFATS collection: human adipose-derived stem cells seeded on a silk fibroinchitosan scaffold enhance wound repair in a murine soft tissue injury model," Stem Cells, vol. 27, no. 1, pp. 250-258, 2009. 
[289] S. H. Lee, S. Y. Jin, J. S. Song, K. K. Seo, and K. H. Cho, "Paracrine effects of adipose-derived stem cells on keratinocytes and dermal fibroblasts," Annals of Dermatology, vol. 24, no. 2, pp. 136-143, 2012.

[290] S. Y. Song, J. E. Jung, Y. R. Jeon, K. C. Tark, and D. H. Lew, "Determination of adipose-derived stem cell application on photo-aged fibroblasts, based on paracrine function," Cytotherapy, vol. 13, no. 3, pp. 378-384, 2011.

[291] W. S. Kim, B. S. Park, J. H. Sung et al., "Wound healing effect of adipose-derived stem cells: a critical role of secretory factors on human dermal fibroblasts," Journal of Dermatological Science, vol. 48, no. 1, pp. 15-24, 2007.

[292] K. M. Moon, Y. H. Park, J. S. Lee et al., "The effect of secretory factors of adipose-derived stem cells on human keratinocytes," International Journal of Molecular Sciences, vol. 13, no. 1, pp. 1239-1257, 2012.

[293] W. Lu, J. Yu, Y. Zhang et al., "Mixture of fibroblasts and adipose tissue-derived stem cells can improve epidermal morphogenesis of tissue-engineered skin," Cells Tissues Organs, vol. 195, no. 3, pp. 197-206, 2011.

[294] F. Forcheron, D. Agay, H. Scherthan et al., "Autologous adipocyte derived stem cells favour healing in a minipig model of cutaneous radiation syndrome," PLoS ONE, vol. 7, no. 2, Article ID e31694, 2012.

[295] S. S. Collawn, N. S. Banerjee, J. de la Torre, L. Vasconez, and L. T. Chow, "Adipose-derived stromal cells accelerate wound healing in an organotypic raft culture model," Annals of Plastic Surgery, vol. 68 , no. 5, pp. 501-504, 2012.

[296] H. Jung, H. H. Kim, D. H. Lee, Y. S. Hwang, H. C. Yang, and J. C. Park, "Transforming growth factor- $\beta 1$ in adipose derived stem cells conditioned medium is a dominant paracrine mediator determines hyaluronic acid and collagen expression profile," Cytotechnology, vol. 63, no. 1, pp. 57-66, 2011.

[297] M. H. Moon, S. Y. Kim, Y. J. Kim et al., "Human adipose tissuederived mesenchymal stem cells improve postnatal neovascularization in a mouse model of hindlimb ischemia," Cellular Physiology and Biochemistry, vol. 17, no. 5-6, pp. 279-290, 2006.

[298] M. Sumi, M. Sata, N. Toya, K. Yanaga, T. Ohki, and R. Nagai, "Transplantation of adipose stromal cells, but not mature adipocytes, augments ischemia-induced angiogenesis," Life Sciences, vol. 80, no. 6, pp. 559-565, 2007.

[299] K. Kondo, S. Shintani, R. Shibata et al., "Implantation of adipose-derived regenerative cells enhances ischemia-induced angiogenesis," Arteriosclerosis, Thrombosis, and Vascular Biology, vol. 29, no. 1, pp. 61-66, 2009.

[300] A. Miranville, C. Heeschen, C. Sengenès, C. A. Curat, R. Busse, and A. Bouloumié, "Improvement of postnatal neovascularization by human adipose tissue-derived stem cells," Circulation, vol. 110, no. 3, pp. 349-355, 2004.

[301] Y. J. Koh, B. I. Koh, H. Kim et al., "Stromal vascular fraction from adipose tissue forms profound vascular network through the dynamic reassembly of blood endothelial cells," Arteriosclerosis, Thrombosis, and Vascular Biology, vol. 31, no. 5, pp. 11411150, 2011.

[302] J. P. Steinberg, S. J. Hone, M. R. Geringer, R. D. Galiano, and T. A. Mustoe, "Equivalent effects of topically-delivered adiposederived stem cells and dermal fibroblasts in the ischemic rabbit ear model for chronic wounds," Aesthetic Surgery Journal, vol. 32, no. 4, pp. 504-519, 2012.

[303] E. K. Kim, G. Li, T. J. Lee, and J. P. Hong, “The effect of human adipose-derived stem cells on healing of ischemic wounds in a diabetic nude mouse model," Plastic and Reconstructive Surgery, vol. 128, no. 2, pp. 387-394, 2011.
[304] K. Liu, R. Liu, G. Cao, H. Sun, X. Wang, and S. Wu, "Adiposederived stromal cell autologous transplantation ameliorates pulmonary arterial hypertension induced by shunt flow in rat models," Stem Cells and Development, vol. 20, no. 6, pp. 10011010, 2011.

[305] M. A. Reichenberger, W. Mueller, A. Schafer et al., "Fibrinembedded adipose derived stem cells enhance skin flap surviva," Stem Cell Reviews, vol. 8, no. 3, pp. 844-853, 2012.

[306] W. Gao, X. Qiao, S. Ma, and L. Cui, "Adipose-derived stem cells accelerate neovascularization in ischaemic diabetic skin flap via expression of hypoxia-inducible factor-lalpha," Journal of Cellular and Molecular Medicine, vol. 15, no. 12, pp. 25752585, 2011.

[307] C. Huang, H. Gu, Q. Yu, M. C. Manukyan, J. A. Poynter, and M. Wang, "Sca-1+ cardiac stem cells mediate acute cardioprotection via paracrine factor SDF-1 following myocardial ischemia/ reperfusion," PLoS ONE, vol. 6, no. 12, Article ID e29246, 2011.

[308] X. Jia, X. Xie, G. Feng et al., "Bone marrow-derived cells can acquire renal stem cells properties and ameliorate ischemiareperfusion induced acute renal injury," BMC Nephrology, vol. 13, no. 1, article 105, 2012.

[309] P. Y. Lee, Y. Chien, G. Y. Chiou, C. H. Lin, S. H. Chiou, and D. C. Tarng, "Induced pluripotent stem cells without c-myc attenuate acute kidney injury via down-regulating the signaling of oxidative stress and inflammation in ischemia-reperfusion rats," Cell Transplantation. In press.

[310] G. Z. Pan, Y. Yang, J. Zhang et al., "Bone marrow mesenchymal stem cells ameliorate hepatic ischemia/reperfusion injuries via inactivation of the MEK/ERK signaling pathway in rats," Journal of Surgical Research, vol. 178, no. 2, pp. 935-948, 2012.

[311] M. Mazo, S. Hernandez, and J. J. Gavira, "Treatment of reperfused ischemia with adipose-derived stem cells in a preclinical swine model of myocardial infarction," Cell Transplantation. In press.

[312] C. K. Sun, C. H. Yen, Y. C. Lin et al., "Autologous transplantation of adipose-derived mesenchymal stem cells markedly reduced acute ischemia-reperfusion lung injury in a rodent model," Journal of Translational Medicine, vol. 9, article 118, 2011.

[313] K. Furuichi, H. Shintani, Y. Sakai et al., " Effects of adiposederived mesenchymal cells on ischemia-reperfusion injury in kidney," Clinical and Experimental Nephrology, vol. 16, no. 5, pp. 678-689, 2012.

[314] Y. T. Chen, C. K. Sun, Y. C. Lin et al., "Adipose-derived mesenchymal stem cell protects kidneys against ischemia-reperfusion injury through suppressing oxidative stress and inflammatory reaction," Journal of Translational Medicine, vol. 9, article 51, 2011.

[315] C. Nie, D. Yang, J. Xu, Z. Si, X. Jin, and J. Zhang, "Locally administered adipose-derived stem cells accelerate wound healing through differentiation and vasculogenesis," Cell Transplantation, vol. 20, no. 2, pp. 205-216, 2011.

[316] H. Froehlich, R. Gulati, B. Boilson et al., "Carotid repair using autologous adipose-derived endothelial cells," Stroke, vol. 40, no. 5, pp. 1886-1891, 2009.

[317] D. O. Traktuev, D. N. Prater, S. Merfeld-Clauss et al., "Robust functional vascular network formation in vivo by cooperation of adipose progenitor and endothelial cells," Circulation Research, vol. 104, no. 12, pp. 1410-1420, 2009.

[318] J. Rehman, D. Traktuev, J. Li et al., "Secretion of angiogenic and antiapoptotic factors by human adipose stromal cells," Circulation, vol. 109, no. 10, pp. 1292-1298, 2004. 
[319] S. H. Bhang, S. W. Cho, W. G. La et al., "Angiogenesis in ischemic tissue produced by spheroid grafting of human adipose-derived stromal cells," Biomaterials, vol. 32, no. 11, pp. 2734-2747, 2011.

[320] L. Sheng, M. Yang, and H. Li, "Transplantation of adipose stromal cells promotes neovascularization of random skin flaps," Tohoku Journal of Experimental Medicine, vol. 224, no. 3, pp. 229-234, 2011.

[321] L. Cai, B. H. Johnstone, T. G. Cook et al., "Suppression of hepatocyte growth factor production impairs the ability of adiposederived stem cells to promote ischemic tissue revascularization," Stem Cells, vol. 25, no. 12, pp. 3234-3243, 2007.

[322] D. J. Dumont, G. H. Fong, M. C. Puri, G. Gradwohl, K. Alitalo, and M. L. Breitman, "Vascularization of the mouse embryo: a study of flk-1, tek, tie, and vascular endothelial growth factor expression during development," Developmental Dynamics, vol. 203, no. 1, pp. 80-92, 1995.

[323] L. B. Jakeman, M. Armanini, H. S. Phillips, and N. Ferrara, "Developmental expression of binding sites and messenger ribonucleic acid for vascular endothelial growth factor suggests a role for this protein in vasculogenesis and angiogenesis," Endocrinology, vol. 133, no. 2, pp. 848-859, 1993.

[324] A. Tufro, V. F. Norwood, R. M. Carey, and R. A. Gomez, "Vascular endothelial growth factor induces nephrogenesis and vasculogenesis," Journal of the American Society of Nephrology, vol. 10, no. 10, pp. 2125-2134, 1999.

[325] N. Grewal, L. Yacomotti, V. Melkonyan, M. Massey, J. P. Bradley, and P. A. Zuk, "Freezing adipose tissue grafts may damage their ability to integrate into the host," Connective Tissue Research, vol. 50, no. 1, pp. 14-28, 2009.

[326] K. Rubina, N. Kalinina, A. Efimenko et al., "Adipose stromal cells stimulate angiogenesis via promoting progenitor cell differentiation, secretion of angiogenic factors, and enhancing vessel maturation," Tissue Engineering, vol. 15, no. 8, pp. 2039-2050, 2009.

[327] A. Zografou, C. Tsigris, O. Papadopoulos et al., "Improvement of skin-graft survival after autologous transplantation of adipose-derived stem cells in rats," Journal of Plastic, Reconstructive and Aesthetic Surgery, vol. 64, no. 12, pp. 1647-1656, 2011.

[328] K. H. Tse, P. J. Kingham, L. N. Novikov, and M. Wiberg, "Adipose tissue and bone marrow-derived stem cells react similarly in an ischaemia-like microenvironment," Journal of Tissue Engineering and Regenerative Medicine, vol. 6, no. 6, pp. 473-485, 2011.

[329] T. Ma, H. Liu, W. Chen et al., "Implanted adipose-derived stem cells attenuate small-for-size liver graft injury by secretion of VEGF in rats," American Journal of Transplantation, vol. 12, no. 3, pp. 620-629, 2012.

[330] S. H. Song, M. O. Lee, J. S. Lee et al., "Genetic modification of human adipose-derived stem cells for promoting wound healing," Journal of Dermatological Science, vol. 66, no. 2, pp. 98-107, 2012.

[331] M. Ii, M. Horii, A. Yokoyama et al., "Synergistic effect of adipose-derived stem cell therapy and bone marrow progenitor recruitment in ischemic heart," Laboratory Investigation, vol. 91, no. 4, pp. 539-552, 2011.

[332] M. D. Nicola, C. Carlo-Stella, M. Magni et al., "Human bone marrow stromal cells suppress T-lymphocyte proliferation induced by cellular or nonspecific mitogenic stimuli," Blood, vol. 99, no. 10, pp. 3838-3843, 2002.

[333] M. Krampera, S. Glennie, J. Dyson et al., "Bone marrow mesenchymal stem cells inhibit the response of naive and memory antigen-specific T cells to their cognate peptide," Blood, vol. 101, no. 9, pp. 3722-3729, 2003.
[334] F. Djouad, P. Plence, C. Bony et al., "Immunosuppressive effect of mesenchymal stem cells favors tumor growth in allogeneic animals," Blood, vol. 102, no. 10, pp. 3837-3844, 2003.

[335] L. Cui, S. Yin, W. Liu, N. Li, W. Zhang, and Y. Cao, "Expanded adipose-derived stem cells suppress mixed lymphocyte reaction by secretion of prostaglandin E2," Tissue Engineering, vol. 13, no. 6, pp. 1185-1195, 2007.

[336] B. Puissant, C. Barreau, P. Bourin et al., "Immunomodulatory effect of human adipose tissue-derived adult stem cells: comparison with bone marrow mesenchymal stem cells," British Journal of Haematology, vol. 129, no. 1, pp. 118-129, 2005.

[337] S. Wolbank, A. Peterbauer, M. Fahrner et al., "Dose-dependent immunomodulatory effect of human stem cells from amniotic membrane: a comparison with human mesenchymal stem cells from adipose tissue," Tissue Engineering, vol. 13, no. 6, pp. 11731183, 2007.

[338] K. H. Yoo, I. K. Jang, M. W. Lee et al., "Comparison of immunomodulatory properties of mesenchymal stem cells derived from adult human tissues," Cellular Immunology, vol. 259, no. 2, pp. 150-156, 2009.

[339] W. Peng, T. Gao, Z. L. Yang et al., "Adipose-derived stem cells induced dendritic cells undergo tolerance and inhibit Th1 polarization," Cellular Immunology, vol. 278, no. 1-2, pp. 152-157, 2012.

[340] K. S. Schweitzer, B. H. Johnstone, J. Garrison et al., "Adipose stem cell treatment in mice attenuates lung and systemic injury induced by cigarette smoking," American Journal of Respiratory and Critical Care Medicine, vol. 183, no. 2, pp. 215-225, 2011.

[341] K. S. Cho and H. J. Roh, "Immunomodulatory effects of adipose-derived stem cells in airway allergic diseases," Current Stem Cell Research and Therapy, vol. 5, no. 2, pp. 111-115, 2010.

[342] J. M. Kim, S. T. Lee, K. Chu et al., "Systemic transplantation of human adipose stem cells attenuated cerebral inflammation and degeneration in a hemorrhagic stroke model," Brain Research, vol. 1183, no. 1, pp. 43-50, 2007.

[343] M. Ter Huurne, R. Schelbergen, R. Blattes et al., "Intra-articular injection of adipose stem cells cause anti-inflammatory and chondro protective effects in an experimental model of osteoarthritis," Arthritis and Rheumatism, vol. 64, no. 11, pp. 3604-3613, 2012.

[344] N. L. Payne, A. Dantanarayana, G. Sun et al., "Early intervention with gene-modified mesenchymal stem cells overexpressing interleukin-4 enhances anti-inflammatory responses and functional recovery in experimental autoimmune demyelination," Cell Adhesion \& Migration, vol. 6, no. 3, pp. 179-189, 2012.

[345] Y. R. Kuo, C. C. Chen, S. Goto et al., "Modulation of immune response and $\mathrm{T}$-cell regulation by donor adipose-derived stem cells in a rodent hind-limb allotransplant model," Plastic and Reconstructive Surgery, vol. 128, no. 6, pp. 661e-672e, 2011.

[346] M. A. González, E. González-Rey, L. Rico, D. Büscher, and M. Delgado, "Treatment of experimental arthritis by inducing immune tolerance with human adipose-derived mesenchymal stem cells," Arthritis and Rheumatism, vol. 60, no. 4, pp. 10061019, 2009.

[347] E. Gonzalez-Rey, M. A. Gonzalez, N. Varela et al., "Human adipose-derived mesenchymal stem cells reduce inflammatory and $\mathrm{T}$ cell responses and induce regulatory $\mathrm{T}$ cells in vitro in rheumatoid arthritis," Annals of the Rheumatic Diseases, vol. 69, no. 1, pp. 241-248, 2010.

[348] B. Zhou, J. Yuan, Y. Zhou et al., "Administering human adiposederived mesenchymal stem cells to prevent and treat experimental arthritis," Clinical Immunology, vol. 141, no. 3, pp. 328337, 2011. 
[349] Y. Zhou, J. Yuan, B. Zhou et al., "The therapeutic efficacy of human adipose tissue-derived mesenchymal stem cells on experimental autoimmune hearing loss in mice," Immunology, vol. 133, no. 1, pp. 133-140, 2011.

[350] K. Lai, K. Zeng, F. Zeng, J. Wei, and G. Tan, “Allogeneic adiposederived stem cells suppress Th17 lymphocytes in patients with active lupus in vitro," Acta Biochimica et Biophysica Sinica, vol. 43, no. 10, pp. 805-812, 2011.

[351] Y. Y. Hyun, I. O. Kim, M. H. Kim et al., "Adipose-derived stem cells improve renal function in a mouse model of IgA nephropathy," Cell Transplantation. In press.

[352] C. Donizetti-Oliveira, P. Semedo, M. Burgos-Silva et al., "Adipose tissue-derived stem cell treatment prevents renal disease progression," Cell Transplantation, vol. 21, no. 8, pp. 1727-1741, 2012.

[353] C. H. Pinheiro, J. C. de Queiroz, L. Guimaraes-Ferreira et al., "Local injections of adipose-derived mesenchymal stem cells modulate inflammation and increase angiogenesis ameliorating the dystrophic phenotype in dystrophin-deficient skeletal muscle," Stem Cell Reviews, vol. 8, no. 2, pp. 363-374, 2012.

[354] M. A. González, E. Gonzalez-Rey, L. Rico, D. Büscher, and M. Delgado, "Adipose-derived mesenchymal stem cells alleviate experimental colitis by inhibiting inflammatory and autoimmune responses," Gastroenterology, vol. 136, no. 3, pp. 978-989, 2009.

[355] C. D. Wan, R. Cheng, H. B. Wang, and T. Liu, "Immunomodulatory effects of mesenchymal stem cells derived from adipose tissues in a rat orthotopic liver transplantation model," Нераtobiliary and Pancreatic Diseases International, vol. 7, no. 1, pp. 29-33, 2008.

[356] M. Najar, G. Raicevic, H. I. Boufker et al., "Adipose-tissuederived and Wharton's jelly-derived mesenchymal stromal cells suppress lymphocyte responses by secreting leukemia inhibitory factor," Tissue Engineering, vol. 16, no. 11, pp. 3537-3546, 2010.

[357] F. Djouad, L. M. Charbonnier, C. Bouffi et al., "Mesenchymal stem cells inhibit the differentiation of dendritic cells through an interleukin-6-dependent mechanism," Stem Cells, vol. 25, no. 8, pp. 2025-2032, 2007.

[358] D. García-Olmo, M. García-Arranz, L. Gómez García et al., "Autologous stem cell transplantation for treatment of rectovaginal fistula in perinatal Crohn's disease: a new cell-based therapy," International Journal of Colorectal Disease, vol. 18, no. 5, pp. 451-454, 2003.

[359] D. García-Olmo, M. García-Arranz, D. Herreros, I. Pascual, C. Peiro, and J. A. Rodríguez-Montes, "A phase I clinical trial of the treatment of Crohn's fistula by adipose mesenchymal stem cell transplantation," Diseases of the Colon and Rectum, vol. 48, no. 7, pp. 1416-1423, 2005.

[360] D. García-Olmo, D. Herreros, P. De-La-Quintana et al., "Adipose-derived stem cells in Crohn's rectovaginal fistula," Case Reports in Medicine, vol. 2010, Article ID 961758, 3 pages, 2010.

[361] D. Garcia-Olmo, D. Herreros, I. Pascual et al., "Expanded adipose-derived stem cells for the treatment of complex perianal fistula: a phase II clinical trial," Diseases of the Colon and Rectum, vol. 52, no. 1, pp. 79-86, 2009.

[362] H. Guadalajara, D. Herreros, P. De-La-Quintana, J. Trebol, M. Garcia-Arranz, and D. Garcia-Olmo, "Long-term follow-up of patients undergoing adipose-derived adult stem cell administration to treat complex perianal fistulas," International Journal of Colorectal Disease, vol. 27, no. 5, pp. 595-600, 2012.

[363] K. H. Song, "New techniques for treating an anal fistula," Journal of the Korean Society of Coloproctology, vol. 28, no. 1, pp. 7-12, 2012.
[364] D. Garcia-Olmo, D. Herreros, M. Pascual et al., "Treatment of enterocutaneous fistula in Crohn's disease with adipose-derived stem cells: a comparison of protocols with and without cell expansion," International Journal of Colorectal Disease, vol. 24, no. 1, pp. 27-30, 2009.

[365] M. D. Herreros, M. Garcia-Arranz, H. Guadalajara, P. DeLa-Quintana, and D. Garcia-Olmo, "Autologous expanded adipose-derived stem cells for the treatment of complex cryptoglandular perianal fistulas: a phase III randomized clinical trial (FATT 1: fistula advanced therapy trial 1) and long-term evaluation," Diseases of the Colon \& Rectum, vol. 55, no. 7, pp. 762-772, 2012.

[366] N. H. Riordan, T. E. Ichim, W. P. Min et al., "Non-expanded adipose stromal vascular fraction cell therapy for multiple sclerosis," Journal of Translational Medicine, vol. 7, article 29, 2009.

[367] J. C. Ra, S. K. Kang, I. S. Shin et al., "Stem cell treatment for patients with autoimmune disease by systemic infusion of culture-expanded autologous adipose tissue derived mesenchymal stem cells," Journal of Translational Medicine, vol. 9, article 181, 2011.

[368] B. Fang, Y. Song, L. Liao, Y. Zhang, and R. C. Zhao, "Favorable response to human adipose tissue-derived mesenchymal stem cells in steroid-refractory acute graft-versus-host disease," Transplantation Proceedings, vol. 39, no. 10, pp. 3358-3362, 2007.

[369] B. Fang, Y. Song, Q. Lin et al., "Human adipose tissue-derived mesenchymal stromal cells as salvage therapy for treatment of severe refractory acute graft-versus-host disease in two children," Pediatric Transplantation, vol. 11, no. 7, pp. 814-817, 2007.

[370] B. Fang, Y. P. Song, L. M. Liao, Q. Han, and R. C. Zhao, "Treatment of severe therapy-resistant acute graft-versus-host disease with human adipose tissue-derived mesenchymal stem cells," Bone Marrow Transplantation, vol. 38, no. 5, pp. 389-390, 2006.

[371] R. Yañez, M. L. Lamana, J. García-Castro, I. Colmenero, M. Ramírez, and J. A. Bueren, "Adipose tissue-derived mesenchymal stem cells have in vivo immunosuppressive properties applicable for the control of the graft-versus-host disease," Stem Cells, vol. 24, no. 11, pp. 2582-2591, 2006.

[372] V. Sergeevicheva, I. Kruchkova, E. Chernykh et al., "Rapid recovery from Chronic PRCA by MSC infusion in patient after major ABO-mismatched alloSCT," Case Reports in Medicine, vol. 2012, Article ID 862721, 4 pages, 2012.

[373] A. Hasharoni, Y. Zilberman, G. Turgeman, G. A. Helm, M. Liebergall, and D. Gazit, "Murine spinal fusion induced by engineered mesenchymal stem cells that conditionally express bone morphogenetic protein-2," Journal of Neurosurgery. Spine, vol. 3, no. 1, pp. 47-52, 2005.

[374] S. C. N. Chang, H. Chuang, Y. R. Chen et al., "Cranial repair using BMP-2 gene engineered bone marrow stromal cells," Journal of Surgical Research, vol. 119, no. 1, pp. 85-91, 2004.

[375] X. Guo, Q. Zheng, I. Kulbatski et al., "Bone regeneration with active angiogenesis by basic fibroblast growth factor gene transfected mesenchymal stem cells seeded on porous $\beta$-TCP ceramic scaffolds," Biomedical Materials, vol. 1, no. 3, pp. 93-99, 2006.

[376] M. Studeny, F. C. Marini, R. E. Champlin, C. Zompetta, I. J. Fidler, and M. Andreeff, "Bone marrow-derived mesenchymal stem cells as vehicles for interferon- $\beta$ delivery into tumors," Cancer Research, vol. 62, no. 13, pp. 3603-3608, 2002.

[377] X. C. Chen, R. Wang, X. Zhao et al., "Prophylaxis against carcinogenesis in three kinds of unestablished tumor models via 
IL12-gene-engineered MSCs," Carcinogenesis, vol. 27, no. 12, pp. 2434-2441, 2006.

[378] L. Lin, X. Fu, X. Zhang et al., "Rat adipose-derived stromal cells expressing BMP4 induce ectopic bone formation in vitro and in vivo," Acta Pharmacologica Sinica, vol. 27, no. 12, pp. 1608-1615, 2006.

[379] J. L. Dragoo, J. Y. Choi, J. R. Lieberman et al., "Bone induction by BMP-2 transduced stem cells derived from human fat," Journal of Orthopaedic Research, vol. 21, no. 4, pp. 622-629, 2003.

[380] W. K. Hsu, J. C. Wang, N. Q. Liu et al., "Stem cells from human fat as cellular delivery vehicles in an athymic rat posterolateral spine fusion model," Journal of Bone and Joint Surgery, vol. 90, no. 5, pp. 1043-1052, 2008.

[381] B. O. Diekman, B. T. Estes, and F. Guilak, "The effects of BMP6 overexpression on adipose stem cell chondrogenesis: interactions with dexamethasone and exogenous growth factors," Journal of Biomedical Materials Research, vol. 93, no. 3, pp. 9941003, 2010.

[382] X. B. Jin, Y. S. Sun, K. Zhang et al., "Tissue engineered cartilage from hTGF $\beta 2$ transduced human adipose derived stem cells seeded in PLGA/alginate compound in vitro and in vivo," Journal of Biomedical Materials Research A, vol. 86, no. 4, pp. 1077-1087, 2008.

[383] E. Jabbarzadeh, T. Starnes, Y. M. Khan et al., "Induction of angiogenesis in tissue-engineered scaffolds designed for bone repair: a combined gene therapy-cell transplantation approach," Proceedings of the National Academy of Sciences of the United States of America, vol. 105, no. 32, pp. 11099-11104, 2008.

[384] F. Lu, J. Li, J. Gao et al., "Improvement of the survival of human autologous fat transplantation by using VEGF-transfected adipose-derived stem cells," Plastic and Reconstructive Surgery, vol. 124, no. 5, pp. 1437-1446, 2009.

[385] D. T. Josiah, D. Zhu, F. Dreher, J. Olson, G. McFadden, and H. Caldas, "Adipose-derived stem cells as therapeutic delivery vehicles of an oncolytic virus for glioblastoma," Molecular Therapy, vol. 18, no. 2, pp. 377-385, 2010.

[386] G. Grisendi, R. Bussolari, L. Cafarelli et al., "Adipose-derived mesenchymal stem cells as stable source of tumor necrosis factor-related apoptosis-inducing ligand delivery for cancer therapy," Cancer Research, vol. 70, no. 9, pp. 3718-3729, 2010.

[387] N. Sun, N. J. Panetta, D. M. Gupta et al., "Feeder-free derivation of induced pluripotent stem cells from adult human adipose stem cells," Proceedings of the National Academy of Sciences of the United States of America, vol. 106, no. 37, pp. 15720-15725, 2009.

[388] K. Takahashi and S. Yamanaka, "Induction of pluripotent stem cells from mouse embryonic and adult fibroblast cultures by defined factors," Cell, vol. 126, no. 4, pp. 663-676, 2006.

[389] T. Aoki, H. Ohnishi, Y. Oda et al., "Generation of induced pluripotent stem cells from human adipose-derived stem cells without c-MYC," Tissue Engineering A, vol. 16, no. 7, pp. 21972206, 2010.

[390] H. Shimada, Y. Hashimoto, A. Nakada, K. Shigeno, and T. Nakamura, "Accelerated generation of human induced pluripotent stem cells with retroviral transduction and chemical inhibitors under physiological hypoxia," Biochemical and Biophysical Research Communications, vol. 417, no. 2, pp. 659-664, 2012.

[391] H. Ohnishi, Y. Oda, T. Aoki et al., "A comparative study of induced pluripotent stem cells generated from frozen, stocked bone marrow- and adipose tissue-derived mesenchymal stem cells," Journal of Tissue Engineering and Regenerative Medicine, vol. 6, no. 4, pp. 261-271, 2012.
[392] P. A. Tat, H. Sumer, K. L. Jones, K. Upton, and P. J. Verma, “The efficient generation of induced pluripotent stem (iPS) cells from adult mouse adipose tissue-derived and neural stem cells," Cell Transplantation, vol. 19, no. 5, pp. 525-536, 2010.

[393] M. Gu, P. K. Nguyen, A. S. Lee et al., "Microfluidic singlecell analysis shows that porcine induced pluripotent stem cellderived endothelial cells improve myocardial function by paracrine activation," Circulation Research, vol. 111, no. 7, pp. 882893, 2012.

[394] C. E. Pasi, A. Dereli-Öz, S. Negrini et al., "Genomic instability in induced stem cells," Cell Death and Differentiation, vol. 18, no. 5, pp. 745-753, 2011.

[395] J. F. Shen, A. Sugawara, J. Yamashita, H. Ogura, and S. Sato, "Dedifferentiated fat cells: an alternative source of adult multipotent cells from the adipose tissues," International Journal of Oral Science, vol. 3, no. 3, pp. 117-124, 2011.

[396] T. Matsumoto, K. Kano, D. Kondo et al., "Mature adipocytederived dedifferentiated fat cells exhibit multilineage potential," Journal of Cellular Physiology, vol. 215, no. 1, pp. 210-222, 2008.

[397] Q. Gao, L. Zhao, Z. Song, and G. Yang, "Expression pattern of embryonic stem cell markers in DFAT cells and ADSCs," Molecular Biology Reports, vol. 39, no. 5, pp. 5791-5804, 2012.

[398] A. Poloni, G. Maurizi, P. Leoni et al., "Human dedifferentiated adipocytes show similar properties to bone marrow-derived mesenchymal stem cells," Stem Cells, vol. 30, no. 5, pp. 965-974, 2012.

[399] Y. Oki, S. Watanabe, T. Endo, and K. Kano, "Mature adipocytederived dedifferentiated fat cells can trans-differentiate into osteoblasts in vitro and in vivo only by all-trans retinoic acid," Cell Structure and Function, vol. 33, no. 2, pp. 211-222, 2008.

[400] N. Kishimoto, Y. Momota, Y. Hashimoto, K. Ando, T. Omasa, and J. Kotani, "Dedifferentiated fat cells differentiate into osteoblasts in titanium fiber mesh," Cytotechnology, vol. 65, no. 1, pp. 15-22, 2013.

[401] S. S. Tholpady, C. Aojanepong, R. Llull et al., "The cellular plasticity of human adipocytes," Annals of Plastic Surgery, vol. 54, no. 6, pp. 651-656, 2005.

[402] M. Jumabay, T. Matsumoto, S. I. Yokoyama et al., "Dedifferentiated fat cells convert to cardiomyocyte phenotype and repair infarcted cardiac tissue in rats," Journal of Molecular and Cellular Cardiology, vol. 47, no. 5, pp. 565-575, 2009.

[403] D. Obinata, T. Matsumoto, Y. Ikado et al., "Transplantation of mature adipocyte-derived dedifferentiated fat (DFAT) cells improves urethral sphincter contractility in a rat model," International Journal of Urology, vol. 18, no. 11, pp. 827-834, 2011.

[404] T. Sakuma, T. Matsumoto, K. Kano et al., "Mature, adipocyte derived, dedifferentiated fat cells can differentiate into smooth muscle-like cells and contribute to bladder tissue regeneration," Journal of Urology, vol. 182, no. 1, pp. 355-365, 2009.

[405] P. Li, J. Estrada, F. Zhang, S. K. Waghmare, and B. Mir, "Isolation, characterization, and nuclear reprogramming of cell lines derived from porcine adult liver and fat," Cellular Reprogramming, vol. 12, no. 5, pp. 599-607, 2010.

[406] R. Tomii, M. Kurome, T. Ochiai et al., "Production of cloned pigs by nuclear transfer of preadipocytes established from adult mature adipocytes," Cloning and Stem Cells, vol. 7, no. 4, pp. 279-288, 2005.

[407] E. S. Jun, T. H. Lee, H. H. Cho, S. Y. Suh, and J. S. Jung, "Expression of telomerase extends longevity and enhances differentiation in human adipose tissue-derived stromal cells," Cellular Physiology and Biochemistry, vol. 14, no. 4-6, pp. 261-268, 2004. 
[408] S. Wolbank, G. Stadler, A. Peterbauer et al., "Telomerase immortalized human amnion- and adipose-derived mesenchymal stem cells: maintenance of differentiation and immunomodulatory characteristics," Tissue Engineering A, vol. 15, no. 7, pp. 1843-1854, 2009.

[409] T. Georgiev-Hristov, M. Garcia-Arranz, I. Garcia-Gomez et al., "Sutures enriched with adipose-derived stem cells decrease the local acute inflammation after tracheal anastomosis in a murine model," European Journal Cardio-Thoracic Surgery, vol. 42, no. 3, pp. e40-e47, 2012.

[410] R. W. Bonvillain, S. Danchuk, D. E. Sullivan et al., "A nonhuman primate model of lung regeneration: detergent-mediated decellularization and initial in vitro recellularization with mesenchymal stem cells," Tissue Engineering A. In press.

[411] T. Martinello, I. Bronzini, A. Volpin et al., "Successful recellularization of human tendon scaffolds using adipose-derived mesenchymal stem cells and collagen gel," Journal of Tissue Engineering and Regenerative Medicine. In press. 


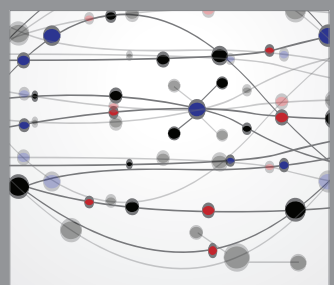

The Scientific World Journal
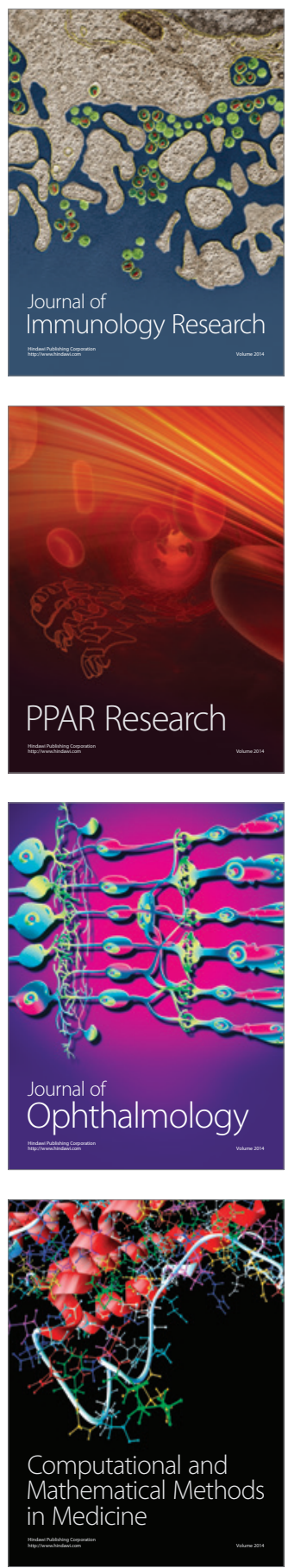

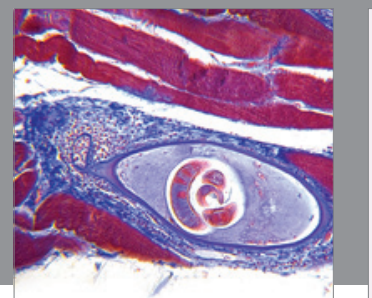

Gastroenterology

Research and Practice
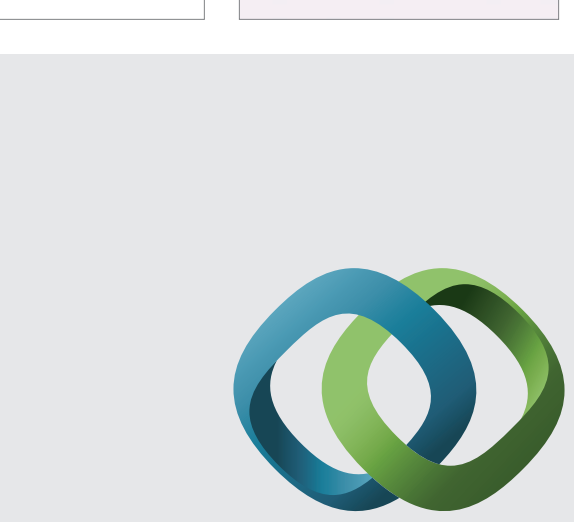

\section{Hindawi}

Submit your manuscripts at

http://www.hindawi.com
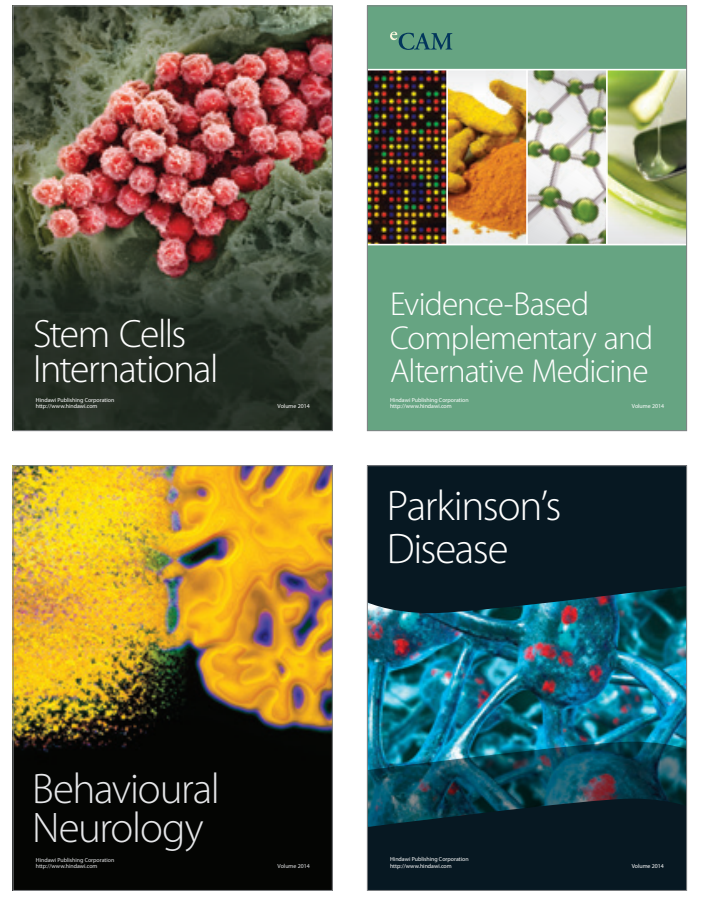
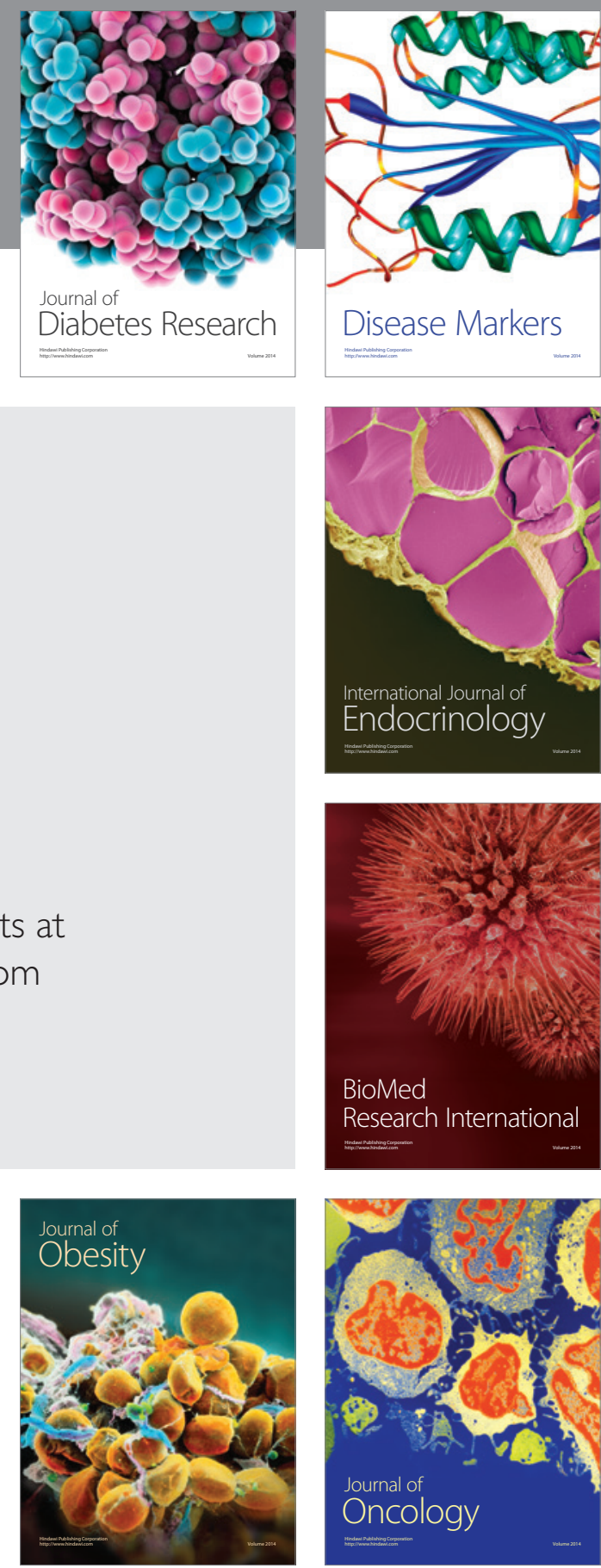

Disease Markers
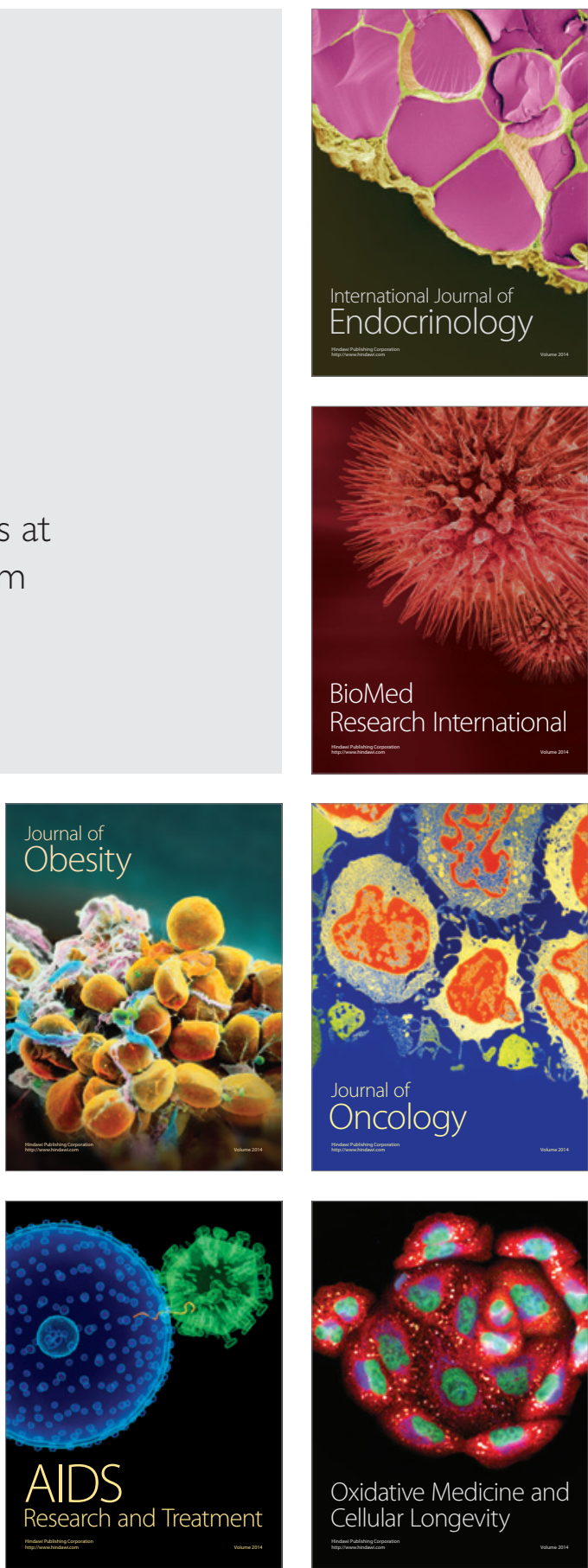